\title{
Greater Sage-Grouse Habitat Use and Population Demographics at the Simpson Ridge Wind Resource Area, Carbon County, Wyoming
}

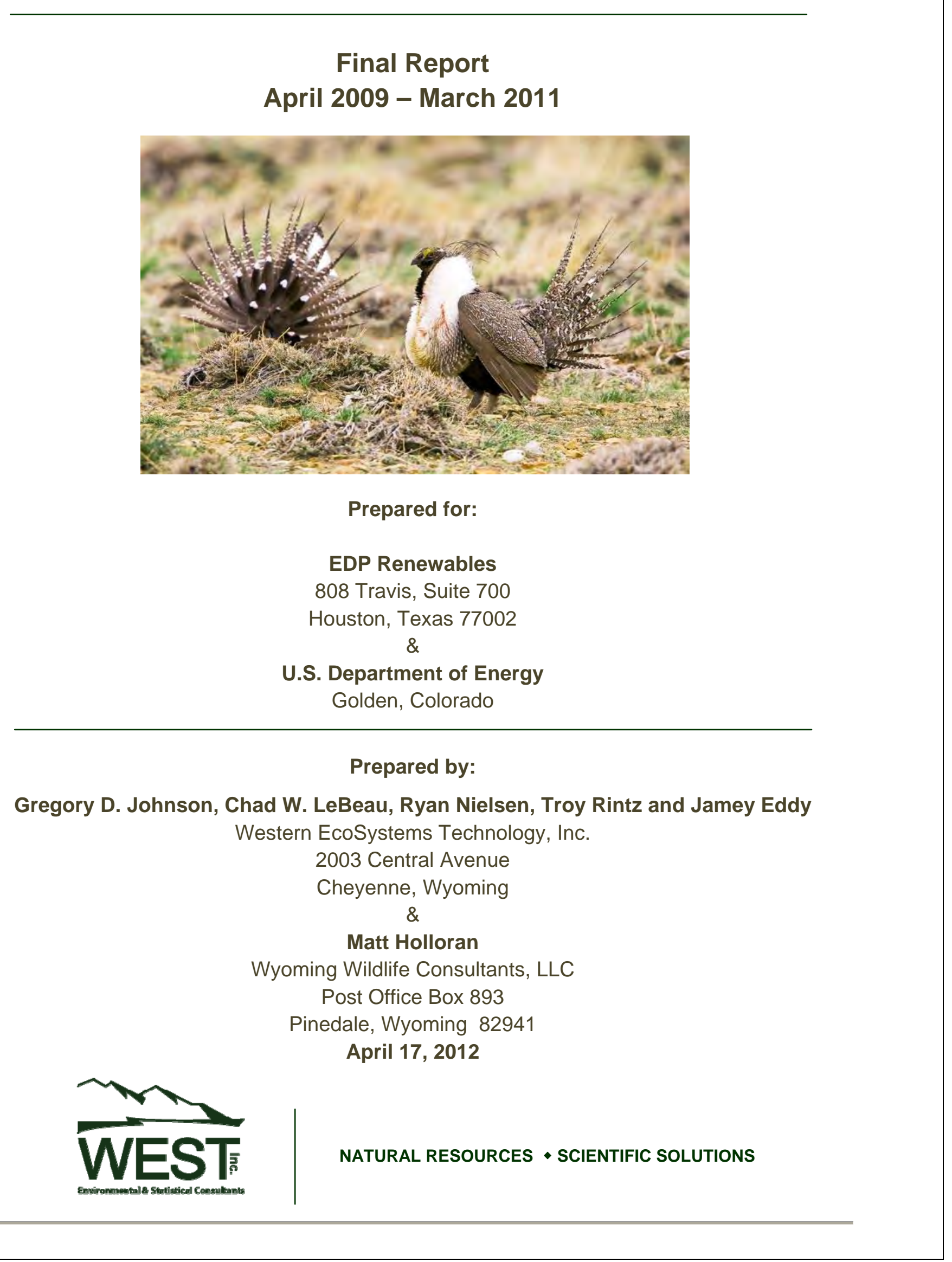




\section{EXECUTIVE SUMMARY}

EDP Renewables (formerly Horizon Wind Energy) has proposed a wind-energy facility in Carbon County, Wyoming. The Simpson Ridge Wind Resource Area (SRWRA) provides habitat for greater sage-grouse, a federal candidate species considered warranted but precluded for listing under the Endangered Species Act. The objectives of this study included 1) Evaluate and determine the functionality and viability of greater sage-grouse habitat within the influence of the proposed Simpson Ridge wind energy development project; and 2) Determine the population impacts of the wind energy project on greater sage-grouse within the influence of the project.

This study was conducted in an area with two proposed wind energy facilities and one existing wind-energy facility. Our general approach was to compare greater sage-grouse habitat selection and demographics on proposed wind energy development areas pre versus postconstruction of the wind energy facilities to determine if wind-energy facilities influence grouse distributions or population growth. The first two years of study were designed to collect data on greater sage-grouse populations in and near the SRWRA necessary to determine pre-treatment seasonally selected habitats (e.g., nesting areas, brood-rearing areas, lek visitation, summer habitat, and winter habitat) and population-level vital rates (e.g., productivity and survival). The presence of an existing wind energy facility in the project area allowed us to obtain some information on initial sage-grouse response to wind turbines the first two years following construction. To our knowledge these are the first quantitative data on sage-grouse response to an existing wind energy development. The purpose of this report is to present results of the first two full years of data collected from April 1, 2009 through March 30, 2011.

This study was selected for continued funding by the National Wind Coordinating Collaborative Sage-Grouse Collaborative (NWCC-SGC) and has been ongoing since March 30, 2011; however, the focus of the study switched from collecting pre-construction data for the SRWRA to collecting post-construction data for the existing 79-turbine PacifiCorp Seven Mile Hill wind energy facility. Future reports summarizing results of this research will be distributed through the NWCC-SGC.

The SRWRA encompasses 28,600.92 acres in Carbon County, Wyoming, between the towns of Hanna and Medicine Bow, and south of US Highway 30. The SRWRA contains numerous ridges interspersed with rolling to hilly plains. Elevations range from $6,700-7,840$ feet above sea level. The SRWRA is situated near the base of the Snowy Range Mountains to the south, and lies south of the Shirley Basin. Climate is classified as a semiarid, cold desert with mean annual precipitation of 12 inches (30.5 centimeters [cm]). The SRWRA is almost entirely (96.7\%) comprised of scrub-shrub, with the dominant shrub being Wyoming big sagebrush. Grassland composes an additional $1.9 \%$ of the study area. All other habitat types each compose less than $1 \%$ of the area individually. Two other WRAs are located in close proximity to the SRWRA. The PacifiCorp Seven Mile Hill (SMH) project is located immediately adjacent to and north of the SRWRA. The SMH project was completed at the end of December 2008 and has 79 GE 1.5MW wind turbines. Just east of the SMH site, and northeast of the SRWRA, is the proposed 
Iberdrola Renewables Pine Draw WRA (PDWRA). Due to high densities of breeding greater sage-grouse, most of the study area was within the area originally mapped by the State of Wyoming as a greater sage-grouse "Core Population Area." However, in the last update to the core population area map (version 3), both the SMH and PDWRA were excluded from the core area to minimize conflicts with existing and planned wind energy development; the SRWRA has remained in the sage-grouse core area.

To investigate population trends through time, we determined the distribution and numbers of males using active leks throughout the study area, which was defined as an approximate 4-mile radius buffer around the SRWRA. Over the 2-year study, 116 female greater sage-grouse were captured by spotlighting and use of hoop nets on roosts surrounding leks during the breeding period. Captured birds were aged, weighed, and fitted with a necklace-mounted radio transmitter equipped with a mortality sensor. Radio marked birds were located anywhere from twice a week to once a month, depending on season. All radio-locations were classified to season, which we defined as breeding, nesting, brood-rearing, summer, fall, or winter.

We developed a suite of predictor variables used to predict success of fitness parameters and relative probability of habitat selection within both the SRWRA and SMH study areas. Anthropogenic features included paved highways, overhead transmission lines, wind turbines and turbine access roads. Environmental variables included vegetation and topography features within both study areas. Home ranges were estimated using a kernel density estimator. We developed resource selection functions (RSF) to estimate probability of selection within the SRWRA and SMH. Binary logistic regression was used to estimate RSF's within both study areas to identify the relative probability of selection as a function of environmental and infrastructure variables.

Fourteen active greater sage-grouse leks were documented during lek surveys in both study areas. The total number of males counted on these leks was 513 in 2008, 464 in 2009, and 312 in 2010; mean lek size during these three years decreased from 37 in 2008 to 22 in 2010 . Four leks located $0.61,1.3,1.4$ and $2.5 \mathrm{~km}$ from the nearest wind turbine remained active throughout the study, but the total number of males counted on these four leks decreased from 162 the first year prior to construction (2008), to 97 in 2010. Similar lek declines were noted in regional leks not associated with wind energy development throughout Carbon County.

We located 95 nests during the study period and their locations were distributed across both study areas. During both study years, the proportion of radiomarked hens that initiated nests (nesting propensity) ranged from $59 \%$ to $77 \%$ within both study areas. Nest success was similar during 2009 and 2010 within both study areas, ranging from $41.9 \%$ to $42.9 \%$ at SRWRA and from $35.3 \%$ to $31.6 \%$ at SMH. Overall, nest success at SRWRA (42.3\%) was higher than at SMH (33.3\%); however, this difference was not statistically significant. During the 2009 and 2010 monitoring seasons, 19 nests were established within $1.6 \mathrm{~km}$ of wind turbines at SMH; the five nests closest to turbines were located $137 \mathrm{~m}, 231 \mathrm{~m}, 248 \mathrm{~m}, 257 \mathrm{~m}$, and $333 \mathrm{~m}$ from the nearest turbine. Five of the 19 nests within $1.6 \mathrm{~km}$ of turbines were successful, but none of the 
5 nests closest to turbines were successful. The relative probability of nest success based on binary logistic regression was not influenced by major roads or wind turbines.

Early brood-rearing success was relatively high during both study years, ranging from $67 \%$ in 2010 (SRWRA) to 100\% in 2009 and 2010 (SMH). Over the two year period, SMH had lower late brooding-rearing success (50\%) compared to SRWRA (72\%). During both study years, the number of females successfully reproducing was lower at SMH (9\%) than at SRWRA (14\%); however, the difference was not statistically significant.

During the study 53 of 116 radio marked birds died. Although cause of death could not be determined for all mortalities, most appeared to have been killed by mammalian predators. During 2009 three radio-collared hens that did not exhibit any signs of trauma were submitted to the Wyoming State Veterinary Lab in Laramie, Wyoming to be examined for the presence of West Nile virus. Two of the three female sage-grouse tested positive for West Nile virus and all were located within the SRWRA study area. The median survival rate was similar for both study areas; however, survival at SRWRA (67\%) was slightly lower than that at SMH (69\%).

Over the course of the study, 2,659 sage-grouse locations were obtained from radio-equipped females, including 1,596 at SRWRA and 1,063 at SMH. These locations were used to map use of each project area by season (nesting, brood-rearing, summer, fall and winter). The sagegrouse populations within both study areas are relatively non-migratory, as radio-marked sagegrouse used similar areas during all annual life cycles.

Percent shrub cover was an important predictor of nesting habitat within $\mathrm{SMH}$, and shrub height was important within the SRWRA study area. Sage-grouse selecting nesting sites within SMH seem to be uninfluenced by the presence of turbines, as distance to nearest turbines was not included in the top SMH model for nest site selection. Sage-grouse selected for nest sites closer to leks and avoided major roads within SMH compared to SRWRA, where they selected for habitats closer to transmission lines. The transmission line at SRWRA has existed for over 10 years and the quality of the habitat surrounding the transmission line may outweigh any potential indirect impacts of the line on habitat selection.

Sage-grouse within $\mathrm{SMH}$ selected brood-rearing habitats further from transmission lines. Brooding sage-grouse in both study areas avoided habitats with a higher percentage of bare ground and selected for habitats that had a higher percentage of shrub (SMH) and litter cover (SRWRA). Distance to nearest turbines was not included in the SMH top model for broodrearing occurrence.

Probability of female habitat selection in summer increased as distance to nearest lek decreased, percent bare ground decreased, and as distance to nearest major road increased within both study areas. Distance to nearest turbine was included in the top SMH summer occurrence model, but its affect on the relative probability of selection was different from what was hypothesized, as sage-grouse in the SMH study area appeared to be selecting for habitats closer to turbines. However, it was found that distance to lek and percent bare ground were 
coincidentally related to distance from turbine, resulting in an increase in relative probability of selection within habitats that were closer to turbines.

The impacts to sage-grouse populations from wind energy infrastructure are not well understood. However, the data presented from this study provide insight into the early interactions of wind energy infrastructure and sage-grouse. We determined that nest success and brood-rearing success were not statistically different between areas with and without wind energy development in the short-term. We also determined that nest success is not influenced by anthropogenic features such as turbines in the short-term. Additionally, female survival was similar among both study areas, suggesting wind energy infrastructure was not impacting female survival in the short-term; however, further analysis is needed to identify habitats with different levels of risk to better understand the impact of wind development on survival. Nest and brood-rearing habitat selection were not influenced by turbines in the short-term; however, summer habitat selection occurred within habitats closer to wind turbines. Major roads were avoided in both study areas and during most of the seasons. The impact of transmission lines varied among study areas, suggesting other landscape features may be influencing selection. Lastly, we monitored occupied leks within both study areas to investigate the response of the breeding population to wind energy infrastructure. Mean lek size decreased from 2008 (predevelopment) to 2010 within the altered habitat (SMH) and unaltered (SRWRA) habitat, although regional declines of sage-grouse leks were also noted during this same time period.

The data provided in this report should be considered preliminary and are not meant to provide a basis for forming any conclusions regarding potential impacts of wind energy development on greater sage-grouse. Although the data collected during the initial phases of this study indicate that greater sage-grouse may continue to use habitats near wind-energy facilities, research conducted on greater sage-grouse response to oil and gas development has found population declines due to oil and gas development may not occur until 2-10 years after development. Therefore, long-term data from several geographic areas within the range of the sage-grouse will likely be required to adequately assess impacts of wind-energy development on greater sage-grouse.

The data collected during this study were sufficient to provide information on lek locations as well as areas of relatively high use by sage-grouse during the breeding, nesting, brood-rearing, summer, fall and winter seasons at the SRWRA. Should wind energy development occur within the SRWRA at some future date, these data should be taken into consideration when designing layout of the facility to avoid or minimize impacts to greater sage-grouse. 


\section{TABLE OF CONTENTS}

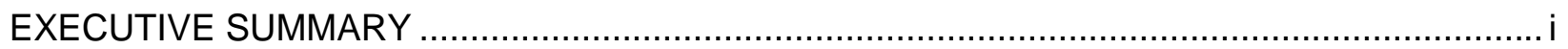

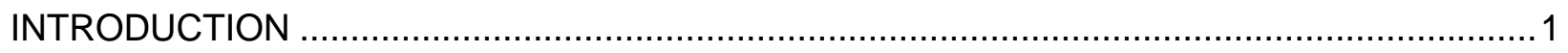

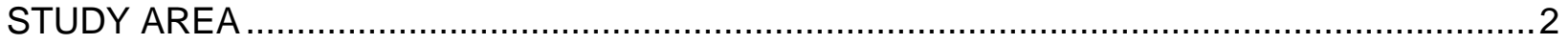

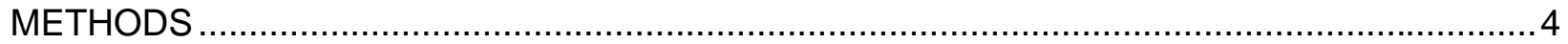

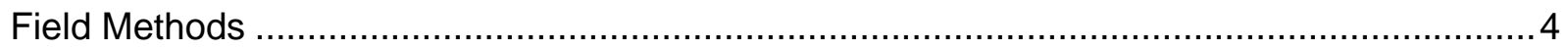

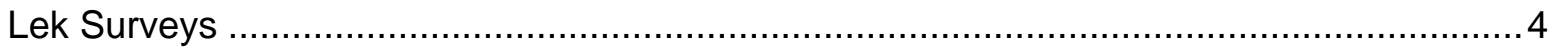

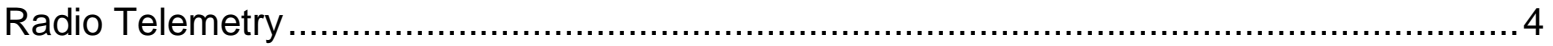

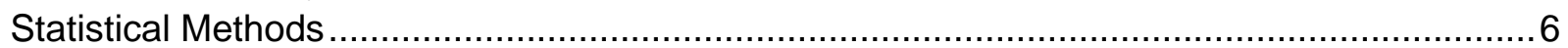

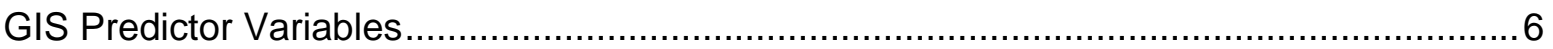

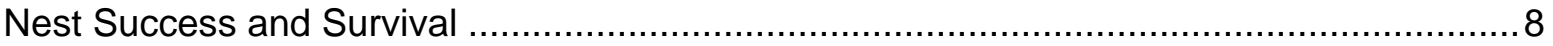

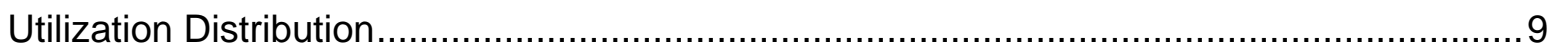

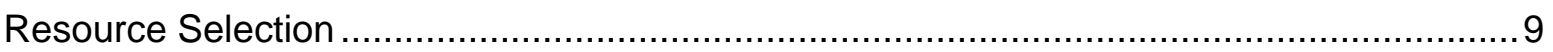

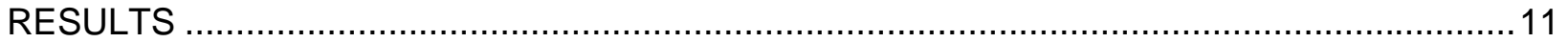

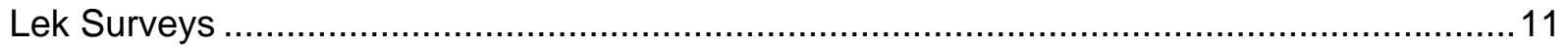

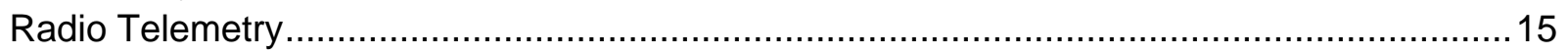

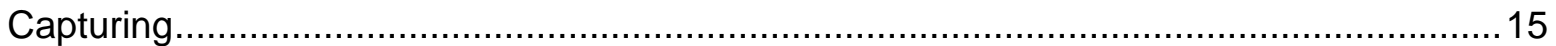

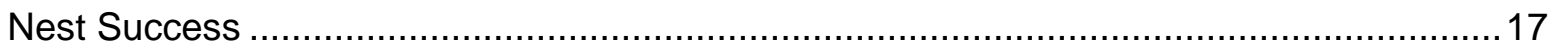

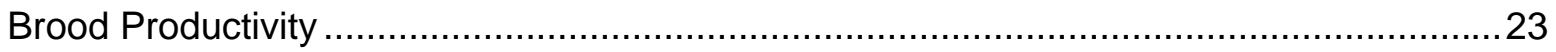

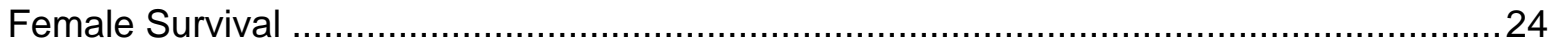

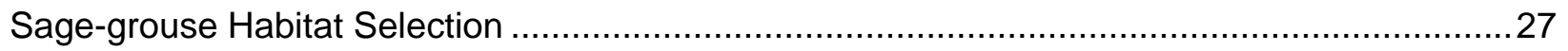

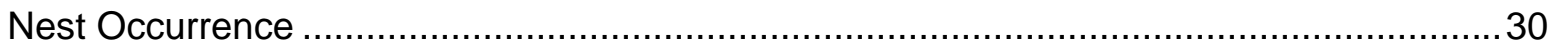

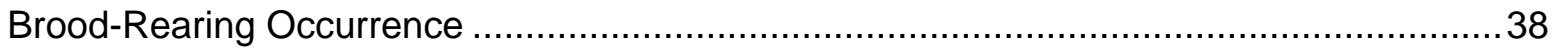

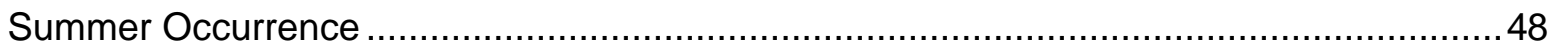

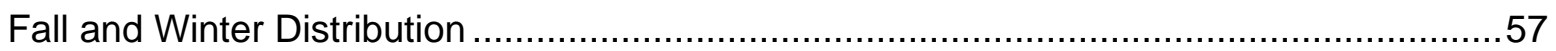

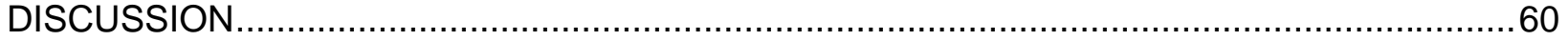

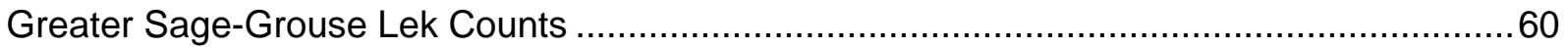

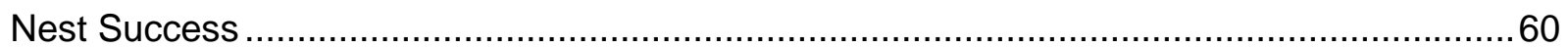

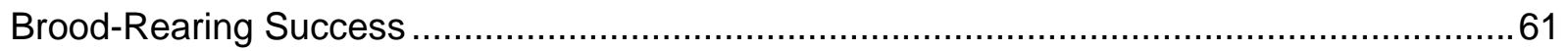

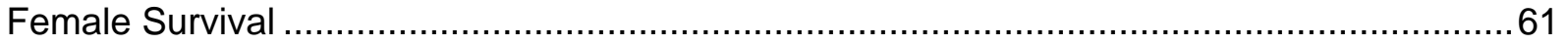

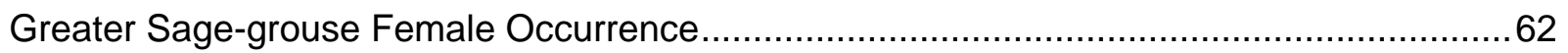

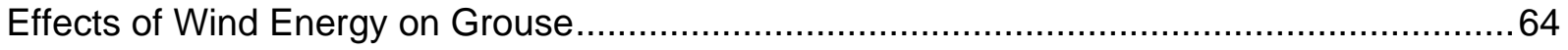

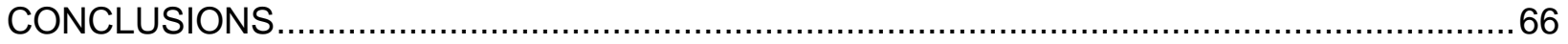

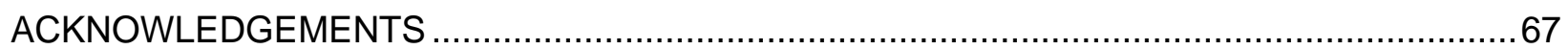

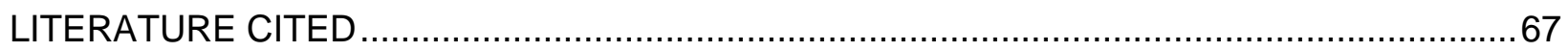




\section{LIST OF TABLES}

Table 1. Explanatory anthropogenic and environmental variables used in model selection for sage-grouse nest site, brood-rearing, and summer habitat selection at the Seven Mile Hill and Simpson Ridge study areas, Carbon County Wyoming, 2009 and 2010......8

Table 2. Maximum counts of male sage-grouse on occupied leks located within the SMH and SRWRA study areas, Carbon County, Wyoming 2008-2010.

Table 3. Historic and current (2010) lek count data (maximum male count) for occupied greater sage-grouse leks within the Simpson Ridge and Seven Mile Hill study areas in Carbon County, Wyoming 1998-2010.

Table 4. Results of female sage-grouse capture efforts within the Simpson Ridge and Seven Mile Hill study areas, Carbon County, Wyoming, 2009-2010......

Table 5. Nesting propensity and nest success of female sage-grouse within the Simpson Ridge and Seven Mile Hill study areas, Carbon County, Wyoming.

Table 6. Fate of 19 sage-grouse nests located within $1.6 \mathrm{~km}$ of the Seven Mile Hill Wind Turbines during the 2009-2010 monitoring seasons.

Table 7. Minimum, maximum, and median distances to each wind energy infrastructure for all successful and failed nests located within the SRWRA and SMH study area $(\mathrm{km}) \ldots 22$

Table 8. Model fit statistics for greater sage-grouse nest success at the Seven Mile Hill and Simpson Ridge study areas, Carbon County, Wyoming, 2009 and 2010. Models are listed according to the model best fitting the data and ranked by ( $\triangle \mathrm{AICc}$ ), the difference between the model with the lowest Akaike's Information Criterion for small samples (AICc) and the AICc for the current model. The top six approximating models are shown. The number of estimated parameters (K), and Akaike's weights (wi) for each model are also presented.

Table 9. Brood-rearing parameters of females with successful nests located within the SRWRA and SMH study areas, Carbon County, Wyoming.

Table 10. Estimated home range size $\left(\mathrm{km}^{2}\right)$ and estimated proportion within each project area for observed nest locations within both study areas in Carbon County, Wyoming.

Table 11. Model fit statistics for greater sage-grouse nest occurrence at the Seven Mile Hill and Simpson Ridge study areas, Carbon County, Wyoming, 2009 and 2010. Models are listed according to the model best fitting the data and ranked by $(\triangle \mathrm{AICc})$, the difference between the model with the lowest Akaike's Information Criterion for small samples (AICC) and the AICc for the current model. The value of the maximized log-likelihood function $(\log [L])$, the number of estimated parameters (K), and Akaike's weights (wi) for each model are also presented. 
Table 12. Selection ratios and slope coefficients for covariates in the sage-grouse top nest site occurrence model for the Seven Mile Hill and Simpson Ridge study areas in Carbon County, Wyoming, USA, 2009 and 2010. Selection ratios measure the multiplicative change in relative probability of selection when a covariate changes by 1 unit, assuming all other covariates remain constant. Selection ratios were not calculated for covariates involved with a quadratic effect because they were dependent on values of other variables.

Table 13. The proportion of nest occurrence predictive bin values within $1.6 \mathrm{~km}$ of Seven Mile Hill turbines and within the Simpson Ridge project area.

Table 14. Estimated home range size $\left(\mathrm{km}^{2}\right)$ and estimated proportion within each project area for observed brood-rearing locations within both study areas in Carbon County, Wyoming.

Table 15. Model fit statistics for greater sage-grouse nest occurrence at the Seven Mile Hill and Simpson Ridge study areas, Carbon County, Wyoming, 2009 and 2010. Models are listed according to the model best fitting the data and ranked by $(\triangle \mathrm{AICC})$, the difference between the model with the lowest Akaike's Information Criterion for small samples (AICc) and the AICc for the current model. The value of the maximized log-likelihood function $(\log [\mathrm{L}])$, the number of estimated parameters $(\mathrm{K})$, and Akaike's weights (wi) for each model are also presented.

Table 16. Selection ratios and slope coefficients for covariates in the sage-grouse top brood-rearing occurrence model for the Seven Mile Hill and Simpson Ridge study areas in Carbon County, Wyoming, USA, 2009 and 2010. Selection ratios measure the multiplicative change in relative probability of selection when a covariate changes by 1 unit, assuming all other covariates remain constant. Selection ratios were not calculated for covariates involved with a quadratic effect because they were dependent on values of other variables.

Table 17. The proportion of brood-rearing predictive bin values within 1-mile of Seven Mile Hill turbines and within the Simpson Ridge Wind.

Table 18. Estimated home range size $\left(\mathrm{km}^{2}\right)$ and estimated proportion within each project area for observed summer locations within both study areas in Carbon County, Wyoming.

Table 19. Model fit statistics for greater sage-grouse summer occurrence at the Seven Mile Hill and Simpson Ridge study areas, Carbon County, Wyoming, 2009 and 2010. Models are listed according to the model best fitting the data and ranked by $(\triangle \mathrm{AICc})$, the difference between the model with the lowest Akaike's Information Criterion for small samples (AICc) and the AICc for the current model. The value of the maximized log-likelihood function $(\log [L])$, the number of estimated parameters (K), and Akaike's weights (wi) for each model are also presented. 
Table 20. Selection ratios and slope coefficients for covariates in the sage-grouse top summer occurrence model for the Seven Mile Hill and Simpson Ridge study areas in Carbon County, Wyoming, USA, 2009 and 2010. Selection ratios measure the multiplicative change in relative probability of selection when a covariate changes by 1 unit, assuming all other covariates remain constant. Selection ratios were not calculated for covariates involved with a quadratic effect because they were dependent on values of other variables.

Table 21. The proportion of summer occurrence predictive bin values within $1.6 \mathrm{~km}$ of Seven Mile Hill turbines and within the Simpson Ridge

Table 22. Estimated home range size $\left(\mathrm{km}^{2}\right)$ and estimated proportion within each project area for observed fall and winter locations within both study areas in Carbon County, Wyoming, 2009-2010.

\section{LIST OF FIGURES}

Figure 1. Location of the proposed Horizon Wind Energy Simpson Ridge project, the existing PacifiCorp Seven Mile Hill wind energy facility, the proposed Iberdrola Renewables Pine Draw project, and greater sage-grouse core population areas in Carbon County, Wyoming.

Figure 2. Simpson Ridge study area and 6.4-km buffer, as well as infrastructure (wind turbines, major roads, access roads, and transmission lines) at the Seven Mile Hill and Simpson Ridge study areas located in Carbon County, Wyoming.

Figure 3. Occupied lek locations monitored from 2008 to 2010 at the Simpson Ridge Wind Resource Area, Carbon County, Wyoming.

Figure 4. Female sage-grouse capture locations during the 2009 and 2010 study years at the Seven Mile Hill and Simpson Ridge study areas in Carbon County, Wyoming.........16

Figure 5. Nest fate and locations of observed sage-grouse nests within the Seven Mile Hill and Simpson Ridge Study areas, Carbon County, Wyoming, 2009 and 2010.

Figure 6. Apparent nest success of monitored sage-grouse during the 2009 and 2010 monitoring seasons for each study area in Carbon County, Wyoming.

Figure 7. Nest fate and locations of observed sage-grouse nests within $1.6 \mathrm{~km}$ of turbines located at Seven Mile Hill Wind Energy Facility, Carbon County, Wyoming.

Figure 8. Mean distance of sage-grouse nests located within the Seven Mile Hill and Simpson Ridge study areas during the 2009-2010 study period, Carbon County, Wyoming.

Figure 9. Observed female sage-grouse mortality locations within the Seven Mile Hill and Simpson Ridge study areas in Carbon County, Wyoming, 2009-2010. 
Figure 10. Kaplan-Meier survival estimation for monitored female sage-grouse within both study areas, Seven mile Hill (a) and Simpson Ridge (b) from April 2008 through March 2011.

Figure 11. All sage-grouse locations observed within the Seven Mile Hill and Simpson Ridge study areas, Carbon County, Wyoming, 2009-2010.

Figure 12. Utilization distributions of sage-grouse nest locations within the Seven Mile Hill and Simpson Ridge study areas in Carbon County, Wyoming, 2009-2010.

Figure 13. Relative probability of sage-grouse nest site occurrence and $90 \% \mathrm{Cl}$ within the Seven Mile Hill study area as a function of top model covariates, Carbon County, Wyoming, 2009 and 2010. Variables that are not plotted were held constant at their median value.

Figure 14. Relative probability of sage-grouse nest site occurrence and $90 \% \mathrm{Cl}$ within the Simpson Ridge study area as a function of top model covariates, Carbon County, Wyoming, 2009 and 2010. Variables that are not plotted were held constant at their median value.

Figure 15. Predicted nesting habitat used by sage-grouse within the Seven Mile Hill study area, Carbon County, Wyoming, 2009 and 2010.

Figure 16. Predicted nesting habitat used by sage-grouse within the Simpson Ridge study area, Carbon County, Wyoming, 2009 and 2010.

Figure 17. Utilization distributions of sage-grouse brood-rearing locations within the Seven Mile Hill and Simpson Ridge study areas, Carbon County, Wyoming, 2009-2010.

Figure 18. Relative probability of sage-grouse brood-rearing occurrence and $90 \% \mathrm{Cl}$ within the Seven Mile Hill study area as a function of top model covariates, Carbon County, Wyoming, 2009 and 2010. Variables that are not plotted were held constant at their median value.

Figure 19. Relative probability of sage-grouse brood-rearing occurrence and $90 \% \mathrm{Cl}$ within the Simpson Ridge study area as a function of top model covariates, Carbon County, Wyoming, 2009 and 2010. Variables that are not plotted were held constant at their median value.

Figure 20. Predicted brood-rearing habitat used by sage-grouse within the Seven Mile Hill study area, Carbon County, Wyoming, 2009 and 2010.

Figure 21. Predicted brood-rearing habitat used by sage-grouse within the Simpson Ridge study area, Carbon County, Wyoming, 2009 and 2010.

Figure 22. Utilization distributions of sage-grouse summer locations at the Simpson Ridge and Seven Mile Hill study areas, Carbon County, Wyoming, 2009-2010.

Figure 23. Relative probability of female sage-grouse summer occurrence and $90 \% \mathrm{Cl}$ within the Seven Mile Hill study area as a function of top model covariates, Carbon County, Wyoming, 2009 and 2010. Variables that are not plotted were held constant at their median value. 
Figure 24. Relative probability of female sage-grouse occurrence and $90 \% \mathrm{Cl}$ within the Simpson Ridge study area as a function of top model covariates, Carbon County, Wyoming, 2009 and 2010. Variables that are not plotted were held constant at their median value.

Figure 25. Predicted summer habitat used by female sage-grouse within the Seven Mile Hill study area, Carbon County, Wyoming, 2009 and 2010.

Figure 26. Predicted summer habitat used by female sage-grouse within the Simpson Ridge study area, Carbon County, Wyoming, 2009 and 2010.

Figure 27. Utilization distributions of sage-grouse fall locations at the Simpson Ridge and Seven Mile Hill study areas, Carbon County, Wyoming, 2009-2010

Figure 28. Utilization distributions of sage-grouse winter locations at the Simpson Ridge and Seven Mile Hill study areas, Carbon County, Wyoming, 2009-2010. 


\section{INTRODUCTION}

EDP Renewables (formerly Horizon Wind Energy) has proposed a wind-energy facility in Carbon County, Wyoming. The Simpson Ridge Wind Resource Area (SRWRA) provides habitat for greater sage-grouse (Centrocercus urophasianus), a federal candidate species considered warranted but precluded for listing under the Endangered Species Act (ESA). Greater sagegrouse in Wyoming are managed by the Wyoming Game and Fish Department (WGFD), and most of their habitat is located on federal or private lands. The conservation of the greater sagegrouse in Wyoming is currently coordinated by the WGFD in cooperation with regional greater sage-grouse working groups in an attempt to increase grouse populations.

The objectives of this study included the following:

1) Evaluate and determine the functionality and viability of greater sage-grouse habitat within the influence of the wind energy development project; and

2) Determine the population impacts of the wind energy project on greater sage-grouse within the influence of the project.

This study was conducted in an area with two proposed wind energy facilities and one existing wind-energy facility. Our general approach was to compare greater sage-grouse habitat selection and demographics on proposed wind energy development areas pre versus postconstruction of the wind energy facilities to determine if wind-energy facilities influence grouse distributions or population growth. The first two years of study were designed to collect data on greater sage-grouse populations in and near the SRWRA necessary to determine pre-treatment seasonally selected habitats (e.g., nesting areas, brood-rearing areas, lek visitation, summer habitat, and winter habitat) and population-level vital rates (e.g., productivity and survival).

This study was selected for continued funding by the National Wind Coordinating Collaborative Sage-Grouse Collaborative (NWCC-SGC) and has been ongoing since March 30, 2011; however, the focus of the study switched from collecting pre-construction data for the SRWRA to collecting post-construction data for the existing 79-turbine PacifiCorp Seven Mile Hill wind energy facility. Future reports summarizing results of this research will be distributed through the NWCC-SGC.

In an effort to prevent listing of greater sage-grouse, the Wyoming Governor's office completed a map of greater sage-grouse core breeding areas prior to when this study was initiated. The core breeding areas include areas with the highest densities of breeding greater sage-grouse in the state, as well as identified areas important for connectivity between populations. The core breeding areas include roughly $25 \%$ of the state but contain $83.1 \%$ of the greater sage-grouse population. As part of that process, in August 2010 Governor Freudenthal issued Executive Order (EO) 2010-4, which was updated on June 2, 2011 by Governor Mead's EO 2011-5. Both of these EO's stated that new development or land uses within Core Population Areas should 
be authorized or conducted only when it can be demonstrated that the activity will not cause declines in greater sage-grouse populations. With regard to wind energy development, EO 2011-5 specifically states that "wind development is not recommended in sage-grouse core areas, but will be reevaluated on a continuous basis as new science, information and data emerge." The SRWRA is in a sage-grouse core population area. As a result of the EOs, EDP Renewables is no longer actively pursuing development of a wind energy facility at Simpson Ridge. Although plans for wind energy development at the SRWRA were put on hold during the time period of this study, the presence of an existing wind energy facility in the project area allowed us to obtain some information on initial sage-grouse response to wind turbines the first two years following construction. To our knowledge these are the first quantitative data on sagegrouse response to an existing wind energy development. The purpose of this report is to present results of the first two full years of data collected from April 1, 2009 through March 30, 2011.

\section{STUDY AREA}

The SRWRA encompasses 28,600.92 acres (44.69 square miles [mi ${ }^{2}$ ) in Carbon County, Wyoming, between the towns of Hanna and Medicine Bow, and south of US Highway 30. Land ownership in the SRWRA includes private fee and leased State of Wyoming lands. The SRWRA contains numerous ridges interspersed with rolling to hilly plains. Elevations range from $6,700-$ 7,840 feet (ft; 2,040-2,390 meters [m]) above sea level. The SRWRA is situated near the base of the Snowy Range Mountains to the south, and lies south of the Shirley Basin. Climate is classified as a semiarid, cold desert with mean annual precipitation of 12 inches (30.5 centimeters $[\mathrm{cm}])$.

Based on land cover classifications (USGS NLCD 2001), the SRWRA is almost entirely (96.7\%) comprised of scrub-shrub, with the dominant shrub being Wyoming big sagebrush (Artemisia tridentata wyomingensis). Grassland composes an additional 1.9\% of the study area. All other habitat types each compose less than 1\% of the area individually, and include 3.6 acres of open water, 209.2 acres of wetland, 155.1 acres of developed areas, 1.9 acres of barren lands, 21.0 acres of forest, and 5.8 acres of pasture/hay.

Two other WRAs are located in close proximity to the SRWRA (Figure 1). The PacifiCorp Seven Mile Hill (SMH) project is located immediately adjacent to and north of the SRWRA. The SMH project was completed at the end of December 2008 and has 79 GE 1.5-MW wind turbines. Just east of the SMH site, and northeast of the SRWRA, is the proposed Iberdrola Renewables Pine Draw WRA (PDWRA). Due to high densities of breeding greater sage-grouse, most of the study area was within the area originally mapped by the State of Wyoming as a greater sage-grouse "Core Population Area." However, in the last update to the core population area map (version 3), both the SMH and PDWRA were excluded from the core area to minimize conflicts with existing and planned wind energy development; the SRWRA has remained in the sage-grouse core area (Figure 1). 


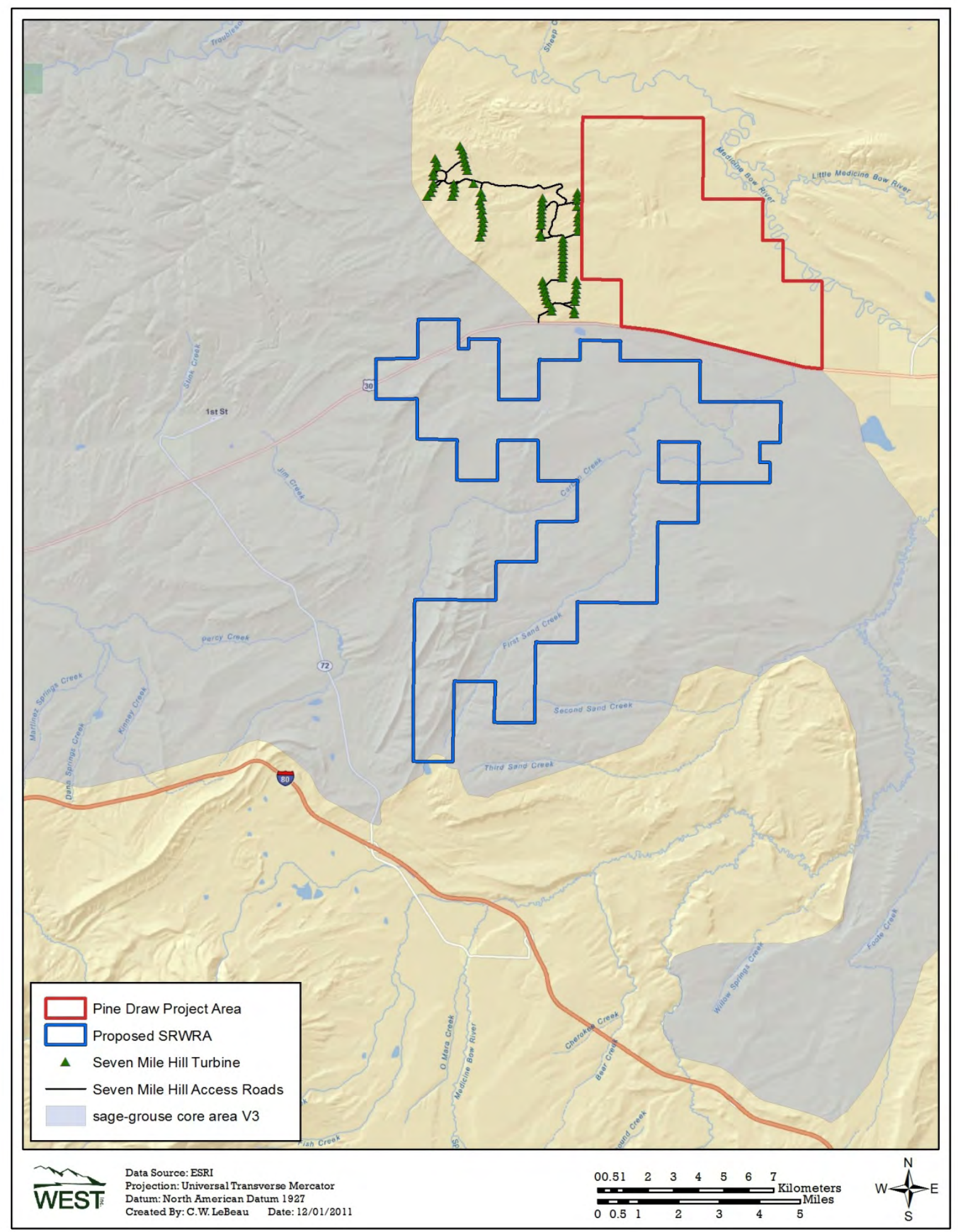

Figure 1. Location of the proposed Horizon Wind Energy Simpson Ridge project, the existing PacifiCorp Seven Mile Hill wind energy facility, the proposed Iberdrola Renewables Pine Draw project, and greater sage-grouse core population areas in Carbon County, Wyoming. 


\section{METHODS}

\section{Field Methods}

\section{Lek Surveys}

To investigate population trends through time, we determined the distribution and numbers of males using active leks throughout the area. Lek search and survey methodology followed that outlined by the WGFD (Christiansen 2007). The locations of known historic and existing greater sage-grouse leks in the SRWRA and $6.4 \mathrm{~km}$ buffer were obtained from the WGFD. To search for undocumented or new leks in the study area, aerial surveys were conducted three times during the first study year (2009). Because it required three survey days to cover the entire SRWRA and the $6.4 \mathrm{~km}$ buffer, nine aerial flights were made during the period April 10-May 6, 2009. Aerial surveys were conducted from fixed-wing aircraft flying parallel transects designed to provide full coverage of the SRWRA and the area encompassed by the $6.4 \mathrm{~km}$ buffer around the SRWRA. All mapped historic and existing leks were flown to check for occupancy. Surveys were conducted from one-half hour before sunrise to two hours after sunrise. Aerial flight transects were oriented north-south and were separated by approximately $1.0 \mathrm{~km}$. Transects were flown at a height of 91 to $137 \mathrm{~m}$ above ground level at an approximate speed of $161 \mathrm{~km}$ per hour. Global Positioning System (GPS) coordinates and the approximate numbers of grouse observed were recorded for all leks located. The majority of nesting (April through June) and early brood-rearing (mid-May through July) occurs within $6.4 \mathrm{~km}$ of the lek (Connelly et al. 2000a). Therefore, the sphere of potential influence of the proposed wind energy facility should not extend greatly beyond leks located within $6.4 \mathrm{~km}$ of the project area.

Ground surveys were conducted to count greater sage-grouse on all identified leks in both 2009 and 2010; aerial surveys were not repeated in 2010. Each active lek located during the 2009 aerial surveys and historic lek locations in the survey area were visited three times to count the number of grouse using the lek. Ground surveys were spaced a minimum of seven days apart. Counts were conducted for a 15-30 minute period in the early morning when the lek was active. Data collected included the maximum number of birds counted by sex (males, females, unknown), date, time period of observation, and weather information (temperature, wind speed and direction, cloud cover, precipitation).

\section{Radio Telemetry}

Female greater sage-grouse were captured by spotlighting and use of hoop nets (Giesen et al. 1982, Wakkinen et al. 1992) on roosts surrounding leks during the breeding period. Attempts were made to capture grouse at lek sites within $6.4 \mathrm{~km}$ of the proposed SRWRA proportionally to the size of the lek (numbers of males). Captured birds were aged, weighed, and fitted with a necklace-mounted radio transmitter. Necklace transmitters weighing $22 \mathrm{~g}$, manufactured by Advanced Telemetry Systems (ATS), and with a battery life of 666 days, were used. The birds were then released at the point of capture and the location was recorded using a GPS.

We relocated each radio-marked female at least twice each week during the prelaying and nesting period (April through June); once every week for brooding females during the brood- 
rearing period (hatch through 15 August); once every week during the summer (June through September); once every other week during the fall (August 15 through November); and once a month during the winter period (December through March). Birds were tracked primarily from the ground using hand-held receivers. We determined grouse locations by triangulation or homing until visibly observed and classified radio-locations as breeding, nesting, brood-rearing, summer, fall, or winter. We used aerial telemetry from fixed-wing aircraft to locate missing birds and to locate birds during winter months when snow conditions prohibited vehicle access to the study area. To obtain data for winter survival and habitat selection, we conducted monthly flights from December through March.

We determined breeding success for each radio-marked female sage-grouse from long range triangulation at least every third day throughout the nesting season, from late April through 15 June. We assumed females were nesting when movements became localized. Nests were located using a progressively smaller concentric circle approach by walking circles around the radio signal using the signal strength as an indication of proximity. Once we visually confirmed the female in an incubating position, the location of the observer was recorded with a GPS unit and a photograph was taken of the habitat surrounding the incubating hen. All future monitoring of the nest was made from remote locations $(>60 \mathrm{~m})$ using triangulation to minimize potential disturbance. Once a nest location was established, we conducted incubation monitoring on an alternate-day schedule to determine nesting fate. For each nest, data were collected on timing of incubation and nest success. All nest locations were mapped using a hand held GPS.

When incubation monitoring indicated that a hen had terminated the nesting effort, we determined nest fate by examining the shell membrane and eggshells. If the membrane was still firmly attached to the shell, the nest was classified as depredated. A membrane that was detached from the eggshell was classified as a successful hatch (Wallestad and Pyrah 1974). We considered a nest successful if $\geq 1$ egg hatched. We determined clutch size by counting eggshells following a successful hatch or the destruction of the nest. We monitored females with unsuccessful nests again every third day to determine re-nesting. Re-nest monitoring was conducted until females were observed flocked with at least one other female. Females that flocked were classified as barren females and locations were recorded weekly.

We located radio-marked females that successfully hatched chicks twice a week through 15 August 2009 and 2010 to monitor brood success and determine brooding habitat selection. We categorized brood success as early (hatch through 14 days post-hatch; Thompson et al. 2006) or late (35 days post-hatch; Walker 2008). Females were considered successful through the early brood-rearing period if $\geq 1$ chick survived to two weeks post-hatch; chick existence during this period was established either through visual confirmation of a live chick or the brooding female's response to the researcher (e.g., chick protective behavior exhibited). We determined fledging success (late brood success) for those females that were successful in early broodrearing by assessing whether a female was brooding chicks through nighttime spotlight surveys conducted on days 35 and 36 post-hatch (Walker 2008). 
To determine female survival, transmitters were equipped with mortality sensors that doubled the pulse rate of the transmitter after eight hours of no movement. When a mortality signal was encountered, the bird was recovered as quickly as possible to maximize the chances that a cause of death could be determined.

\section{Statistical Methods}

\section{GIS Predictor Variables}

We developed a suite of predictor variables used to predict success of fitness parameters and relative probability of selection within both the SRWRA and SMH study areas. Anthropogenic features including major roads and overhead transmission lines have existed within both study areas for more than 10 years. Major roads included paved highways, which were U.S. Highway 30 that traverses east-west separating SRWRA from SMH, Wyoming State Highway 72 that traverses north-south through the study area, and Interstate 80 that traverses east-west south of the study area (Figure 2). The SMH study area includes wind turbines and access roads whereas the SRWRA does not. Major roads and overhead transmission lines were digitized using aerial satellite imagery and ArcMap 10. Turbine locations were obtained from PacifiCorp, the operators of the Seven Mile Hill Wind Energy Facility. In addition to the linear term for the distance to each anthropogenic feature, we also included the quadratic term because in many instance animals may avoid features up to a certain point but beyond this point the affect is less realized.

Environmental variables included vegetation and topography features within both study areas. Vegetation layers used in the analysis were obtained from the Provisional Remote Sensing Sagebrush Habitat Quantification Products (USGS) for Wyoming 30 meter (Homer et al. 2009). This dataset uses a combination of methods to integrate $2.4 \mathrm{~m}$ QuickBird, $30 \mathrm{~m}$ Landsat TM, and $56 \mathrm{~m}$ AWiFS imagery into the characterization of four primary continuous field components (percent bare-ground, percent herbaceous cover, percent litter, and percent shrub) and four secondary components (three subdivisions of shrub - percent sagebrush (Artemisia spp.), percent big sagebrush (Artemisia tridentata spp.), percent Wyoming sagebrush (Artemisia tridentata wyomingensis) - and shrub height), using regression classification (Homer et al. 2009, Homer et al. 2010). Landscape features included elevation, slope, and terrain ruggedness all of which were calculated from a $10 \mathrm{~m}$ National Elevation Dataset (USGS, EROS Data Center). Terrain ruggedness captures the variability in slope and aspect into a single measure ranging from 0 (no terrain variation) to 1 (complete terrain variation; Sappington et al. 2005; Table 1). In addition, we included distance to nearest occupied lek as a covariate because sage-grouse are known to select habitats in the vicinity of their leks (Aldridge and Boyce 2007). 


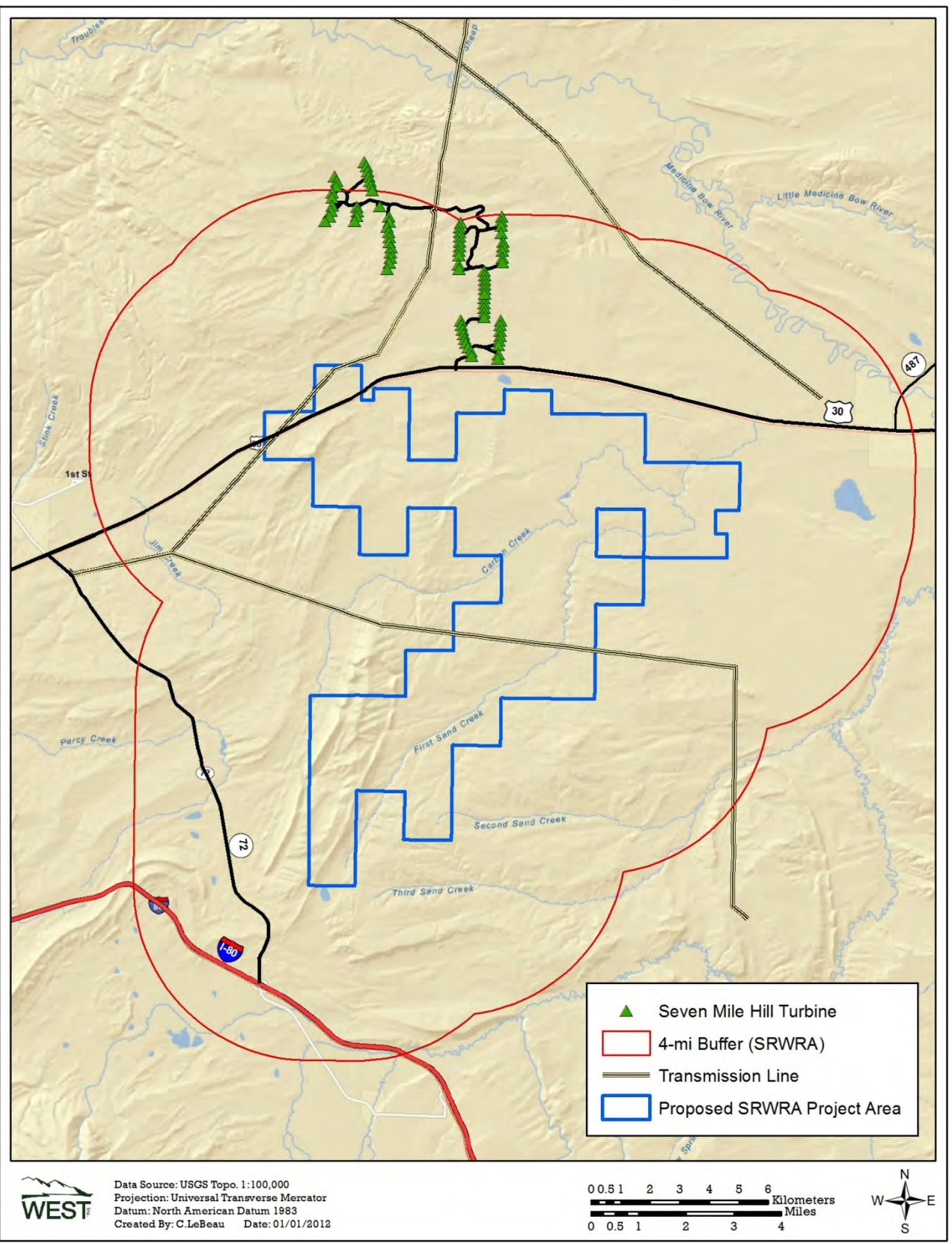

Figure 2. Simpson Ridge study area and 6.4-km buffer, as well as infrastructure (wind turbines, major roads, access roads, and transmission lines) at the Seven Mile Hill and Simpson Ridge study areas located in Carbon County, Wyoming. 
Table 1. Explanatory anthropogenic and environmental variables used in model selection for sage-grouse nest site, brood-rearing, and summer habitat selection at the Seven Mile Hill and Simpson Ridge study areas, Carbon County Wyoming, 2009 and 2010.

\begin{tabular}{ll}
\hline \hline \multicolumn{1}{c}{ Variable } & Variable description \\
\hline dist_major_rds & \\
& Distance to nearest major road [WYO HWY 72, US HWY \\
dist_major_rds ${ }^{2}$ & $287 / 30$, and I-80 $(\mathrm{km})$ ] \\
dist_tline & Distance to nearest major road [WYO HWY 72, US HWY \\
dist_tline ${ }^{2}$ & $287 / 30$, and I-80 $(\mathrm{km})]^{2}$ \\
dist_turbine & Distance to nearest overhead transmission line $(\mathrm{km})$ \\
dist_turbine ${ }^{2}$ & Quadratic term for distance to nearest overhead transmission \\
\hline & line $(\mathrm{km})^{2}$ \\
\hline Bare ground & Distance to nearest turbine (km) \\
Big_sagebrush & Quadratic term for distance to nearest turbine $(\mathrm{km})^{2}$ \\
Elevation & Environmental \\
Herbaceous & Percent bare ground \\
Litter & Percent big sagebrush (Artemisia tridentata spp.) \\
Sagebrush & altitude above sea level (m) \\
Shrub & Percent herbaceous cover \\
Shrub_hgt & Percent litter \\
Slope & Percent sagebrush (Artemisia spp.) \\
Terrain ruggedness & Percent shrub cover \\
Wyoming big sagebrush & Shrub height (0-253 cm) \\
\hline \hline
\end{tabular}

Nest Success and Survival

We used binary logistic regression to predict the probability of nest success relative to four infrastructure features (wind turbine, turbine access road, major road, transmission line, see Figure 2 for locations of infrastructure in the project area). Along with the four anthropogenic variables, we considered uncorrelated multiple habitat variables during model selection (Table 1). We extracted the average values representing each habitat feature within $0.46 \mathrm{~km}$ (median distance between consecutive year's nests) of each nest location. In addition, we included an indicator variable for age of each sage-grouse (i.e., 1=adult and $0=$ juvenile). We used an information-theoretic approach to model the probability of nest success using Akaike's Information Criteria (AIC). The best approximating model was identified by comparing the AICC (AIC adjusted for small sample sizes; Burnham and Anderson 2002) values between the different models to identify the model with the lowest AICc value (Burnham and Anderson 2002). 
We tested 19 different models to predict the relative probability of nest success in relation to infrastructure and environmental variables within both study areas.

Female survival was estimated using the Kaplan-Meier analysis technique where the survival function is the probability of an arbitrary animal in the population surviving units of time from the beginning of the study (Polluck et al. 1998). We calculated monthly survival for all monitored female sage-grouse from April 2009 to March 2011.

\section{Utilization Distribution}

Home ranges were estimated using a kernel density estimator which is the standard for nonmechanistic estimation of utility distributions (UD; Kernohan et al. 2001). The estimated value of the UD at a specific location point (i.e., sage-grouse location) was calculated by

$$
\hat{f}(x)=\frac{1}{n h^{2}} \sum_{i=1}^{n} K\left[\frac{x-X_{i}}{h}\right]
$$

Where $\hat{f}(x)$ is the estimated probability density function, or UD, $n$ is the number of locations, $h$ is the smoothing parameter or bandwidth, $X$ contains the $x$ and $y$ coordinates for the $n$ observed locations, $x$ is the point at which the kernel estimate is calculated, and $K($.$) is the kernel function,$ a bivariate symmetric function (Worton 1989). We used a fixed kernel method (Worton 1989) where the same bandwidth was used over the entire study areas. Least squares cross validation was used to determine the bandwidth to minimize error between the estimated and true density. All UDs were estimated using Animal Movements extension in ArcView 3.2.

\section{Resource Selection}

We developed resource selection functions (RSF) to estimate probability of selection within the SRWRA and SMH. The SMH and SRWRA study areas are separated by U.S. Highway 30/287; however, the minimum distance between SMH and SRWRA occupied leks was approximately $8.5 \mathrm{~km}$. Sage-grouse movements between study areas was relatively low (i.e., $0.05 \%$ of all sage-grouse and $>0.001 \%$ of all locations). Consequently, sage-grouse that were captured on leks north of U.S. Highway 30/287 were included in the SMH analysis area and sage-grouse captured south of U.S. Highway 30/287 were included in the SRWRA analysis area. In addition, the proximity of leks within $\mathrm{SMH}$ to turbines suggests a higher degree of influence of wind energy infrastructure on sage-grouse compared to sage-grouse captured on leks within the SRWRA study area.

We used nest locations and locations obtained during the brood-rearing period (hatch through 35 days post-hatch) and summer period (1 June through 31 August) to model sage-grouse occurrence throughout both study areas. Because there were a limited number of locations (i.e., $\leq 20$ per season) for each sage-grouse, we pooled the data across seasons and years and employed a Type I study design where habitat use and availability were estimated at the population level (Thomas and Taylor 2006). 
Binary logistic regression was used to estimate RSF's within both study areas to identify the relative probability of selection as a function of environmental and infrastructure variables (Boyce et al. 2002, Manly et al. 2002, Carpenter et al. 2010). Logistic regression is widely used and is a valuable tool at estimating RSF and evaluating wildlife habitat relationships (Manly et al 2002, Johnson et al. 2006).

To define available habitat, we created a $100 \%$ minimum convex polygon surrounding all observed locations within each season and study area. Using a geographic information system (GIS), we randomly generated available locations at five times the number of total observed locations. We calculated the distance from each used and available location to nearest major road, overhead transmission line, and turbine. In addition, we extracted the average values representing each environmental feature associated with each used and random available point. These averages were calculated at three different scales representing the mean telemetry error rate $(0.30 \mathrm{~km})$, the median distance between consecutive year's nests $(0.46 \mathrm{~km})$, and the median distance traveled during the brood-rearing and summer season $(1 \mathrm{~km})$. The actual median distance was $1 \mathrm{~km}$ during brood-rearing and $1.6 \mathrm{~km}$ during the summer season; however, for this analysis we used $1.0 \mathrm{~km}$ because this scale has been used in other sagegrouse selection studies (Aldridge and Boyce 2007, Carpenter et al. 2010).

Prior to model development, we tested whether each pair of continuous variables was linearly related using Pearson's correlation coefficients. Many of the variables were correlated with one another ( $r \geq|0.6|$ ). Rather than removing correlated variables we allowed for all variables to compete against each other in a modified forward model selection procedure. The best approximating model was identified by comparing the AICC (AIC adjusted for small sample sizes; Burnham and Anderson 2002) values to identify the model with the lowest AICc value (Burnham and Anderson 2002). AICc penalizes for the number of model parameters, providing an unbiased estimate of the support of a particular candidate model (Burnham and Anderson 2002). Correlated variables were removed during the forward selection process. The forward selection procedure continued until the AICc score among models did not change by more than 2 AICc points or until the model reached 5 variables. Standard errors and confidence intervals for each coefficient and selection ratio were estimated using a bootstrapping technique where we randomly sampled used points with replacement and fitted the final model to the new set of used data (Manly et al. 2002). We used 1,000 bootstrapped iterations to identify the lower and upper confidence limits for each estimate. The value at the $5^{\text {th }}$ percentile of the 1,000 estimates represented the lower limit of a $90 \%$ confidence limit and the value at the $95^{\text {th }}$ percentile represented the upper confidence limit (i.e., the "percentile method"; McDonald et al. 2006). Selection ratios $\left[\left(\exp \left(\beta_{0}\right)-1\right)^{\star} 100\right]$ were calculated from the top model coefficients and were used to interpret the effect of each anthropogenic variable on sage-grouse habitat selection (McDonald et al. 2006). Negative selection ratios indicated a decrease in the relative probability of selection and positive selection ratios indicated an increase.

The top models were validated using a K-fold cross-validation processes (Boyce et al. 2002) to assess how well the top models performed among a set of apportioned data. We randomly allocated the used locations into 5 equal-sized groups. Leaving out one set of used data (k; 
testing); we re-estimated the coefficients in the top models using the available locations and the k-1 groups (training) of used locations. The re-estimated model was then used to make predictions to the available locations and used locations from group $k$. All predictions were binned into 10 classes of equal size using percentiles, and the number of used points in each class was compared to the class rank $(1=$ lowest, $10=$ highest predicted relative probability of selection) using Spearman's rank correlation coefficient. This process was repeated for each of $k=5$ groups of used locations. The Spearman's rank correlation coefficients $(r)$ were averaged to test how well the top model performed on the set of apportioned data.

After estimating the final model for each season and study area, we incorporated the estimated model parameters (i.e., $\beta_{k}$ ) into an RSF to predict occurrence across the study areas.

$$
w(x)=\exp \left(\beta_{0}+\beta_{1} x_{1}+\beta_{2} x_{2}+\cdots+\beta_{k} x_{k}\right)
$$

where $w(x)$ represents the relative probability of selection, the $x$ 's were model covariates and $\beta$ were coefficients to be estimated. We placed a $100 \mathrm{~m} \times 100 \mathrm{~m}$ grid on the landscape within each MCP. Habitat variables associated with each grid cell were extracted based on the representative scale of each habitat variable included in the top logistic regression models. These values represented the various predictor variables measured at each habitat unit or grid cell. Lastly, we calculated RSF values and placed them into 5 quantile bins to represent progressively selected habitats.

\section{RESULTS}

\section{Lek Surveys}

Fourteen greater sage-grouse leks were observed during lek surveys in both study areas (5 within SMH and 9 within SRWRA during 2008, 2009 and 2010 (Table 2; Figure 3). During 2008 (pre-development of $\mathrm{SMH}$ wind energy facility) the maximum number of male birds present at the occupied leks within the SMH study area ranged from 18 males (Hanna Draw East 2) to 74 males (Missouri John), with a mean count of 36 males/lek. During 2009 and 2010, the mean lek counts decreased to 34 and 22 males/leks, respectively. Similarly to SMH, occupied leks located within SRWRA had a mean count of 37 males/lek, ranging from 0 (Old Percy 2) to 111 males (Old Carbon 35-2). The mean male count peaked in 2009 (40 males/lek) then decreased to 23 males/lek in 2010.

Lek count data for all currently occupied leks within both study areas were obtained from the WGFD for the last ten years (Table 3). Because not all leks were counted each year, comparisons based on total number of males on all leks cannot be made. However, changes in mean lek size are a good indicator of population trend. Based on these data, mean lek size increased from 17 males/lek in 1998 to 52 males/lek in 2006. Mean lek size has decreased from 37 to 22 males per lek in the last three years (2008-10; Table 3). 
Prior to construction in 2008, three leks were located within $1.6 \mathrm{~km}$ of the Seven Mile Hill turbines, including the Missouri John, Pine Draw, and Commo 1 leks (Figure 3). A total of 130 males were observed on all of these leks combined in 2008. In 2009, a total of 103 males were counted on these three leks. There were 2 additional leks (Hanna Draw East 1 and 2) located $>3.2$ km; however, these leks were not surveyed in 2009 (Table 2; Figure 3). In 2010, all leks near the Seven Mile Hill turbines were surveyed. Data collected from 2009 through 2010 represent the first and second sage-grouse breeding seasons after the wind-energy facility became operational. The three leks within $1.6 \mathrm{~km}$ were located $0.58,1.6$, and $1.5 \mathrm{~km}$ from the nearest wind turbine (Figure 3). Although the leks remained active, the total number of males counted on these three leks decreased from 130 the first year prior to construction (2008) to 70 in 2010 (Table 2). For all five leks combined, the maximum number of males declined from 180 one year prior to construction to 108 two years after construction.

Table 2. Maximum counts of male sage-grouse on occupied leks located within the SMH and SRWRA study areas, Carbon County, Wyoming 2008-2010.

\begin{tabular}{|c|c|c|c|c|c|}
\hline Lek Name & UTM $x$ & UTM y & Max of 2008 & Max of 2009 & Max of 2010 \\
\hline \multicolumn{6}{|c|}{ Seven Mile Hill } \\
\hline Commo 1 & 388258 & 4642537 & 23 & 21 & 18 \\
\hline Hanna Draw East 1 & 377226 & 4649023 & 32 & NA & 27 \\
\hline Hanna Draw East 2 & 376627 & 4647267 & 18 & NA & 11 \\
\hline Missouri John & 379311 & 4645861 & 74 & 62 & 38 \\
\hline Pine Draw & 387347 & 4645077 & 33 & 20 & 14 \\
\hline Average & & & 36 & 34 & 22 \\
\hline Total & & & 180 & 103 & 108 \\
\hline \multicolumn{6}{|c|}{ Simpson Ridge } \\
\hline Kyle 63 & 387901 & 4625266 & 67 & 68 & 64 \\
\hline Kyle 65 & 382884 & 4622032 & 5 & 8 & 4 \\
\hline Old Carbon 31 & 392053 & 4634123 & 28 & 41 & 28 \\
\hline Old Carbon 32 & 386637 & 4634301 & 9 & 33 & 4 \\
\hline Old Carbon 34 & 381290 & 4633858 & 49 & 49 & 31 \\
\hline Old Carbon 352 & 386841 & 4630480 & 111 & 88 & 41 \\
\hline Old Carbon 37 & 374755 & 4633031 & 54 & 42 & 28 \\
\hline Old Carbon 38 & 382932 & 4635849 & 10 & 1 & 0 \\
\hline Old Percy 2 & 374164 & 4627627 & 0 & 31 & 4 \\
\hline \multicolumn{2}{|l|}{ Average } & & 37 & 40 & 23 \\
\hline \multicolumn{2}{|l|}{ Total } & & 333 & 361 & 204 \\
\hline
\end{tabular}




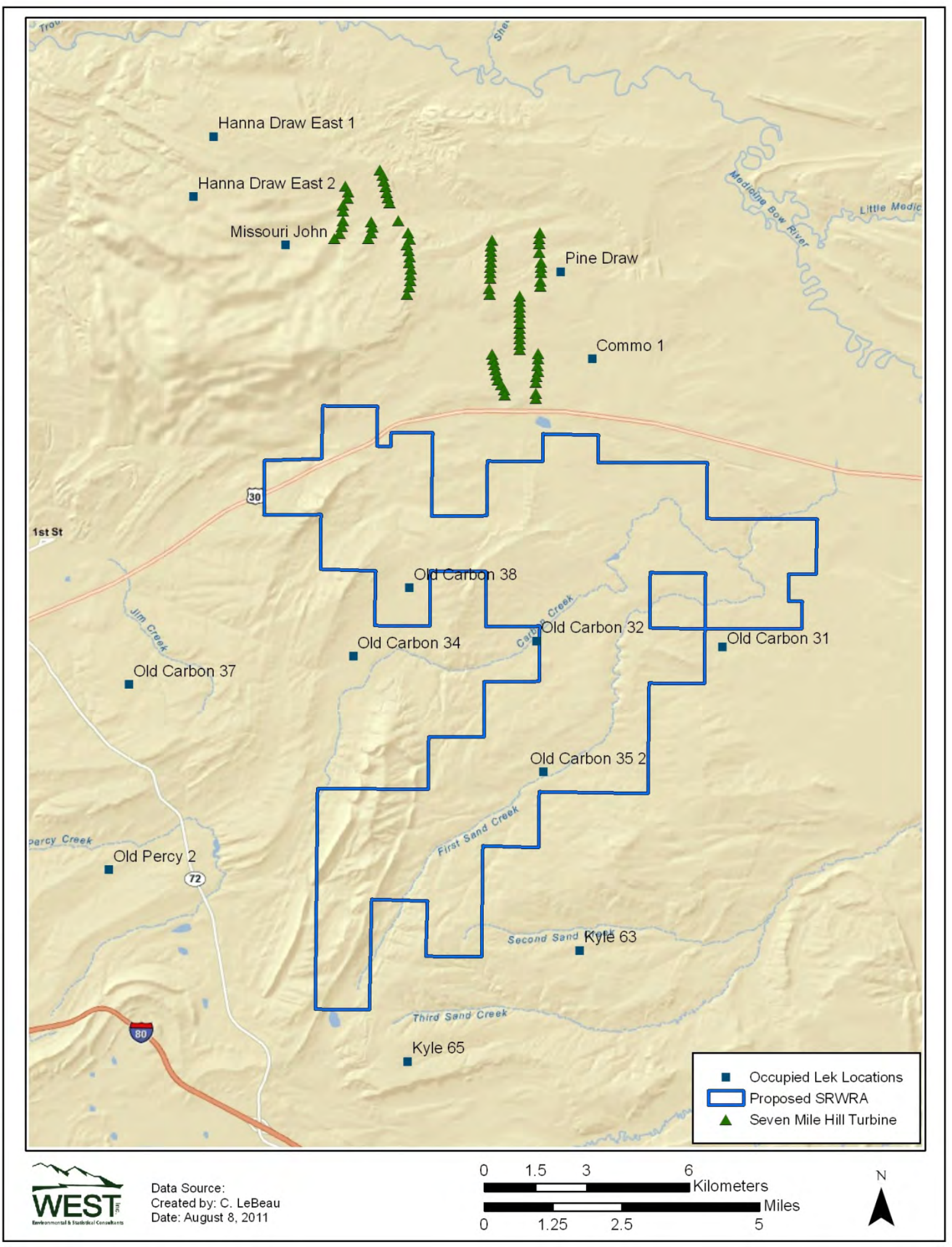

Figure 3. Occupied lek locations monitored from 2008 to 2010 at the Simpson Ridge Wind Resource Area, Carbon County, Wyoming. 
Table 3. Historic and current (2010) lek count data (maximum male count) for occupied greater sage-grouse leks within the Simpson Ridge and Seven Mile Hill study areas in Carbon County, Wyoming 1998-2010.

\begin{tabular}{|c|c|c|c|c|c|c|c|c|c|c|c|c|c|}
\hline Lek Name & 1998 & 1999 & 2000 & 2001 & 2002 & 2003 & 2004 & 2005 & 2006 & 2007 & 2008 & 2009 & 2010 \\
\hline Commo 1 & 13 & 0 & NA & NA & 0 & 48 & NA & NA & 36 & NA & 23 & 21 & 18 \\
\hline Hanna Draw East 1 & NA & NA & NA & NA & NA & NA & NA & NA & NA & NA & 32 & NA & 27 \\
\hline Hanna Draw East 2 & NA & NA & NA & NA & NA & NA & NA & NA & NA & NA & 18 & NA & 11 \\
\hline Kyle 63 & 39 & 45 & 40 & 52 & 48 & 59 & 57 & 81 & 87 & 81 & 67 & 68 & 64 \\
\hline Kyle 65 & 6 & 0 & NA & NA & 1 & NA & 0 & 20 & 16 & 8 & 5 & 8 & 4 \\
\hline Missouri John & 0 & 0 & 65 & 74 & 62 & 81 & NA & NA & 92 & NA & 74 & 62 & 38 \\
\hline Old Carbon 31 & NA & 0 & 0 & NA & NA & 0 & 33 & NA & 49 & 17 & 28 & 41 & 28 \\
\hline Old Carbon 32 & 3 & NA & 0 & NA & 0 & 0 & 0 & NA & 18 & 0 & 9 & 33 & 4 \\
\hline Old Carbon 34 & 13 & 20 & 24 & 23 & 21 & NA & 39 & NA & 44 & 43 & 49 & 49 & 31 \\
\hline Old Carbon 352 & 35 & 52 & 41 & 41 & 36 & 57 & 80 & NA & 118 & 109 & 111 & 88 & 41 \\
\hline Old Carbon 37 & 28 & 38 & 46 & 45 & 58 & 67 & 84 & NA & NA & 57 & 54 & 42 & 28 \\
\hline Old Carbon 38 & 9 & 12 & 14 & 23 & 17 & 30 & 34 & NA & 24 & 3 & 10 & 1 & 0 \\
\hline Old Percy 2 & 23 & 14 & 10 & 12 & 18 & 4 & 0 & 32 & 39 & 2 & 0 & 31 & 4 \\
\hline Pine Draw & NA & NA & NA & NA & NA & NA & NA & NA & NA & NA & 33 & 20 & 14 \\
\hline Mean Lek Size & 17 & 18 & 27 & 39 & 26 & 38 & 36 & 44 & 52 & 36 & 37 & 39 & 22 \\
\hline Total & 169 & 181 & 240 & 270 & 261 & 346 & 327 & 133 & 523 & 320 & 513 & 464 & 312 \\
\hline
\end{tabular}

${ }^{\mathrm{a}} \mathrm{NA}$ - no count apparently conducted 


\section{Radio Telemetry}

\section{Capturing}

We captured 116 female sage-grouse by spotlighting and use of hoop nets on roosts surrounding leks during the 2009 and 2010 breeding seasons (Figure 4). During the 2009 season, we captured 50 female sage-grouse south of U.S. Hwy 30/287 within SRWRA and 25 north of U.S. Hwy 30/287 near SMH from 1-13 April 2009. During the 2010 season we replaced radio-transmitters from birds that died or were censored during the 2009 season to maintain a sample size of 75 female sage-grouse. Forty-one females were captured from 7-13 April 2010 within both study areas (Table 4). During the two years of captures, more juveniles were captured at SRWRA (39\%) than at SMH (22\%). Additionally, the average mass of captured hens ranged from $1.61 \mathrm{~kg}$ to $1.64 \mathrm{~kg}$ (Table 4). 


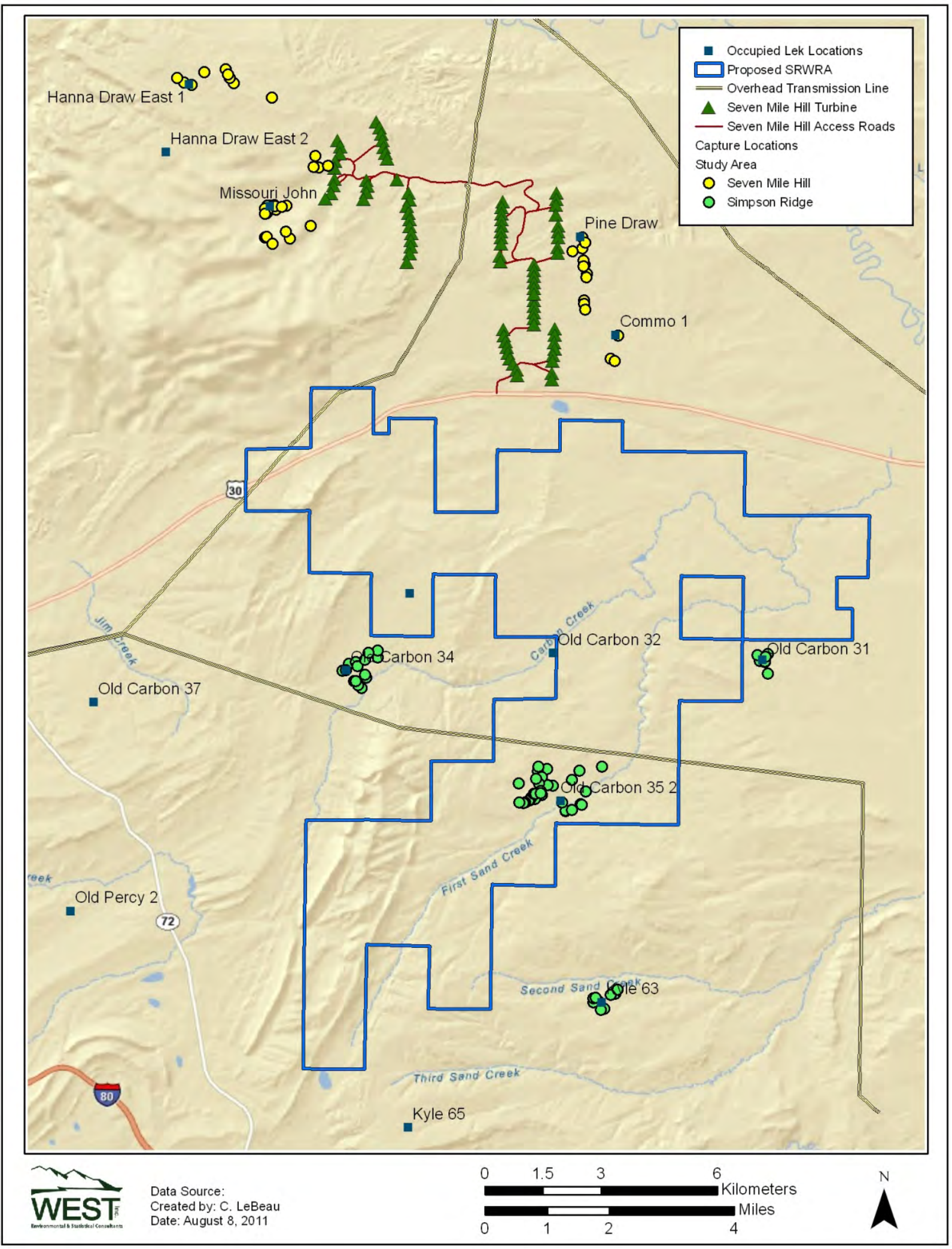

Figure 4. Female sage-grouse capture locations during the 2009 and 2010 study years at the Seven Mile Hill and Simpson Ridge study areas in Carbon County, Wyoming. 
Table 4. Results of female sage-grouse capture efforts within the Simpson Ridge and Seven Mile Hill study areas, Carbon County, Wyoming, 2009-2010.

\begin{tabular}{crrrr}
\hline \hline Study Area & $\begin{array}{c}\text { \# of adult } \\
\text { captured females }\end{array}$ & $\begin{array}{c}\text { \# of juvenile } \\
\text { females captured }\end{array}$ & $\begin{array}{c}\text { \# total of females } \\
\text { captured }\end{array}$ & $\begin{array}{c}\text { Average mass } \\
\text { (kg)* }\end{array}$ \\
\hline Simpson Ridge & $32(64 \%)$ & $18(36 \%)$ & 50 & 1.61 \\
Seven Mile Hill & $20(80 \%)$ & $5(20 \%)$ & 25 & 1.59 \\
\hline 2010 & & & & \\
\hline Simpson Ridge & $8(50 \%)$ & $8(50 \%)$ & 16 & 1.64 \\
Seven Mile Hill & $19(76 \%)$ & $6(24 \%)$ & 25 & 1.55 \\
\hline 2009 \& 2010 & & & & \\
\hline Simpson Ridge & $40(61 \%)$ & $26(39 \%)$ & 66 & 1.63 \\
Seven Mile Hill & $39(78 \%)$ & $11(22 \%)$ & 50 & 1.57 \\
Total & $79(68 \%)$ & $37(32 \%)$ & 116 & 1.60 \\
\hline \hline
\end{tabular}

${ }^{\star}$ Average mass for adult female sage-grouse only

\section{Nest Success}

We located 95 nests during the study period and their locations were distributed across both study areas (53 within the SRWRA area and 42 within the SMH area; Figure 5). Nesting propensity was defined as the number of monitored hens observed initiating a nesting attempt. During both study years, nesting propensity ranged from $59 \%$ to $77 \%$ within both study areas (Table 5). SRWRA had more nests during both study years compared to SMH; however, SMH had six re-nest attempts compared to one re-nest attempt at SRWRA. Nest hatch dates ranged from 26 May to 28 June (mean = 1 June) for all assumed first nesting attempts and from 29 June to 2 July (mean $=30$ June) for all assumed second nesting attempts.

Nest success was defined as the number of nests successfully hatching $\geq 1$ egg. Re-nests are a result of a failed nesting attempt and including re-nests can overestimate nest success; therefore, re-nests were excluded from the apparent nest success. Two of the six observed renests within SMH were successful and the one re-nest observed within SRWRA was unsuccessful. Nest success was calculated for all first nesting attempts. Nest success was similar during 2009 and 2010 within both study areas, ranging from 40\% to 42\% at SRWRA and from $28 \%$ to $35 \%$ at SMH. Overall, nest success at SRWRA $(0.41 \%[0.27,0.55])$ was higher than at $\mathrm{SMH}(0.31 \%[0.15,0.48])$; however, this difference was not statistically significant (Table 5 , Figure 6). Clutch size ranged from 2-9 eggs within both the SRWRA and SMH areas, with a mean of 5.2 eggs during both years. Nest hatch dates ranged from May 23 to July 5. 


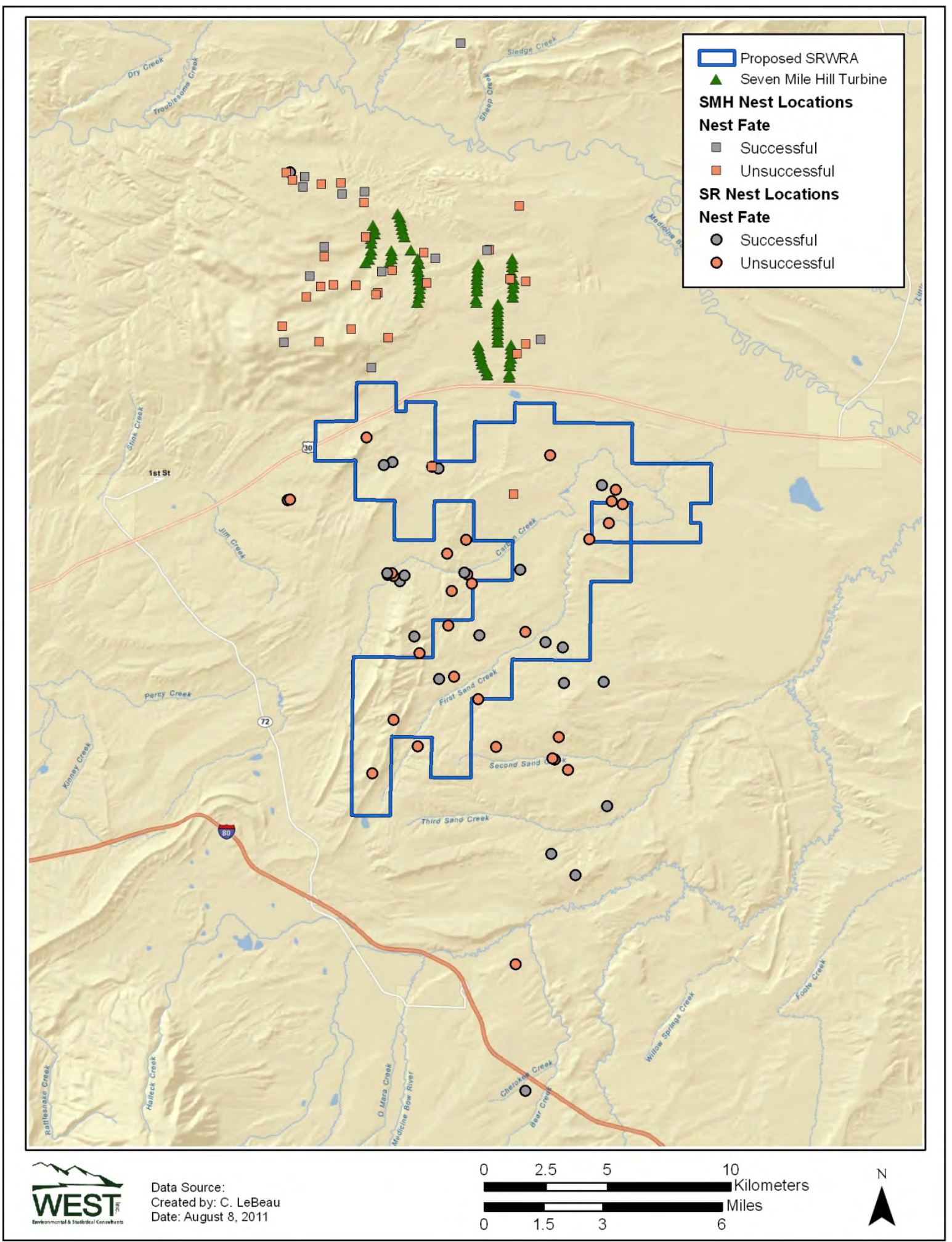

Figure 5. Nest fate and locations of observed sage-grouse nests within the Seven Mile Hill and Simpson Ridge Study areas, Carbon County, Wyoming, 2009 and 2010. 
Table 5. Nesting propensity and nest success of female sage-grouse within the Simpson Ridge and Seven Mile Hill study areas, Carbon County, Wyoming.

\begin{tabular}{|c|c|c|c|c|}
\hline Study Area & $\begin{array}{c}\text { \# of } \\
\text { monitored } \\
\text { females }\end{array}$ & $\begin{array}{c}\text { Nesting propensity (\# of } \\
\text { nests/monitored } \\
\text { females }\end{array}$ & $\begin{array}{c}\# \text { of } \\
\text { Observed } \\
\text { Nests* }\end{array}$ & $\begin{array}{c}\text { Nest Success } \\
\text { (successful nests/total } \\
\text { number of nests \%)* }\end{array}$ \\
\hline & \multicolumn{4}{|c|}{2009} \\
\hline Simpson Ridge & 50 & $0.67(4)$ & 31 & 41.9 \\
\hline \multirow[t]{2}{*}{ Seven Mile Hill } & 25 & $0.77(3)$ & 17 & 35.3 \\
\hline & \multicolumn{4}{|c|}{2010} \\
\hline Simpson Ridge & 43 & $0.66(11)$ & 21 & 42.9 \\
\hline \multirow[t]{2}{*}{ Seven Mile Hill } & 39 & $0.59(7)$ & 19 & 31.8 \\
\hline & \multicolumn{4}{|c|}{ Combined 2-Year (2009-2010) Totals } \\
\hline Simpson Ridge & 93 & $0.84(15)$ & 52 & $42.3(95 \% \mathrm{Cl} 28.7,56.8)$ \\
\hline Seven Mile Hill & 64 & $0.67(10)$ & 36 & $33.3(95 \% \mathrm{Cl} 18.6,50.0)$ \\
\hline
\end{tabular}

*Does not include observed re-nests

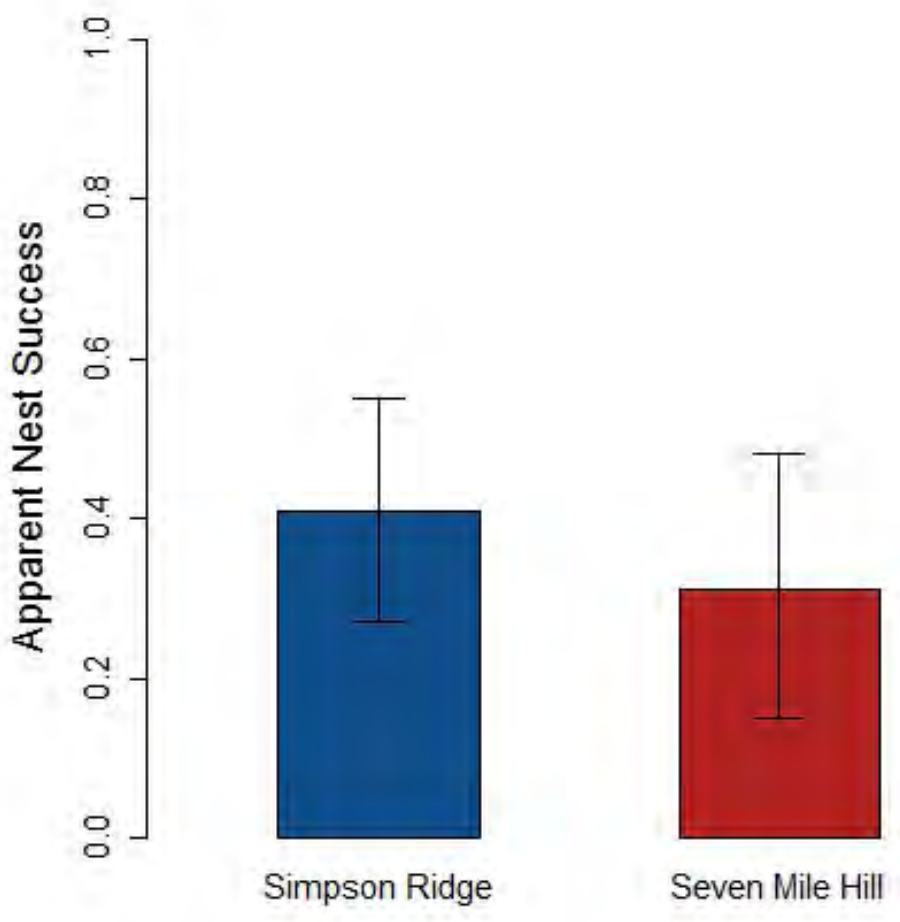

Figure 6. Apparent nest success of monitored sage-grouse during the 2009 and 2010 monitoring seasons for each study area in Carbon County, Wyoming. 
During 2009, the distance from each hen's nest location to their lek of capture ranged from 0.26 $\mathrm{km}$ to $8.81 \mathrm{~km}$, with a median of $3.22 \mathrm{~km}$ in SRWRA. In the SMH vicinity, these distances ranged from $0.81 \mathrm{~km}$ to $4.12 \mathrm{~km}$, with a median distance of $2.35 \mathrm{~km}$. The median distance for both areas combined was $2.83 \mathrm{~km}$. During the 2009 and 2010 monitoring seasons, 19 nests were initiated within $1.6 \mathrm{~km}$ of wind turbines at $\mathrm{SMH}$; the five nests closest to turbines were located $137 \mathrm{~m}, 231 \mathrm{~m}, 248 \mathrm{~m}, 257 \mathrm{~m}$, and $333 \mathrm{~m}$ from the nearest turbine (Table 6; Figure 7). Five of the 19 nests within $1.6 \mathrm{~km}$ of turbines were successful, but none of the 5 nests closest to turbines were successful (Figure 7).

Table 6. Fate of 19 sage-grouse nests located within $1.6 \mathrm{~km}$ of the Seven Mile Hill Wind Turbines during the 2009-2010 monitoring seasons.

\begin{tabular}{lcccc}
\hline \hline & $\begin{array}{l}\text { Distance to } \\
\text { Nearest } \\
\text { Turbine }(\mathbf{m})\end{array}$ & $\begin{array}{l}\text { Distance to } \\
\text { Nearest } \\
\text { Turbine (mi) }\end{array}$ & Year & Nest Fate \\
\hline SRWRA91-10 & 137 & 0.09 & 2010 & Unsuccessful \\
SRWRA111-10 & 231 & 0.14 & 2010 & Unsuccessful \\
SRWRA15-09 & 248 & 0.15 & 2009 & Unsuccessful \\
SRWRA16-09 & 257 & 0.16 & 2009 & Unsuccessful \\
SRWRA25-09 & 333 & 0.21 & 2009 & Unsuccessful \\
SRWRA07-09 & 342 & 0.21 & 2009 & Unsuccessful \\
SRWRA16-09 & 494 & 0.31 & 2010 & Successful \\
SRWRA91-10 & 507 & 0.32 & 2010 & Unsuccessful \\
SRWRA110-10 & 568 & 0.35 & 2010 & Unsuccessful \\
SRWRA94-10 & 641 & 0.40 & 2010 & Successful \\
SRWRA25-09 & 679 & 0.42 & 2010 & Successful \\
SRWRA94-10 & 716 & 0.44 & 2010 & Unsuccessful \\
SRWRA20-09 & 987 & 0.61 & 2009 & Unsuccessful \\
SRWRA82-10 & 1020 & 0.63 & 2010 & Unsuccessful \\
SRWRA108-10 & 1199 & 0.75 & 2010 & Successful \\
SRWRA10-09 & 1332 & 0.83 & 2009 & Unsuccessful \\
SRWRA10-09 & 1401 & 0.87 & 2009 & Unsuccessful \\
SRWRA22-09 & 1409 & 0.88 & 2009 & Successful \\
SRWRA20-09 & 1587 & 0.99 & 2010 & Unsuccessful \\
\hline \hline
\end{tabular}




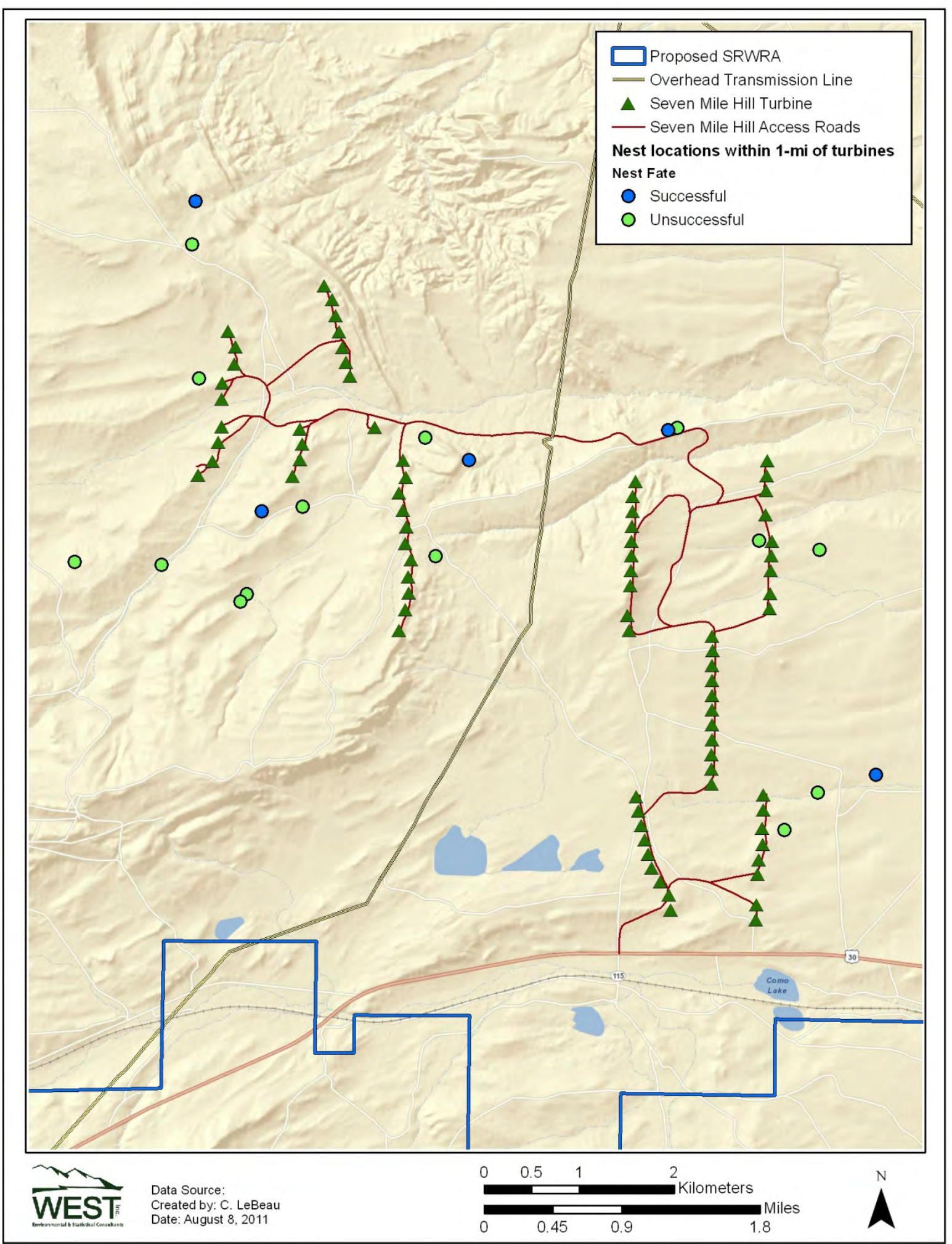

Figure 7. Nest fate and locations of observed sage-grouse nests within $1.6 \mathrm{~km}$ of turbines located at Seven Mile Hill Wind Energy Facility, Carbon County, Wyoming. 
The proximity of these nests to each infrastructure feature varied throughout the study area (Table 7). The overall median distance of successful nests from the anthropogenic infrastructure features was slightly greater than the median distance of failed nests $(4.80 \mathrm{~km}$ and $4.57 \mathrm{~km}$, respectively; Table 7$)$. The mean distance to major roads and $\mathrm{SMH}$ turbines was greater for all successful nests $(6.79 \pm 1.12$ and $8.10 \pm 2.18$, respectively) compared to failed nests (5.63 \pm 0.65 and $6.62 \pm 1.47$, respectively); however, these differences were not statistically significant (Table 7, Figure 8).

Table 7. Minimum, maximum, and median distances to each wind energy infrastructure for all successful and failed nests located within the SRWRA and SMH study area (km).

\begin{tabular}{lcccccccccc}
\hline \hline & \multicolumn{4}{c}{ Successful Nests } & \multicolumn{5}{c}{ Failed Nests } \\
\hline Infrastructure & Min & Max & Med. & Mean & SE & Min & Max & Med. & Mean & SE \\
\hline SMH Turbine & 0.46 & 29.0 & 7.58 & $8.10 \pm 2.18$ & 1.11 & 0.10 & 23.9 & 5.89 & $6.62 \pm 1.47$ & 0.75 \\
Major Roads & 0.51 & 13.9 & 6.80 & $6.79 \pm 1.12$ & 0.57 & 0.62 & 10.2 & 5.56 & $5.63 \pm 0.65$ & 0.33 \\
$\begin{array}{l}\text { Transmission } \\
\text { Line }\end{array}$ & 0.46 & 12.7 & 2.79 & $3.28 \pm 0.86$ & 0.44 & 0.48 & 9.36 & 3.57 & $3.39 \pm 0.53$ & 0.27 \\
All & & & & & & & & & & \\
Anthropogenic & 0.26 & 6.1 & 1.69 & $2.03 \pm 0.49$ & 0.25 & 0.5 & 5.78 & 2.11 & $2.26 \pm 0.45$ & 0.23 \\
\hline \hline
\end{tabular}

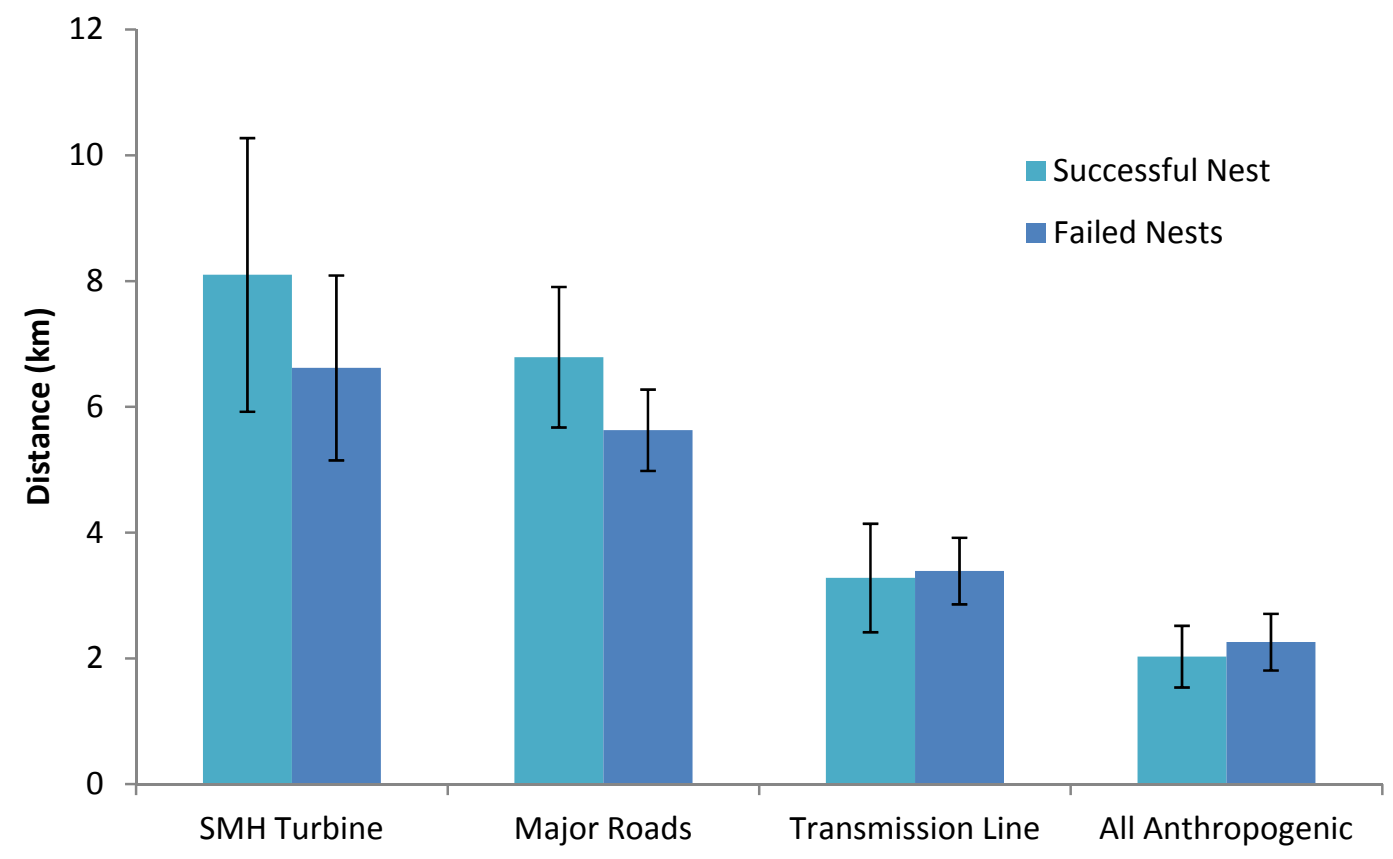

Figure 8. Mean distance of sage-grouse nests located within the Seven Mile Hill and Simpson Ridge study areas during the 2009-2010 study period, Carbon County, Wyoming. 
In addition to estimating the apparent nest success of sage-grouse within both study areas, we estimated the probability of nest success relative to environmental and anthropogenic variables using binary logistic regression. We developed 19 different models to predict the relative probability of nest success. We considered all uncorrelated predictor variables and included interactions among shrub height and herbaceous cover and percent bare ground cover and slope. We included an indicator variable for defining each study area (i.e.,1=SMH and $0=$ SRWRA). Study area was not significant at predicting nest success (slope coefficient $=-0.42$, $90 \%$ confidence interval -1.20 to 0.33 ). Age of female sage-grouse producing nests was included in the top model; however, this model did not differ more than 2 AICc points from the null model (Table 8). The relative probability of nest success was not influenced by major roads or turbines (slope coefficient $=0.11$ and $0.05,90 \%$ confidence interval -0.02 to 0.26 and -0.02 to 0.11 , respectively).

Table 8. Model fit statistics for greater sage-grouse nest success at the Seven Mile Hill and Simpson Ridge study areas, Carbon County, Wyoming, 2009 and 2010. Models are listed according to the model best fitting the data and ranked by $(\triangle A I C c)$, the difference between the model with the lowest Akaike's Information Criterion for small samples (AICc) and the AICc for the current model. The top six approximating models are shown. The number of estimated parameters (K), and Akaike's weights (wi) for each model are also presented.

\begin{tabular}{lccccc}
\hline \hline \multicolumn{1}{c}{ Model } & $\mathrm{k}$ & $\mathrm{AICc}$ & \multicolumn{1}{c}{$\Delta \mathrm{AICc}$} & $w_{i}$ \\
\hline age & 2 & 114.8 & 0.00 & 0.32 \\
null & 1 & 115.6 & 0.76 & 0.22 \\
dist_major_rds & 2 & 115.8 & 0.97 & 0.20 \\
dist_turbine & 2 & 116.2 & 1.37 & 0.16 \\
bare_ground, dist_major_rds, age & 4 & 117.3 & 2.46 & 0.09 \\
shrub, wyoming_sagebrush, turbine, major_rds, age & 6 & 121.4 & 6.58 & 0.01 \\
\hline \hline
\end{tabular}

\section{Brood Productivity}

A total of 19 females were monitored during the brood-rearing period in 2009 (13 within SR and 6 within $\mathrm{SMH}$ ) and 15 females were monitored (9 within SR and 6 within SMH) during 2010. Early brood-rearing success was relatively high during both study years, ranging from $92.3 \%$ in 2009 and $66.7 \%$ in 2010 (SR) to 100\% in 2009 and 2010 (SMH). Of the successful early brood females, 11 broods were successful through the late brood-rearing period in 2009 (9 within SR and 2 within SMH) and 8 were successful in 2010 (4 within SR and 4 within SMH) (Table 9). Late brood-rearing success was similar during both study years $(2009=61.1 \%$; $90 \% \mathrm{Cl}$ : $39.4-$ 79.5\%; $2010=80.0 \%$; 95\% Cl: 49.0-95.6\%). In addition, over the 2-year period, late broodrearing success was $22 \%$ greater in the SR study area than in $\mathrm{SMH}(\mathrm{SMH}=54.5 \%$; $90 \% \mathrm{Cl}$ : 27.8-79.2\%, $n=11$; SR =76.5\%, 90\% Cl: 53.6-91.0\%, $n=17$ ); however, there was no statistical difference in the means (90\% Cl: $-15.5-59.3 \%)$. The total number of chicks observed ranged from 11 (2009 SMH) to 36 (2010 SR) chicks per study area and year. Brood size (the number of chicks observed per successful late brood-rearing female) ranged from 3.3 chicks/female (SMH 2010) to 5.5 chicks/female (SMH 2009). During both study years, 
productivity (number of chicks per female in the marked sample) was greater within SR (0.56) than within the SMH $(0.38 ; 90 \% \mathrm{Cl}: 0.04-0.33)$.

Table 9. Brood-rearing parameters of females with successful nests located within the SRWRA and SMH study areas, Carbon County, Wyoming.

\begin{tabular}{|c|c|c|c|c|c|c|c|}
\hline $\begin{array}{l}\text { Study } \\
\text { Area }\end{array}$ & $\begin{array}{c}\text { \# of } \\
\text { monitored } \\
\text { females }\end{array}$ & $\begin{array}{c}\text { \# of } \\
\text { Successful } \\
\text { Nests }\end{array}$ & $\begin{array}{c}\text { Early } \\
\text { Brood- } \\
\text { Rearing } \\
\text { Success }\end{array}$ & $\begin{array}{c}\text { Late } \\
\text { Brood- } \\
\text { Rearing } \\
\text { Success }\end{array}$ & $\begin{array}{c}\text { \# of } \\
\text { total } \\
\text { chicks }\end{array}$ & $\begin{array}{l}\text { Productivity } \\
\text { (chicks per } \\
\text { brooding } \\
\text { female) }\end{array}$ & $\begin{array}{l}\text { Number of } \\
\text { females } \\
\text { successfully } \\
\text { reproducing }\end{array}$ \\
\hline & \multicolumn{7}{|c|}{2009} \\
\hline $\begin{array}{l}\text { Simpson } \\
\text { Ridge }\end{array}$ & 50 & 13 & $12(92 \%)$ & $9(75 \%)$ & 36 & 4 & $18 \%$ \\
\hline \multirow[t]{2}{*}{$\begin{array}{l}\text { Seven } \\
\text { Mile Hill }\end{array}$} & 25 & 6 & $6(100 \%)$ & $2(33 \%)$ & 11 & 5.5 & $8 \%$ \\
\hline & \multicolumn{7}{|c|}{2010} \\
\hline $\begin{array}{l}\text { Simpson } \\
\text { Ridge }\end{array}$ & 43 & 9 & $6(67 \%)$ & $\begin{array}{c}4(83 \%) \\
{[1]}\end{array}$ & 16 & 4 & $9 \%$ \\
\hline \multirow[t]{2}{*}{$\begin{array}{l}\text { Seven } \\
\text { Mile Hill }\end{array}$} & 39 & 6 & $6(100 \%)$ & $\begin{array}{c}4(83 \%) \\
{[1]}\end{array}$ & 13 & 3.25 & $10 \%$ \\
\hline & & \multicolumn{6}{|c|}{ Combined 2-Year (2009-2010) Totals } \\
\hline $\begin{array}{l}\text { Simpson } \\
\text { Ridge }\end{array}$ & 93 & 22 & $18(82 \%)$ & $13(72 \%)$ & 52 & 4 & $14 \pm 7.1 \%$ \\
\hline $\begin{array}{l}\text { Seven } \\
\text { Mile Hill }\end{array}$ & 64 & 12 & $\begin{array}{c}12 \\
(100 \%)\end{array}$ & $6(50 \%)$ & 24 & 4 & $9 \pm 7.2 \%$ \\
\hline
\end{tabular}

[ ] = number of females censored

Female Survival

During the study 53 of 116 radio marked birds died. Thirty-two mortalities were recorded within SRWRA (15 in 2009 and 17 in 2010) and 21 were recorded within SMH (8 in 2009 and 13 within 2010). Mortalities were located throughout the project areas (Figure 9). Although cause of death could not be determined for all mortalities, most appeared to have been killed by mammalian predators. During 2009 three radio-collared hens that did not exhibit any signs of trauma were submitted to the Wyoming State Veterinary Lab in Laramie, Wyoming to be examined for the presence of West Nile virus. Two of the three female sage-grouse tested positive for West Nile virus and all were located within the SRWRA study area. 


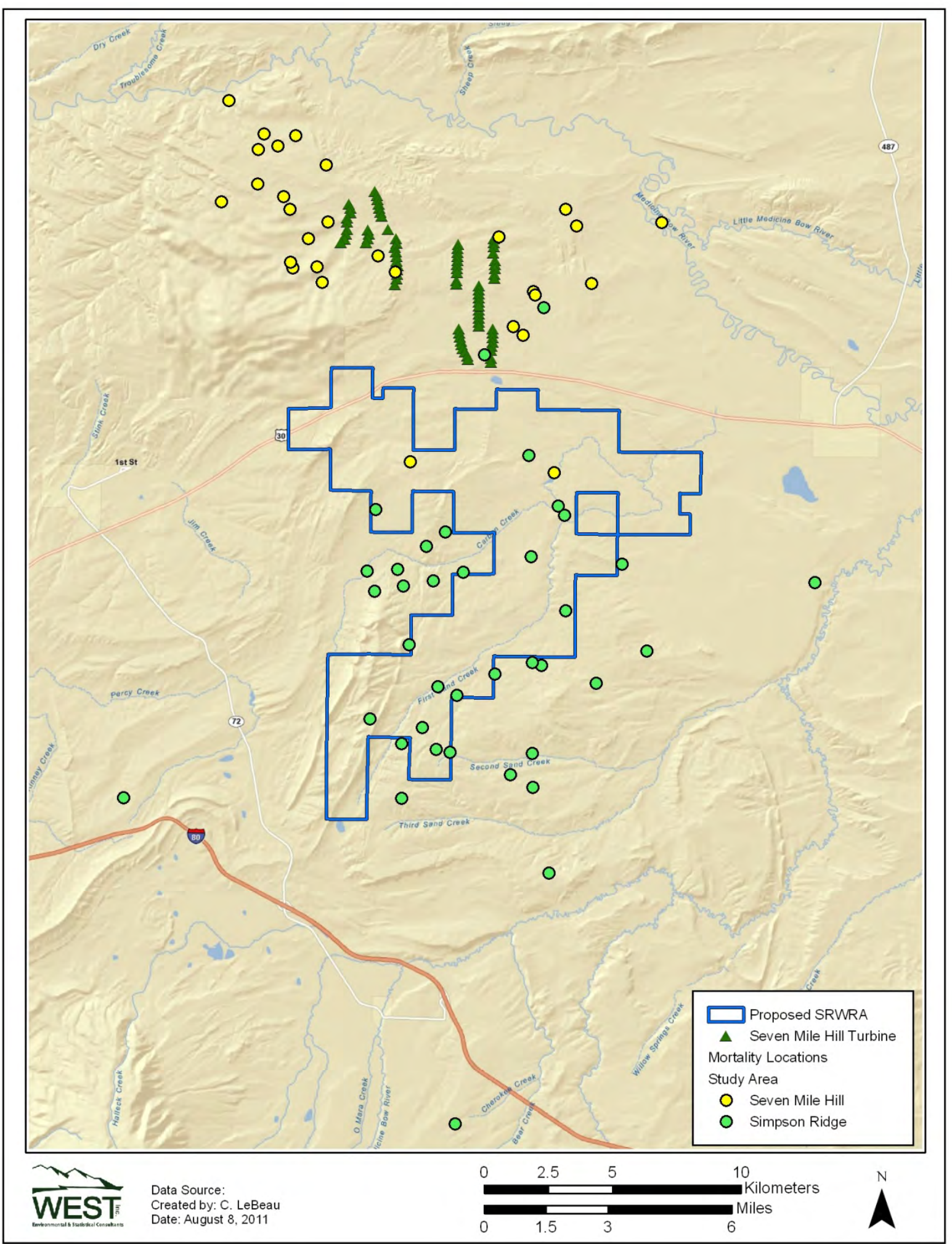

Figure 9. Observed female sage-grouse mortality locations within the Seven Mile Hill and Simpson Ridge study areas in Carbon County, Wyoming, 2009-2010. 
The median survival rate was similar for both study areas; however, survival at SRWRA (67\%) was slightly lower than that at SMH (69\%). The frequency of mortalities was similar within both study areas and years, where more than $50 \%$ of all mortalities were recorded during the spring months of April and May. However, $63 \%$ of all mortalities at SRWRA occurred in the summer period (June through September) during the 2009 study year. The fewest mortalities occurred during the fall and winter. The probability of survival decreased to around $40 \%$ towards the end of the study period (24 months; Figure 10). 

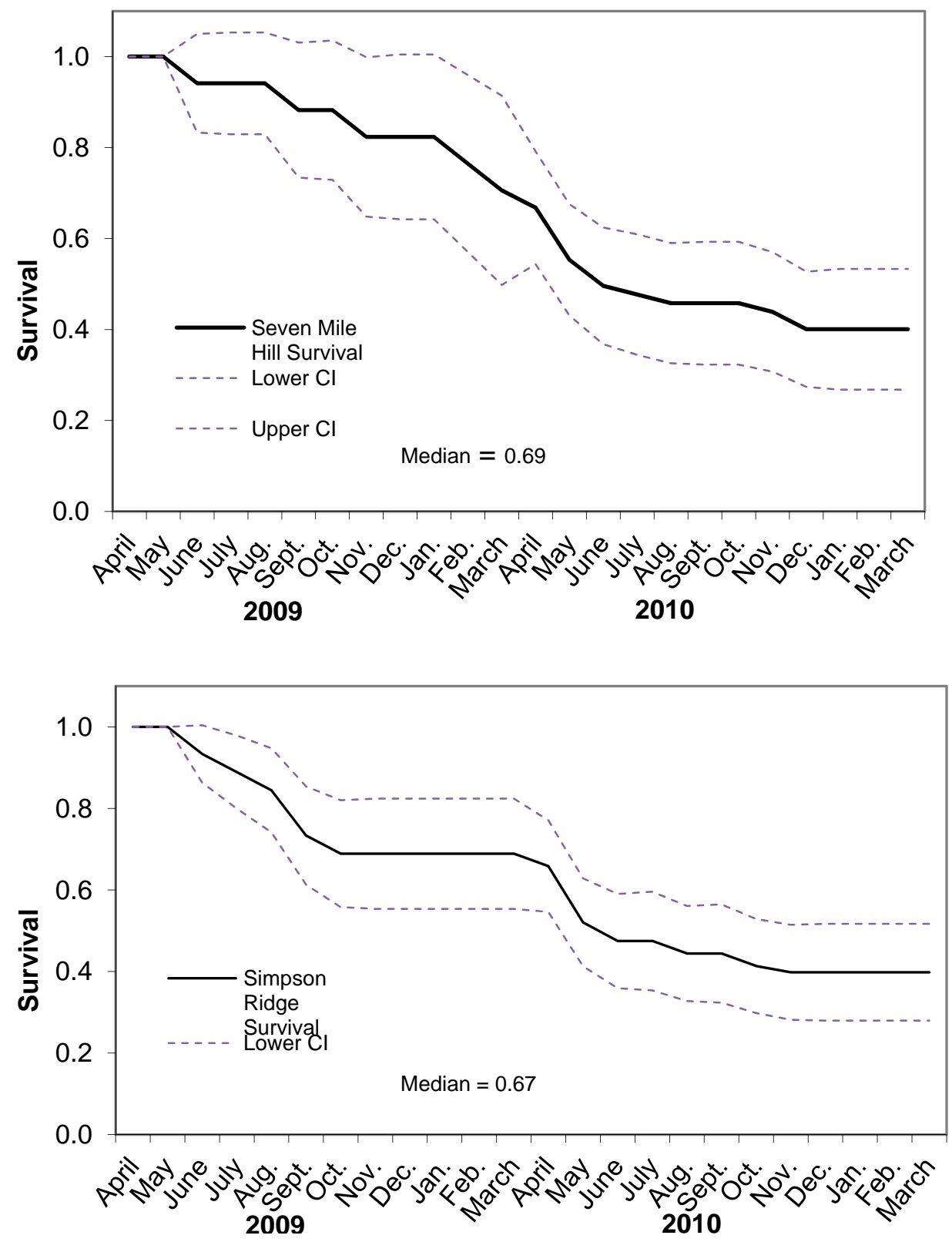

b

Figure 10. Kaplan-Meier survival estimation for monitored female sage-grouse within both study areas, Seven mile Hill (a) and Simpson Ridge (b) from April 2008 through March 2011.

\section{Sage-grouse Habitat Selection}

We monitored collared sage-grouse during 4 different biologically meaningful seasons, nesting, brood-rearing, summer, fall and winter. We recorded a total of 2,659 sage-grouse locations during these seasons (SMH, $n=1063$; SRWRA, $n=1,596$; Figure 11). Sage-grouse use was generally concentrated around leks within both study areas, especially during the nesting and brood-rearing periods. Sage-grouse captured within SRWRA tended to have a greater 
distribution compared to sage-grouse captured at $\mathrm{SMH}$. In addition, we observed sage-grouse utilizing habitats around the Seven Mile Hill turbines. We developed home ranges and relative probability of use maps to further understand the habitat selection patterns of sage-grouse within the SRWRA and SMH study areas. 


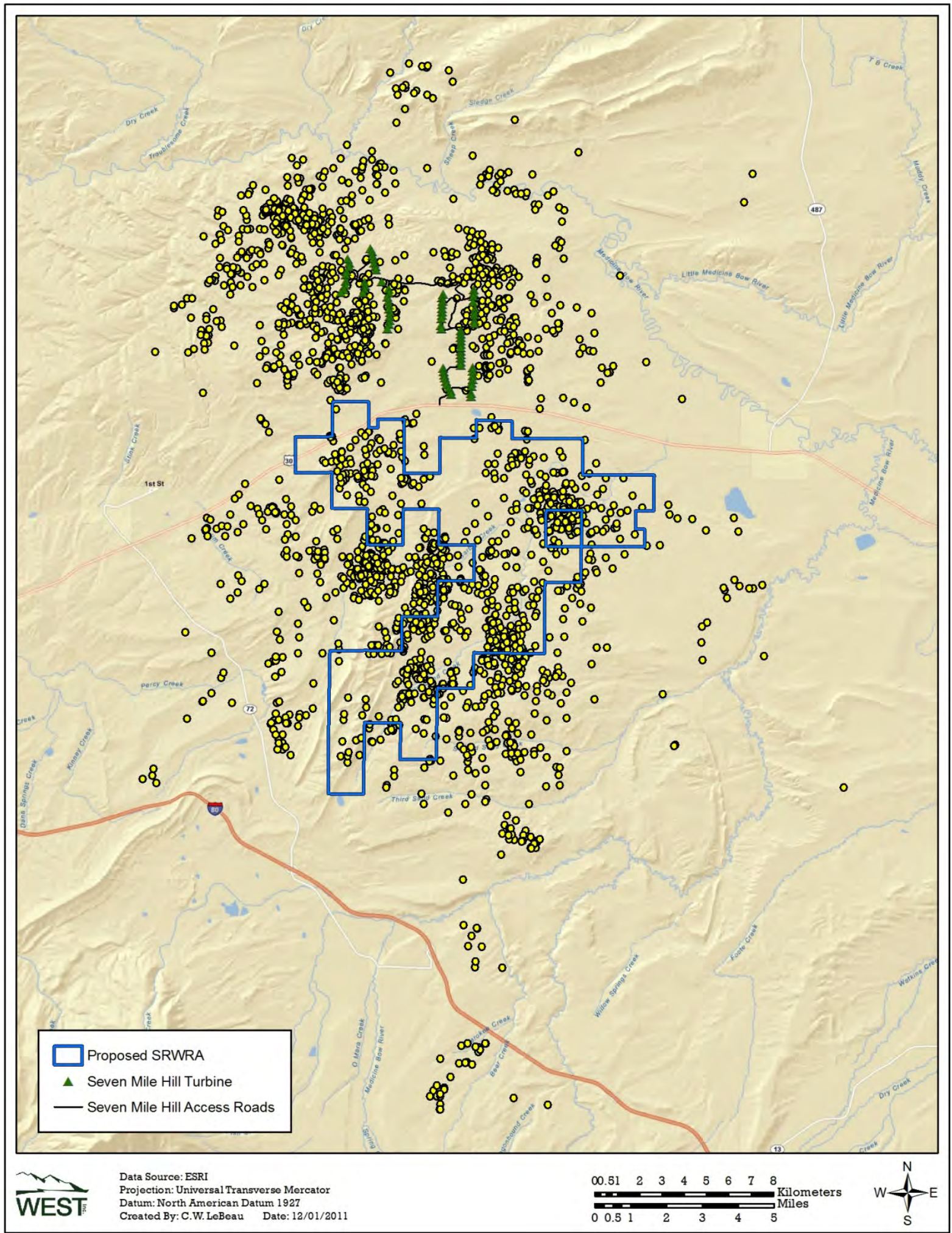

Figure 11. All sage-grouse locations observed within the Seven Mile Hill and Simpson Ridge study areas, Carbon County, Wyoming, 2009-2010. 


\section{Nest Occurrence}

A total of 94 nest locations ( $\mathrm{SMH}, n=42$; SRWRA, $n=52)$ were recorded and included in the home range and habitat selection analysis. One female captured at SRWRA nested within the $\mathrm{SMH}$ study area and was therefore removed from the habitat and home range analysis because we did not consider that female to be influenced by wind energy development. Utilization distributions (UDs) were compared between study areas. The proposed SRWRA project area was compared to a $1.6 \mathrm{~km}$ buffer area surrounding $\mathrm{SMH}$ turbines. Home range sizes were larger within the SRWRA study area compared to the SMH study area; however, the proportion of UDs within $1.6 \mathrm{~km}$ of the SMH turbines and the SRWRA project area were similar, with the $75 \%$ contours containing most of the project areas (Table 10; Figure 12).

Table 10. Estimated home range size $\left(\mathrm{km}^{2}\right)$ and estimated proportion within each project area for observed nest locations within both study areas in Carbon County, Wyoming.

\begin{tabular}{lrrrr}
\hline \hline & \multicolumn{2}{c}{ Seven Mile Hill } & \multicolumn{2}{c}{ Simpson Ridge } \\
Utilization Distribution & \multicolumn{1}{c}{ Total km } & \% within SMH & Total km & \% within SRWRA \\
\hline $95 \%$ Kernel Contour & 135.8 & $35.5 \%$ & 273.3 & $38.9 \%$ \\
$90 \%$ Kernel Contour & 105.6 & $42.4 \%$ & 210.2 & $44.4 \%$ \\
$75 \%$ Kernel Contour & 65.2 & $52.4 \%$ & 115.0 & $49.1 \%$ \\
\hline \hline
\end{tabular}




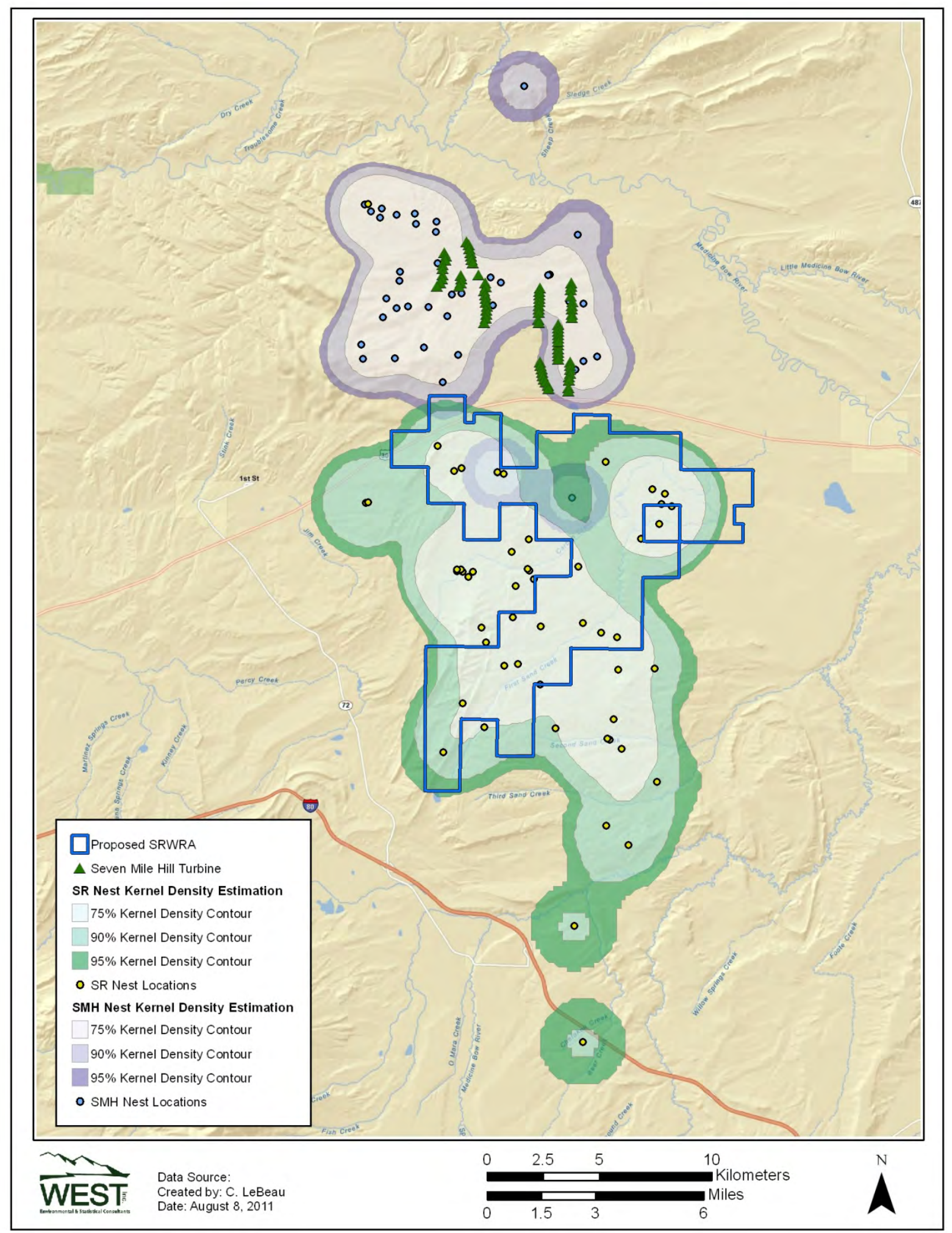

Figure 12. Utilization distributions of sage-grouse nest locations within the Seven Mile Hill and Simpson Ridge study areas in Carbon County, Wyoming, 2009-2010. 
Minimum convex polygons were placed around all SRWRA and SMH nest locations to delineate each study area and available habitat. The SRWRA MCP $\left(216.53 \mathrm{~km}^{2}\right)$ was 1.7-times larger than the MCP for SMH $\left(129.23 \mathrm{~km}^{2}\right)$. We generated 210 random available points within SMH and 260 within SRWRA MCP's.

We used a forward model selection procedure to determine top nest site selection models within both study areas. Top covariates differed among study areas. The top model for SMH included percent shrub and herbaceous cover, elevation, and distance to nearest lek and major road. The SRWRA model only included 2 covariates, shrub height $(\mathrm{cm})$ and distance to nearest transmission line. Both top models differed among other competing models by more than 2 AICC points (Table 11). Distance to nearest turbine was not included in the top nest site selection model for $\mathrm{SMH}$. However, because we are interested in the potential impacts of wind energy development on sage-grouse nest site selection, we added distance to nearest turbine to the top $\mathrm{SMH}$ model. Adding distance to nearest turbine to the top $\mathrm{SMH}$ model did not improve model fit $(\mathrm{AICC}=188.11)$ and did not have a significant slope $(\beta=-0.038 ; 90 \% \mathrm{Cl},-0.39$ to 0.26).

Table 11. Model fit statistics for greater sage-grouse nest occurrence at the Seven Mile Hill and Simpson Ridge study areas, Carbon County, Wyoming, 2009 and 2010. Models are listed according to the model best fitting the data and ranked by $(\triangle A I C c)$, the difference between the model with the lowest Akaike's Information Criterion for small samples (AICc) and the AICc for the current model. The value of the maximized log-likelihood function $(\log [L])$, the number of estimated parameters (K), and Akaike's weights (wi) for each model are also presented.

\begin{tabular}{|c|c|c|c|c|c|}
\hline Model & $\mathrm{K}$ & $\mathrm{AICc}$ & $\triangle \mathrm{AICC}$ & $w_{i}$ & $\log [\mathrm{L}]$ \\
\hline \multicolumn{6}{|c|}{ Seven Mile Hill } \\
\hline $\begin{array}{l}\text { shrub300, lek_dist, herbaceous300, elevation460, } \\
\text { dist_major_rds }\end{array}$ & 6 & 185.8 & 0.00 & 0.75 & -86.4 \\
\hline shrub300, lek_dist, herbaceous300, elevation460 & 5 & 188.2 & 2.33 & 0.23 & -88.7 \\
\hline shrub300, lek_dist, herbaceous300 & 4 & 197.1 & 11.22 & 0.00 & -94.3 \\
\hline shrub300, lek_dist & 3 & 203.0 & 17.13 & 0.00 & -98.4 \\
\hline shrub300 & 2 & 211.8 & 26.00 & 0.00 & -103.9 \\
\hline \multicolumn{6}{|c|}{ Simpson Ridge } \\
\hline shrub_hgt300, dist_tline & 3 & 267.4 & 0.00 & 0.97 & -130.6 \\
\hline shrub_hgt300 & 2 & 274.2 & 6.87 & 0.03 & -135.1 \\
\hline
\end{tabular}

The estimated relative probability of sage-grouse nest site selection within SMH was approximately $84 \%(90 \% \mathrm{Cl}, 40$ to $165 \%)$ higher with every 1-unit increase in percent shrub cover within a $0.30 \mathrm{~km}$ radius buffer (Table 12; Figure 13). In addition, nest site selection within $\mathrm{SMH}$ was approximately $39 \%$ lower with every 1-unit increase from nearest occupied lek $(90 \%$ $\mathrm{Cl},-55$ to $-28 \%$; Table 12; Figure 13). Nest site selection increased by $16 \%$ with every 1-unit increase in distance to a major road $(90 \% \mathrm{Cl}, 4$ to $29 \%$; Table 12; Figure 13). Lastly, percent 
herbaceous cover was included in the top model; however, the estimated parameters were not significant (Table 12; Figure 13).

Shrub height and distance to transmission line were included in the top SRWRA model. The estimated relative probability of selection increased by approximately $10 \%$ for every 1-unit increase in shrub height within a $0.30 \mathrm{~km}$ radius buffer, but decreased by approximately $15 \%$ for every 1-unit increase in distance from nearest transmission line $(90 \% \mathrm{Cl}, 5.0$ to $16 \%$ and -23 to $-7.9 \%$, respectively; Table 12, Figure 14).

Lastly, the 5-fold validation method used on the top model for each study area indicated that the $\mathrm{SMH}$ top model had good overall predictive ability (average $r=0.67$ ); however, the predictive ability for the SR top model was lower (average $r=0.49$ ), but still better than random chance.

Table 12. Selection ratios and slope coefficients for covariates in the sage-grouse top nest site occurrence model for the Seven Mile Hill and Simpson Ridge study areas in Carbon County, Wyoming, USA, 2009 and 2010. Selection ratios measure the multiplicative change in relative probability of selection when a covariate changes by 1 unit, assuming all other covariates remain constant. Selection ratios were not calculated for covariates involved with a quadratic effect because they were dependent on values of other variables.

\begin{tabular}{|c|c|c|c|c|c|c|}
\hline \multirow{2}{*}{ Description } & \multirow{2}{*}{ Coefficient } & \multicolumn{2}{|c|}{ 90\% Confidence Interval } & \multirow{2}{*}{$\begin{array}{l}\text { Selection } \\
\text { Ratio }\end{array}$} & \multicolumn{2}{|c|}{$90 \%$ Confidence Interval } \\
\hline & & Lower & Upper & & Lower & Upper \\
\hline \multicolumn{7}{|l|}{ Seven Mile Hill } \\
\hline (Intercept) & -52.56 & & & & & \\
\hline shrub300 & 0.61 & 0.34 & 0.97 & 83.6 & 40.5 & 165 \\
\hline lek_dist & -0.49 & -0.80 & -0.34 & -38.8 & -55.1 & -28.5 \\
\hline herbaceous 300 & 0.20 & -0.04 & 0.42 & 22.2 & -4.34 & 51.9 \\
\hline elevation460 & 0.02 & 0.01 & 0.03 & 2.12 & 1.21 & 3.41 \\
\hline dist_major_rds & 0.15 & 0.04 & 0.26 & 16.4 & 4.30 & 29.2 \\
\hline \multicolumn{7}{|l|}{ Simpson Ridge } \\
\hline (Intercept) & 7.23 & & & & & \\
\hline shrub_hgt300 & 0.09 & 0.05 & 0.15 & 10.1 & 5.02 & 16.2 \\
\hline dist_tline & -0.15 & -0.27 & -0.08 & -15.3 & -23.4 & -7.90 \\
\hline
\end{tabular}



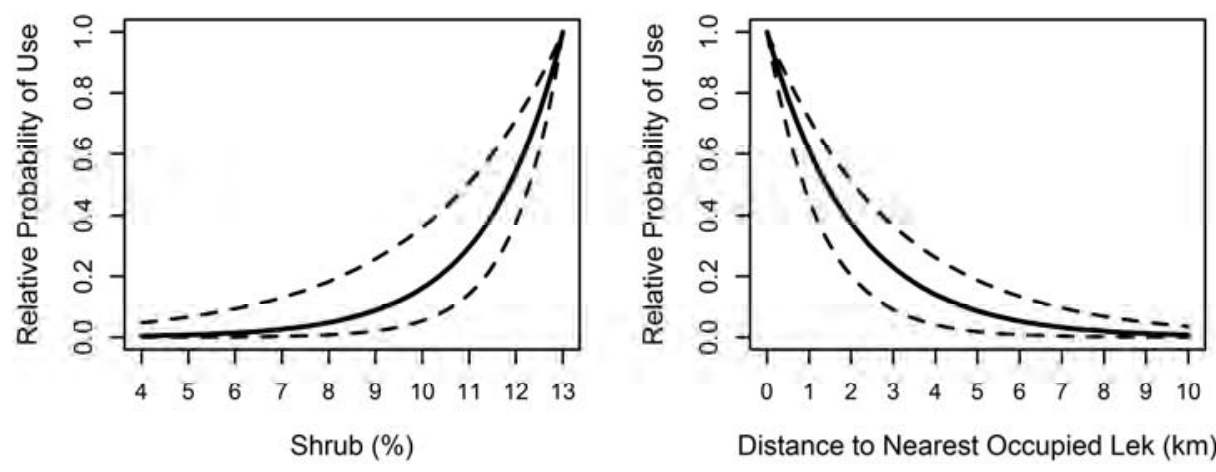

Distance to Nearest Occupied Lek $(\mathrm{km})$
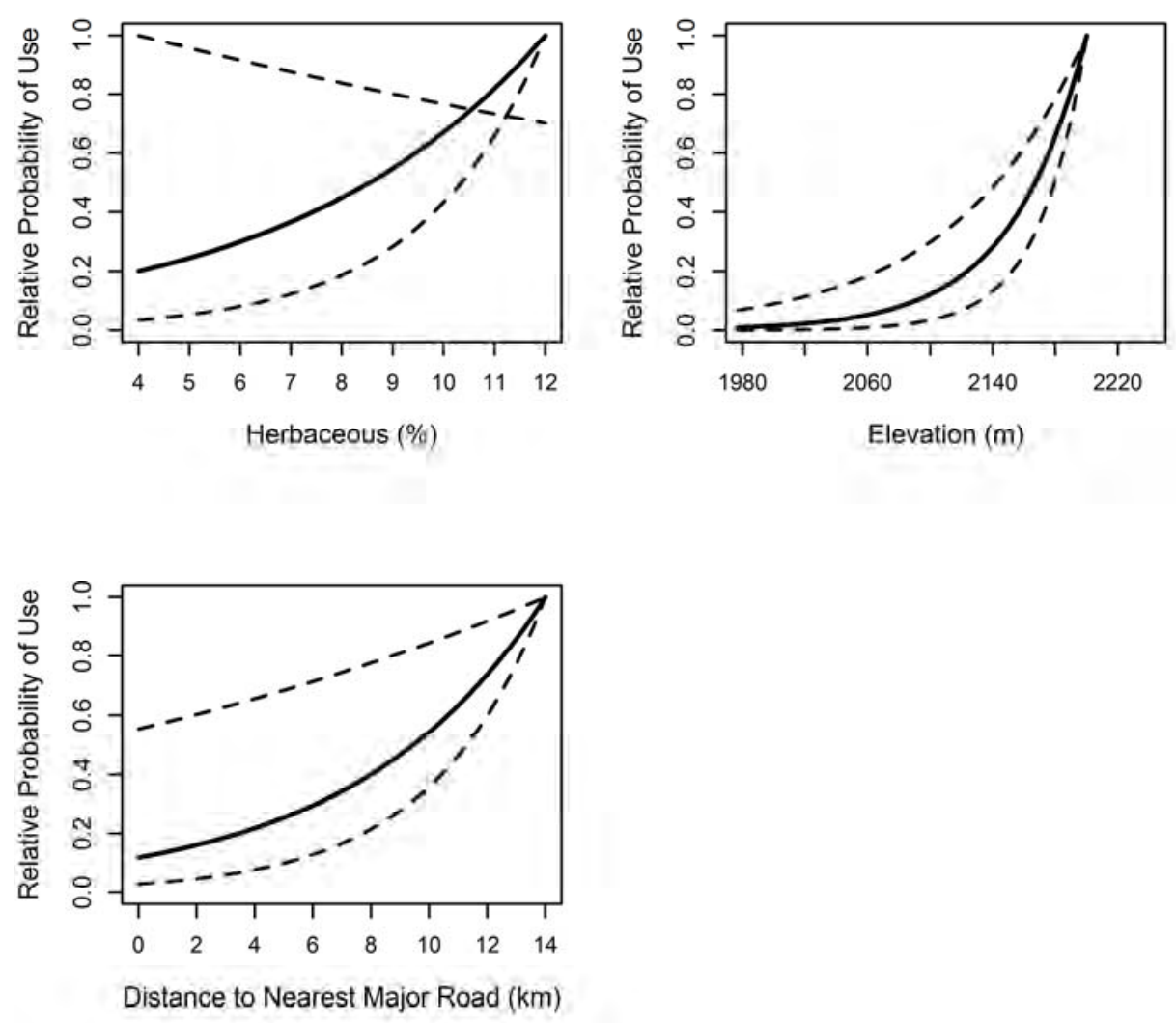

Figure 13. Relative probability of sage-grouse nest site occurrence and $90 \% \mathrm{Cl}$ within the Seven Mile Hill study area as a function of top model covariates, Carbon County, Wyoming, 2009 and 2010. Variables that are not plotted were held constant at their median value. 

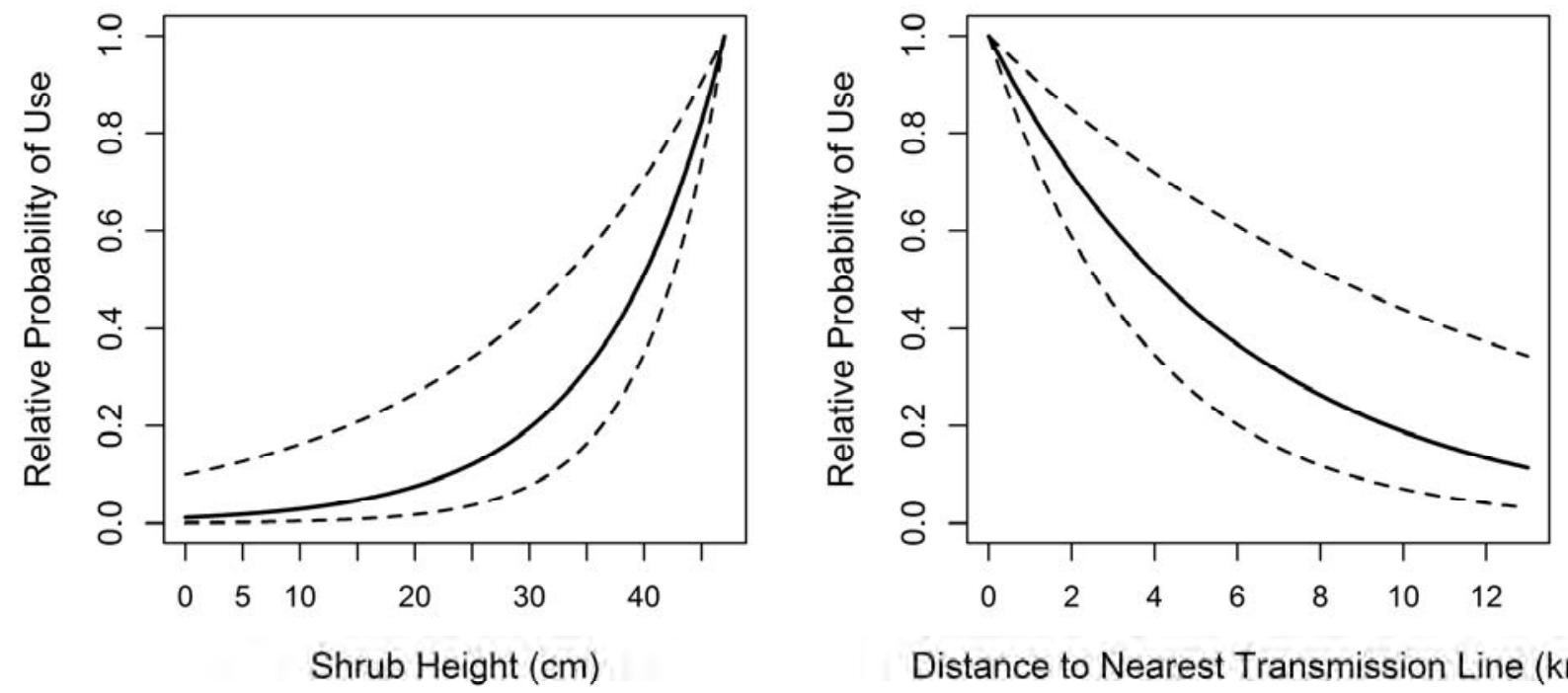

Distance to Nearest Transmission Line $(\mathrm{km})$

Figure 14. Relative probability of sage-grouse nest site occurrence and $90 \% \mathrm{Cl}$ within the Simpson Ridge study area as a function of top model covariates, Carbon County, Wyoming, 2009 and 2010. Variables that are not plotted were held constant at their median value.

Similar to the home range analysis, the proportion of predictive bins within $1.6 \mathrm{~km}$ of SMH turbines and within the SRWRA project area were determined to identify high probability of use areas within each project. RSF values were equally divided into 5 quantile predictive bins ranging from low to high predictive use. The majority of habitat within the SMH study (68.3\%) has a medium-high probability of nest occurrence and $26.2 \%$ was classified as high (Table 13 , Figure 15). However, $57.0 \%$ of the habitat within the SRWRA study has medium probability of nest occurrence, followed by medium-high (46.1\%) and medium-low (37.5\%; Table 13, Figure 16).

Table 13. The proportion of nest occurrence predictive bin values within $1.6 \mathrm{~km}$ of Seven Mile Hill turbines and within the Simpson Ridge project area.

\begin{tabular}{lrr}
\hline \hline Predictive Bin (RSF values) & Proportion within SMH & Proportion within SRWRA \\
\hline Low & $14.7 \%$ & $0.1 \%$ \\
Medium - Low & $35.7 \%$ & $37.5 \%$ \\
Medium & $57.7 \%$ & $57.0 \%$ \\
Medium-High & $68.3 \%$ & $46.1 \%$ \\
High & $26.2 \%$ & $35.1 \%$ \\
\hline \hline
\end{tabular}




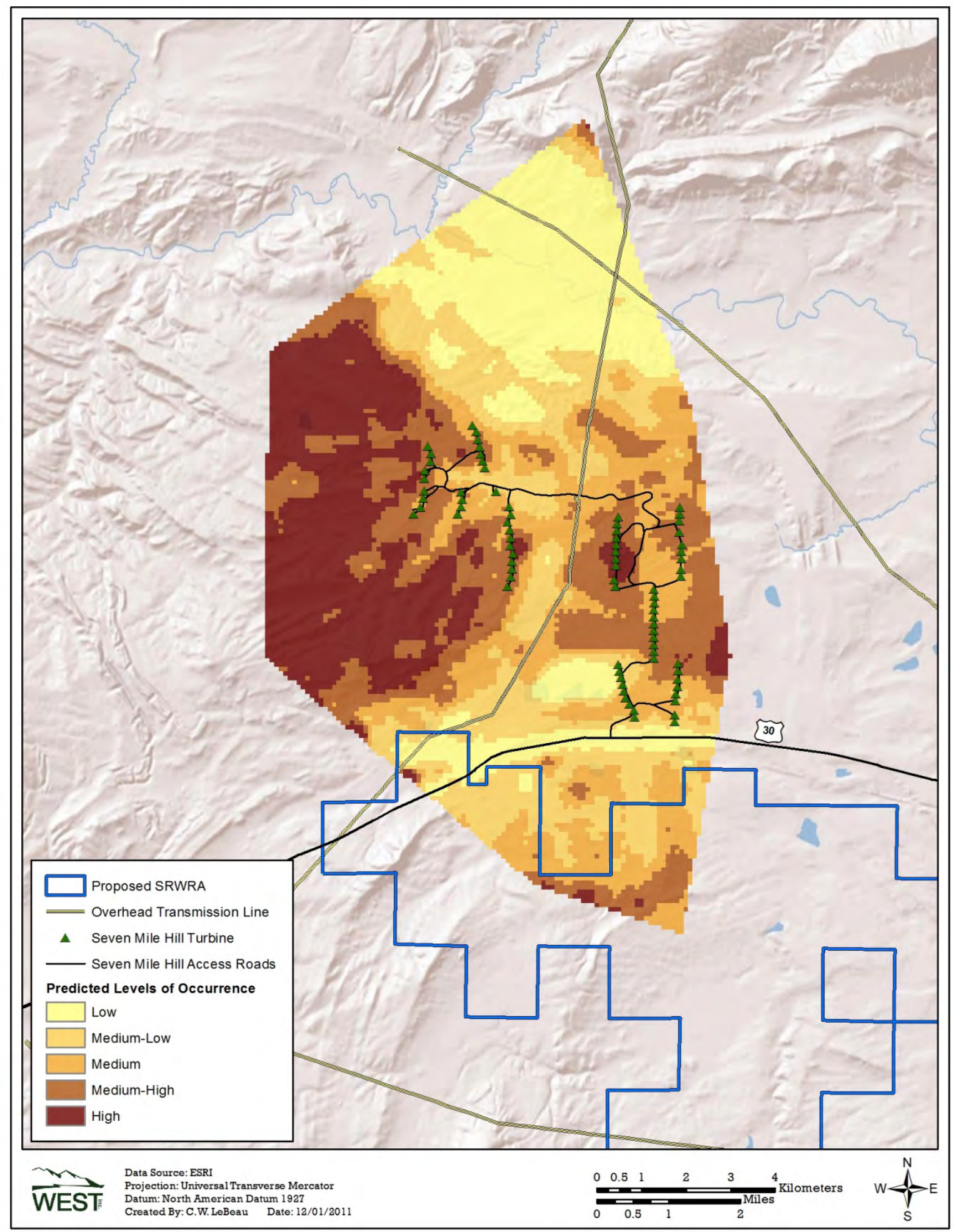

Figure 15. Predicted nesting habitat used by sage-grouse within the Seven Mile Hill study area, Carbon County, Wyoming, 2009 and 2010. 


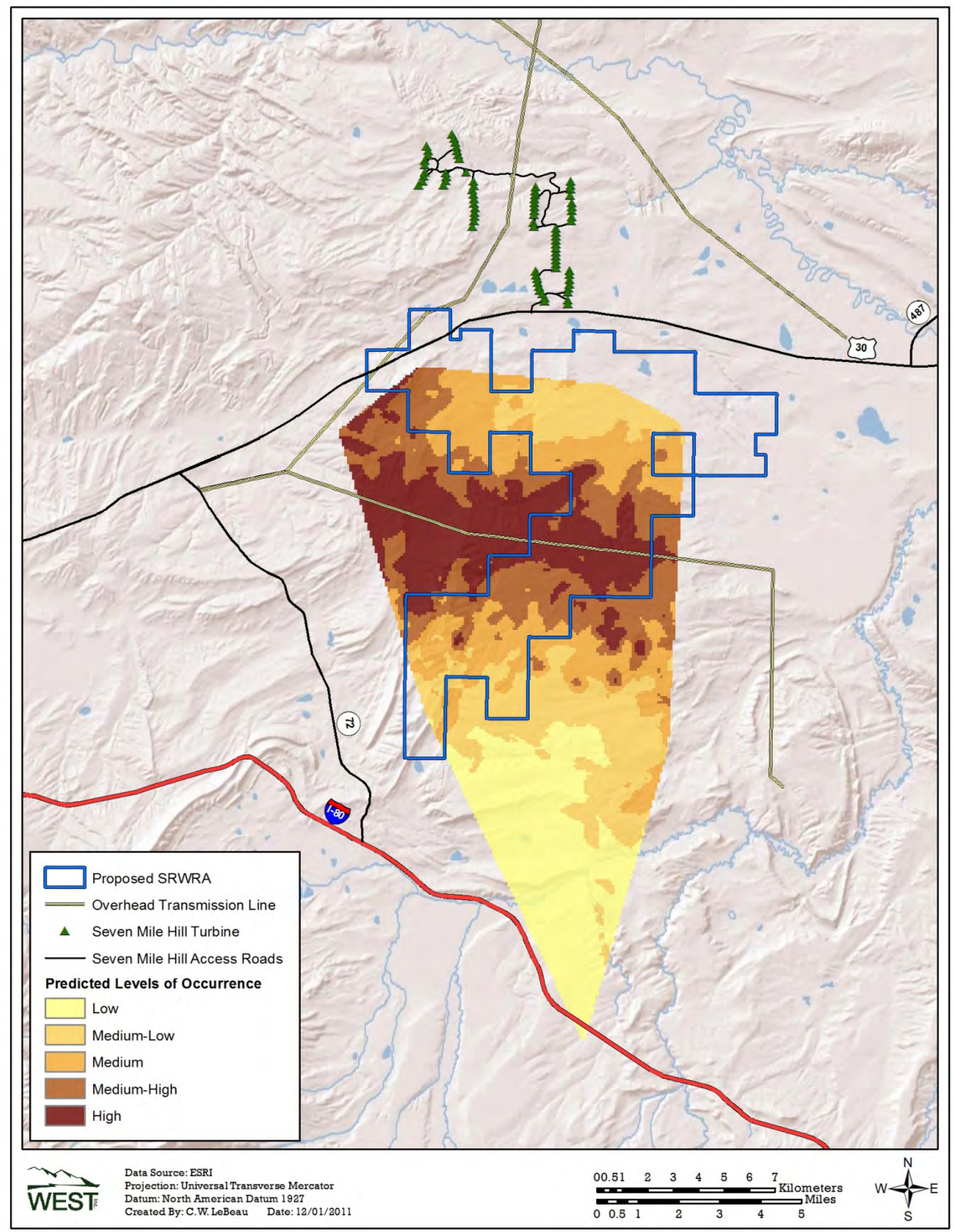

Figure 16. Predicted nesting habitat used by sage-grouse within the Simpson Ridge study area, Carbon County, Wyoming, 2009 and 2010. 


\section{Brood-Rearing Occurrence}

A total of 347 brood-rearing locations $(\mathrm{SMH}, n=138$; SRWRA, $n=204$ ) were recorded and included in the home range and habitat selection analyses. Utilization distributions were compared between study areas. The proposed SRWRA project area was compared to a $1.6 \mathrm{~km}$ buffer around SMH turbines. Home range sizes were highest within the SRWRA study area compared to the SMH study area; however, the proportion of utilization distributions within 1.6 $\mathrm{km}$ of the SMH turbines and the SRWRA project area were similar, with the $75 \%$ contours containing most of the project areas (Table 14; Figure 17)

Table 14. Estimated home range size $\left(\mathrm{km}^{2}\right)$ and estimated proportion within each project area for observed brood-rearing locations within both study areas in Carbon County, Wyoming.

\begin{tabular}{lrrrr}
\hline \hline & \multicolumn{2}{c}{ Seven Mile Hill } & \multicolumn{2}{c}{ Simpson Ridge } \\
Utilization Distribution & Total km & \% within SMH & Total km & \% within SRWRA \\
\hline $95 \%$ Kernel Contour & 89.0 & $34.1 \%$ & 228.4 & $32.6 \%$ \\
$90 \%$ Kernel Contour & 59.1 & $38.6 \%$ & 169.6 & $34.9 \%$ \\
$75 \%$ Kernel Contour & 23.5 & $41.6 \%$ & 87.7 & $49.3 \%$ \\
\hline \hline
\end{tabular}




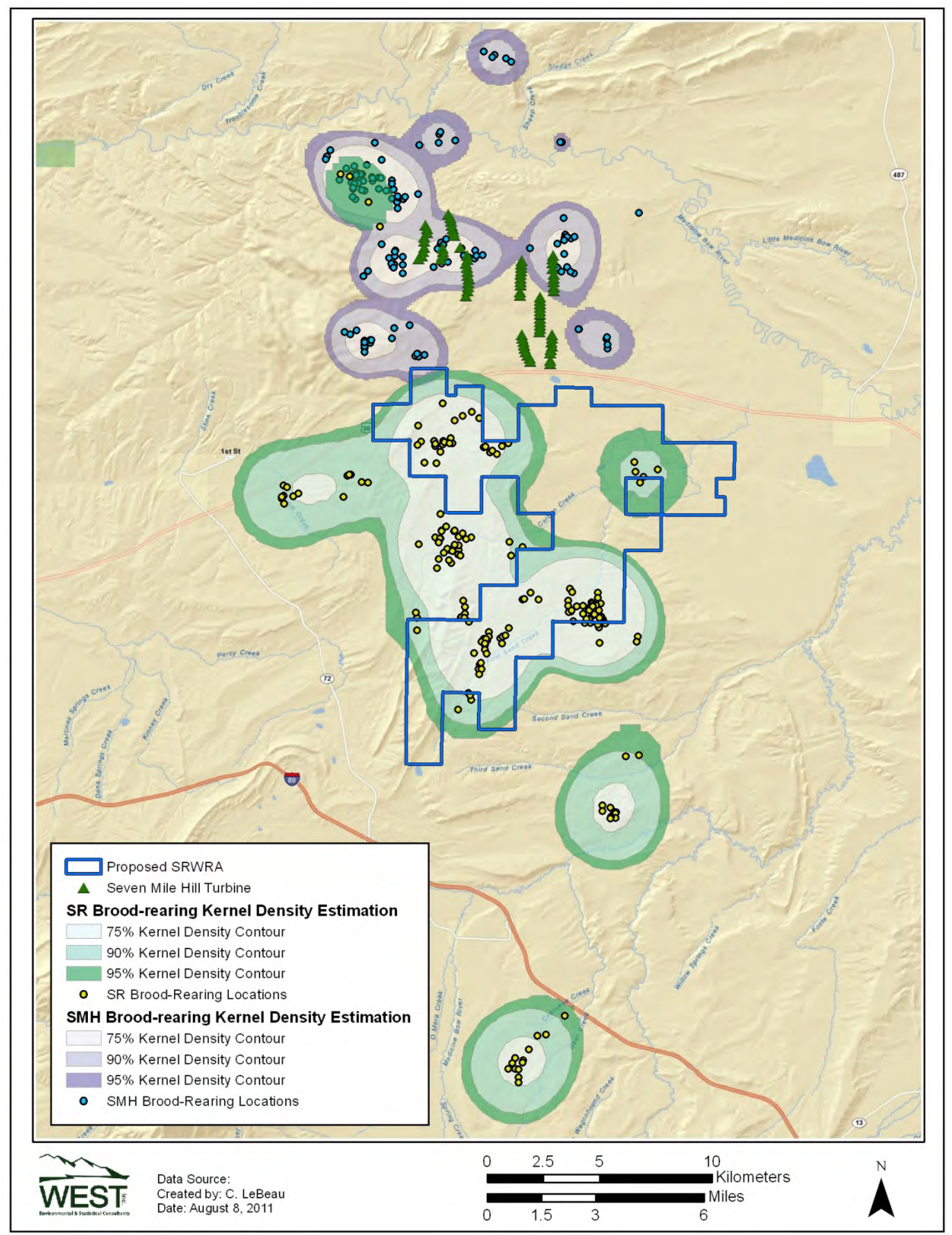

Figure 17. Utilization distributions of sage-grouse brood-rearing locations within the Seven Mile Hill and Simpson Ridge study areas, Carbon County, Wyoming, 2009-2010. 
To define the available brood-rearing habitat, MCPs were placed around all SRWRA and SMH brood-rearing locations to delineate each study area. The MCP for SRWRA $\left(650 \mathrm{~km}^{2}\right)$ was approximately 5.2-times larger than the MCP for SMH $\left(126 \mathrm{~km}^{2}\right)$. We generated 695 available locations within SMH and 1,045 within SRWRA.

Habitat covariates and anthropogenic variables included in the top models differed between both study areas; however, percent bare ground and herbaceous cover were included in the top models for both study areas. The quadratic form of distance to nearest transmission line, elevation, and percent shrub cover were included in the top SMH brood-rearing model (Table 15). Similar to $\mathrm{SMH}$, distance to transmission line was also included in the SRWRA top model; however, it retained its linear form. Distance to major road and percent litter cover were also included in the top SRWRA model. The next approximating model observed at both study areas was greater than approximately $3 \triangle \mathrm{AICc}$ points from the top model (Table 15). The covariate of interest, distance to nearest turbine, was not included in the top model for $\mathrm{SMH}$; however, it did compete with all other covariates during the forward model selection procedure. Adding distance to nearest turbine to the top model within SMH did not improve model fit (i.e., AICc score $=635.7 ; \beta=0.12 ; 90 \% \mathrm{Cl},-0.39$ to 0.61 ).

Table 15. Model fit statistics for greater sage-grouse nest occurrence at the Seven Mile Hill and Simpson Ridge study areas, Carbon County, Wyoming, 2009 and 2010. Models are listed according to the model best fitting the data and ranked by $(\triangle A I C c)$, the difference between the model with the lowest Akaike's Information Criterion for small samples (AICc) and the AICc for the current model. The value of the maximized log-likelihood function $(\log [L])$, the number of estimated parameters (K), and Akaike's weights (wi) for each model are also presented.

\begin{tabular}{|c|c|c|c|c|c|}
\hline Model & $\mathrm{K}$ & $\mathrm{AICc}$ & $\triangle \mathrm{AICc}$ & $w_{i}$ & $\log [\mathrm{L}]$ \\
\hline \multicolumn{6}{|l|}{$\begin{array}{l}\text { Seven Mile Hill } \\
\end{array}$} \\
\hline $\begin{array}{l}\text { dist_tline, dist_tline }{ }^{2} \text {, bare-ground } 460 \text {, herbaceous } 1000 \text {, } \\
\text { elevation1000, shrub1000 }\end{array}$ & 7 & 635.1 & 0.00 & 0.91 & -309.9 \\
\hline $\begin{array}{l}\text { dist_tline, dist_tline }{ }^{2} \text {, bare-ground } 460 \text {, herbaceous } 1000 \text {, } \\
\text { elevation } 1000\end{array}$ & 6 & 640.0 & 4.92 & 0.08 & -313.5 \\
\hline dist_tline, dist_tline ${ }^{2}$, bare-ground460, herbaceous 1000 & 5 & 644.5 & 9.45 & 0.01 & -316.9 \\
\hline dist_tline, dist_tline ${ }^{2}$, bare-ground 460 & 4 & 655.3 & 20.22 & 0.00 & -323.4 \\
\hline dist_tline, dist_tline ${ }^{2}$ & 3 & 693.1 & 57.99 & 0.00 & -343.4 \\
\hline \multicolumn{6}{|l|}{ Simpson Ridge } \\
\hline $\begin{array}{l}\text { dist_tline, litter460, dist_major_rds, herbaceous1000, } \\
\text { bare-ground300 }\end{array}$ & 6 & 1049.8 & 0.00 & 0.81 & -518.4 \\
\hline dist_tline, litter460, dist_major_rds, herbaceous 1000 & 5 & 1052.9 & 3.15 & 0.17 & -521.1 \\
\hline dist_tline, litter460, dist_major_rds & 4 & 1056.9 & 7.06 & 0.02 & -524.2 \\
\hline dist_tline, litter460 & 3 & 1061.0 & 11.19 & 0.00 & -527.4 \\
\hline dist_tline & 2 & 1065.9 & 16.08 & 0.00 & -530.9 \\
\hline
\end{tabular}


The estimated relative probability sage-grouse selecting brood rearing habitat within $\mathrm{SMH}$ increased as distance from nearest overhead transmission line increased up to $4.7 \mathrm{~km}$, then declined (Table 16; Figure 18). Brood-rearing habitat selection decreased by approximately $13 \%$ for every 1-unit increase in percent bare ground within a $0.46 \mathrm{~km}$ radius buffer $(90 \% \mathrm{Cl}$, 17.5 to $-8.6 \%$; Table 16; Figure 18). In addition, brood-rearing habitat selection increased by $97 \%$ and $53 \%$ for every 1-unit increase in percent herbaceous and shrub cover within a $1 \mathrm{~km}$ radius buffer ( $90 \% \mathrm{Cl}, 28$ to $260 \%$ and 1.1 to 158\%), respectively (Table 16; Figure 18).

The SRWRA brood-rearing data supported a model that included distance to nearest transmission line and major road and percent herbaceous cover; however, substantial variability of these covariates, indicated by the inclusion of 0.0 within the Cl's, existed across individual birds (Table 16; Figure 19). The estimated relative probability of selecting brood-rearing habitat within SRWRA decreased by 3.3\% for every 1-unit increase in percent bare ground cover within $0.30 \mathrm{~km}$ radius buffer $(90 \% \mathrm{Cl},-5.6$ to $-1.12 \%$; Table 16; Figure 19). However, brood-rearing habitat selection increased by $11 \%$ for every 1-unit increase in percent litter cover within 0.46 $\mathrm{km}$ radius buffer $(90 \% \mathrm{Cl}, 1.9$ to $20 \%$; Table 16; Figure 19). 
Table 16. Selection ratios and slope coefficients for covariates in the sage-grouse top brood-rearing occurrence model for the Seven Mile Hill and Simpson Ridge study areas in Carbon County, Wyoming, USA, 2009 and 2010. Selection ratios measure the multiplicative change in relative probability of selection when a covariate changes by 1 unit, assuming all other covariates remain constant. Selection ratios were not calculated for covariates involved with a quadratic effect because they were dependent on values of other variables.

\begin{tabular}{|c|c|c|c|c|c|c|}
\hline \multirow{2}{*}{ Description } & \multirow{2}{*}{ Coefficient } & \multicolumn{2}{|c|}{ 90\% Confidence Interval } & \multirow{2}{*}{$\begin{array}{l}\text { Selection } \\
\text { Ratio }\end{array}$} & \multicolumn{2}{|c|}{ 90\% Confidence Interval } \\
\hline & & Lower & Upper & & Lower & Upper \\
\hline \multicolumn{7}{|l|}{ Seven Mile Hill } \\
\hline (Intercept) & 19.25 & & & & & \\
\hline dist_tline & 1.12 & NA & NA & NA & NA & NA \\
\hline dist_tline ${ }^{2}$ & -0.12 & -0.25 & -0.03 & NA & NA & NA \\
\hline bare-ground 460 & -0.14 & -0.19 & -0.09 & -13.1 & -17.5 & -8.61 \\
\hline herbaceous 1000 & 0.68 & 0.25 & 1.28 & 96.5 & 27.8 & 260 \\
\hline elevation1000 & -0.01 & -0.02 & 0.00 & -1.09 & -2.28 & -0.14 \\
\hline shrub1000 & 0.42 & 0.01 & 0.95 & 52.7 & 1.07 & 158 \\
\hline \multicolumn{7}{|l|}{ Simpson Ridge } \\
\hline (Intercept) & -0.69 & & & & & \\
\hline dist_tline & -0.12 & -0.39 & 0.08 & -11.0 & -32.2 & 7.89 \\
\hline litter460 & 0.11 & 0.02 & 0.19 & 11.2 & 1.92 & 20.4 \\
\hline dist_major_rds & 0.09 & -0.05 & 0.29 & 9.18 & -4.77 & 33.6 \\
\hline herbaceous 1000 & -0.10 & -0.30 & 0.01 & -9.20 & -25.9 & 1.40 \\
\hline bare-ground300 & -0.03 & -0.06 & -0.01 & -3.25 & -5.59 & -1.12 \\
\hline
\end{tabular}




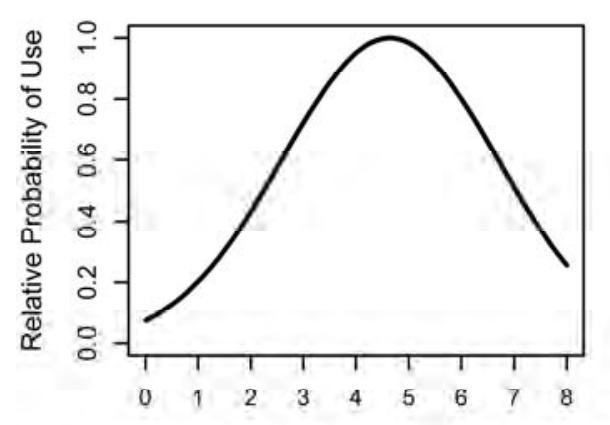

Distance to Nearest Transmission Line $(\mathrm{km})$
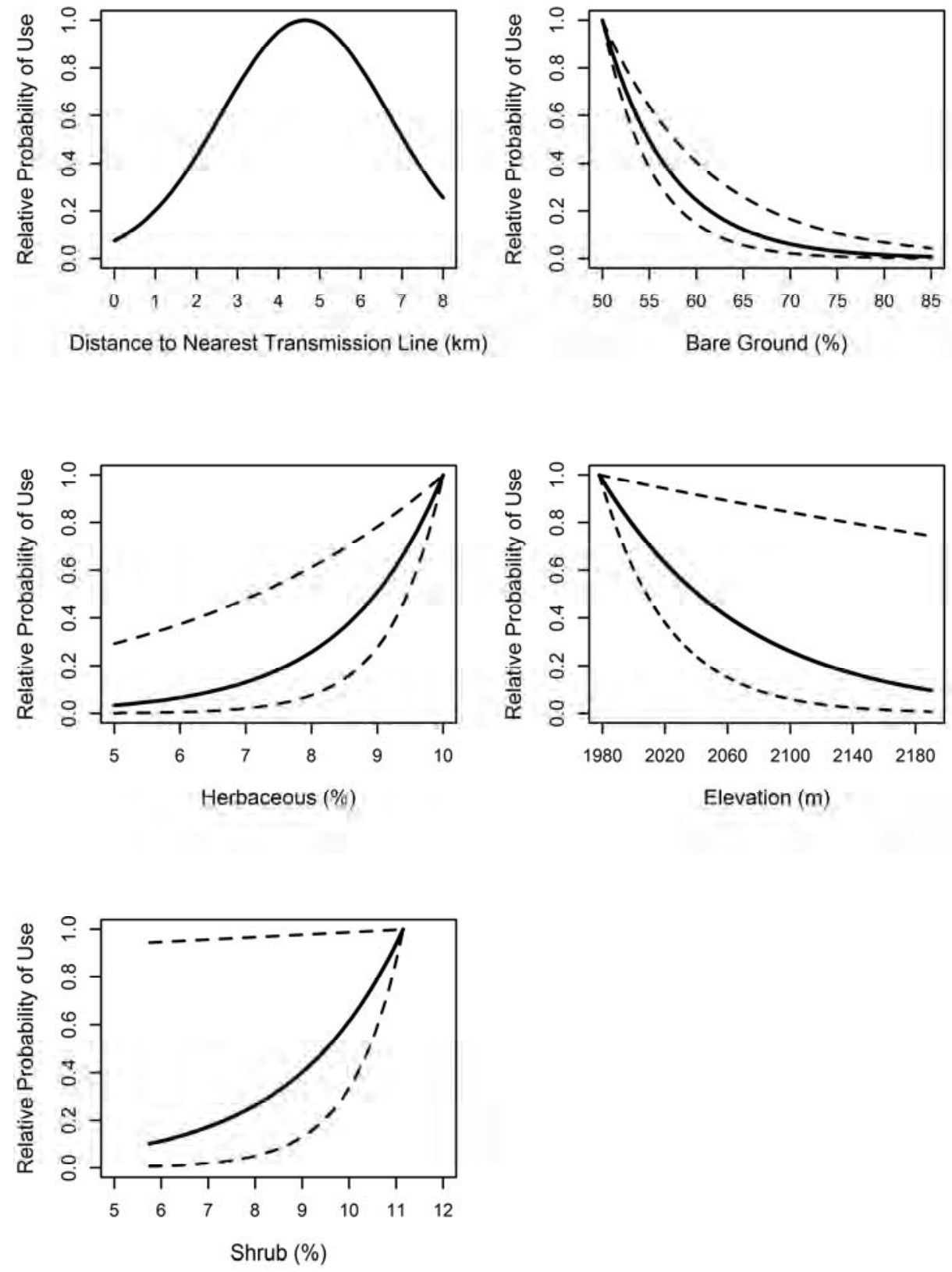

Figure 18. Relative probability of sage-grouse brood-rearing occurrence and $90 \%$ $\mathrm{Cl}$ within the Seven Mile Hill study area as a function of top model covariates, Carbon County, Wyoming, 2009 and 2010. Variables that are not plotted were held constant at their median value. 


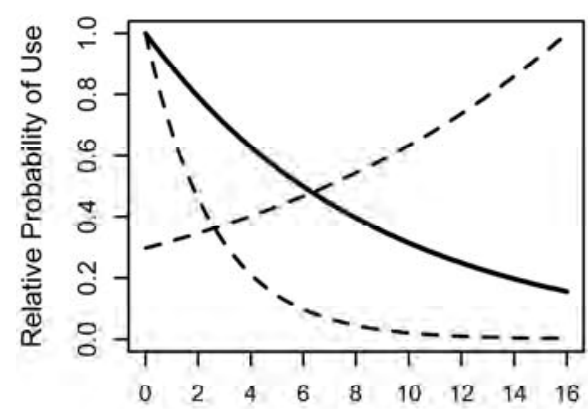

Distance to Nearest Transmission Line $(\mathrm{km})$

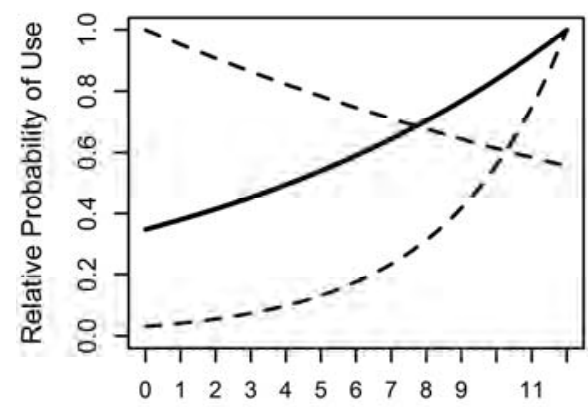

Distance to Nearest Major Road $(\mathrm{km})$

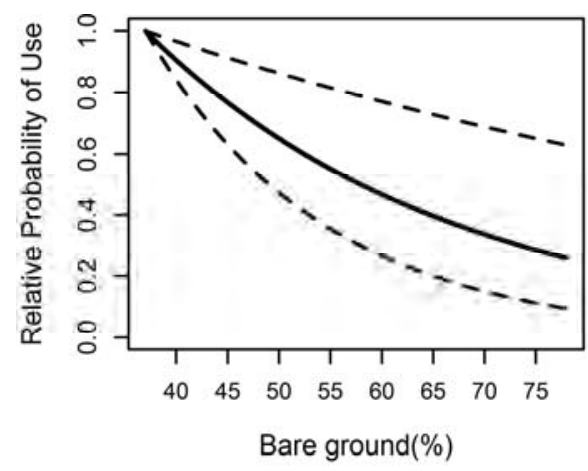

Figure 19. Relative probability of sage-grouse brood-rearing occurrence and $90 \%$ $\mathrm{Cl}$ within the Simpson Ridge study area as a function of top model covariates, Carbon County, Wyoming, 2009 and 2010. Variables that are not plotted were held constant at their median value. 
Similar to the home range analysis, the proportion of predictive bins within $1.6 \mathrm{~km}$ of SMH turbines and within the SRWRA project area were determined to identify high probability of use areas within each project area. RSF values were equally divided into 5 quantile predictive bins ranging from low to high predictive use. The proportion of predicted levels of habitat use within $1.6 \mathrm{~km}$ of turbines was similar, ranging from $33.2 \%$ (high) to $45.9 \%$ (medium-high; Table 17 , Figure 20). Similar to $\mathrm{SMH}$, the proportion of all medium-high and high habitats within SRWRA was $44.3 \%$ and $38.5 \%$, respectively (Table 17 , Figure 21 ).

Table 17. The proportion of brood-rearing predictive bin values within 1-mile of Seven Mile Hill turbines and within the Simpson Ridge Wind project area.

\begin{tabular}{lrr}
\hline \hline Predictive Bin (RSF values) & Proportion within SMH & Proportion within SRWRA \\
\hline Low & $39.6 \%$ & $0.2 \%$ \\
Medium - Low & $38.3 \%$ & $16.1 \%$ \\
Medium & $39.6 \%$ & $36.4 \%$ \\
Medium-High & $45.9 \%$ & $44.3 \%$ \\
High & $33.2 \%$ & $38.5 \%$ \\
\hline \hline
\end{tabular}




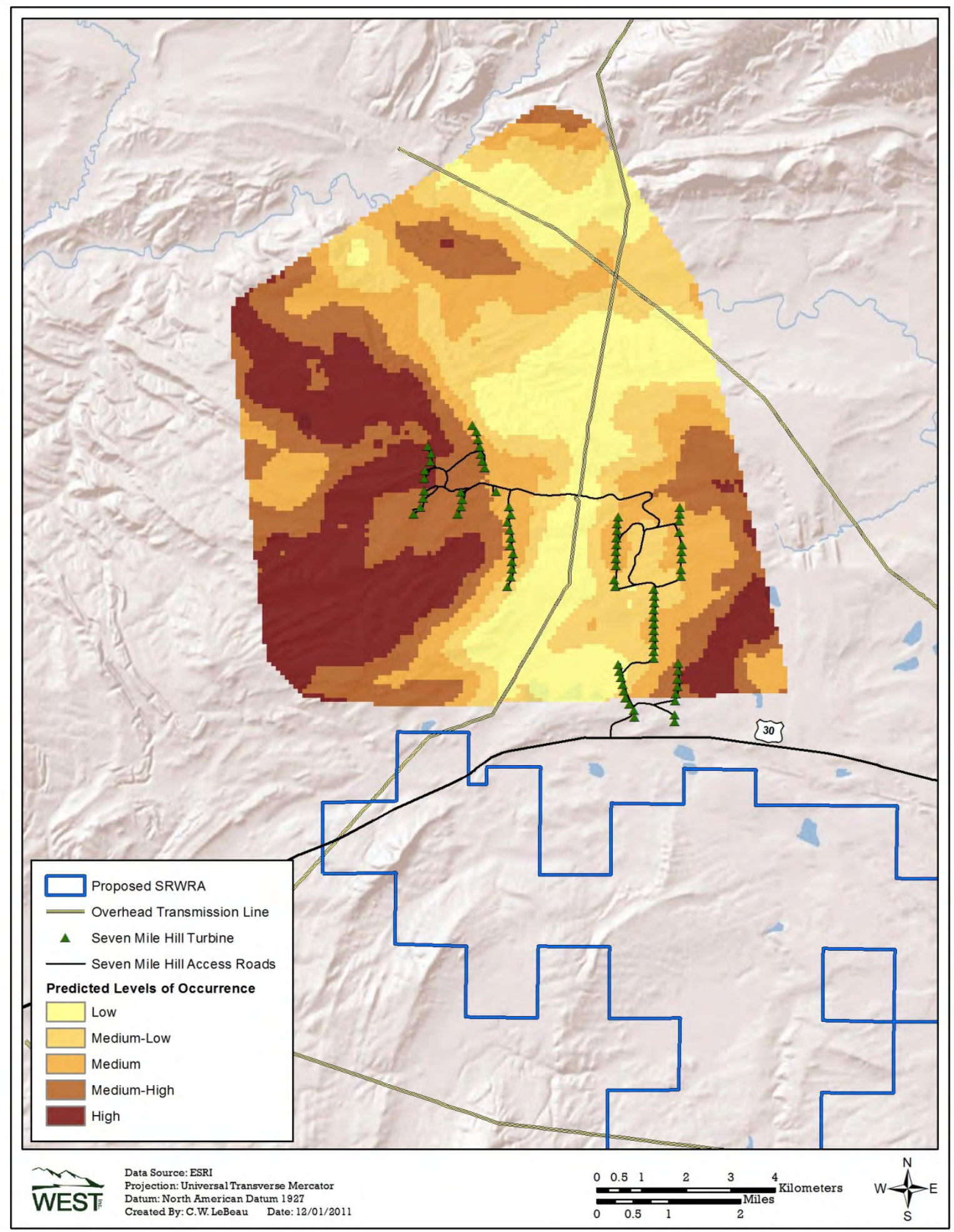

Figure 20. Predicted brood-rearing habitat used by sage-grouse within the Seven Mile Hill study area, Carbon County, Wyoming, 2009 and 2010. 


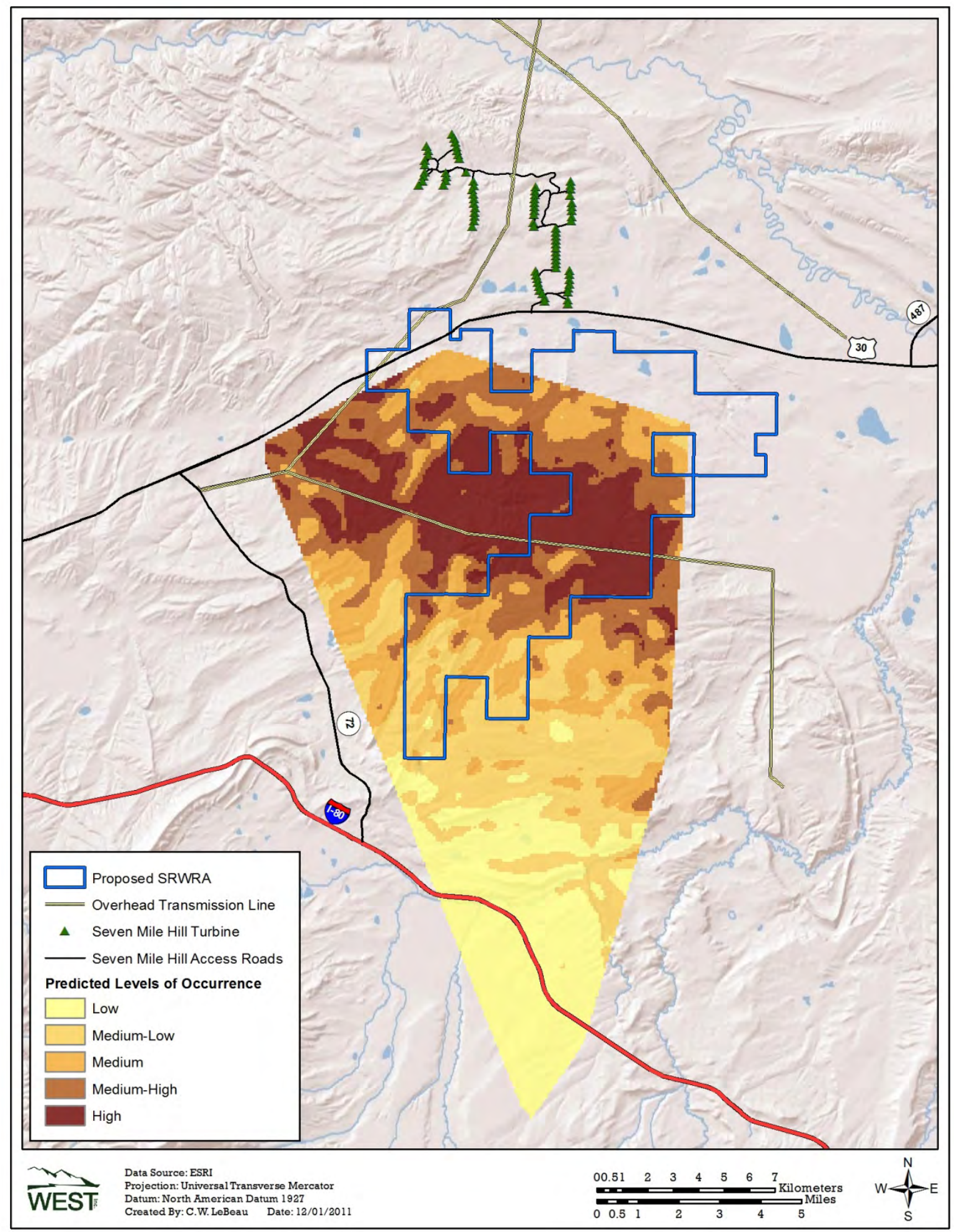

Figure 21. Predicted brood-rearing habitat used by sage-grouse within the Simpson Ridge study area, Carbon County, Wyoming, 2009 and 2010. 


\section{Summer Occurrence}

A total of 1,961 summer locations (SMH, $n=796$; SRWRA, $n=1,165)$ were recorded and included in the home range and habitat selection analysis. Home range sizes were larger within the SRWRA study area compared to the SMH study area; however, the proportion of utilization distributions within $1.6 \mathrm{~km}$ of the SMH turbines and the SRWRA project area were similar, with the $75 \%$ contours containing most of the project areas (Table 18; Figure 22).

Table 18. Estimated home range size $\left(\mathrm{km}^{2}\right)$ and estimated proportion within each project area for observed summer locations within both study areas in Carbon County, Wyoming.

\begin{tabular}{lrrrr}
\hline \hline & \multicolumn{2}{c}{ Seven Mile Hill } & \multicolumn{2}{c}{ Simpson Ridge } \\
Utilization Distribution & Total km & \% within SMH & Total km & \% within SRWRA \\
\hline $95 \%$ Kernel Contour & 132.4 & $30.1 \%$ & 222.7 & $39.8 \%$ \\
$90 \%$ Kernel Contour & 91.2 & $35.8 \%$ & 143.4 & $45.9 \%$ \\
$75 \%$ Kernel Contour & 38.2 & $43.0 \%$ & 64.7 & $55.3 \%$ \\
\hline \hline
\end{tabular}




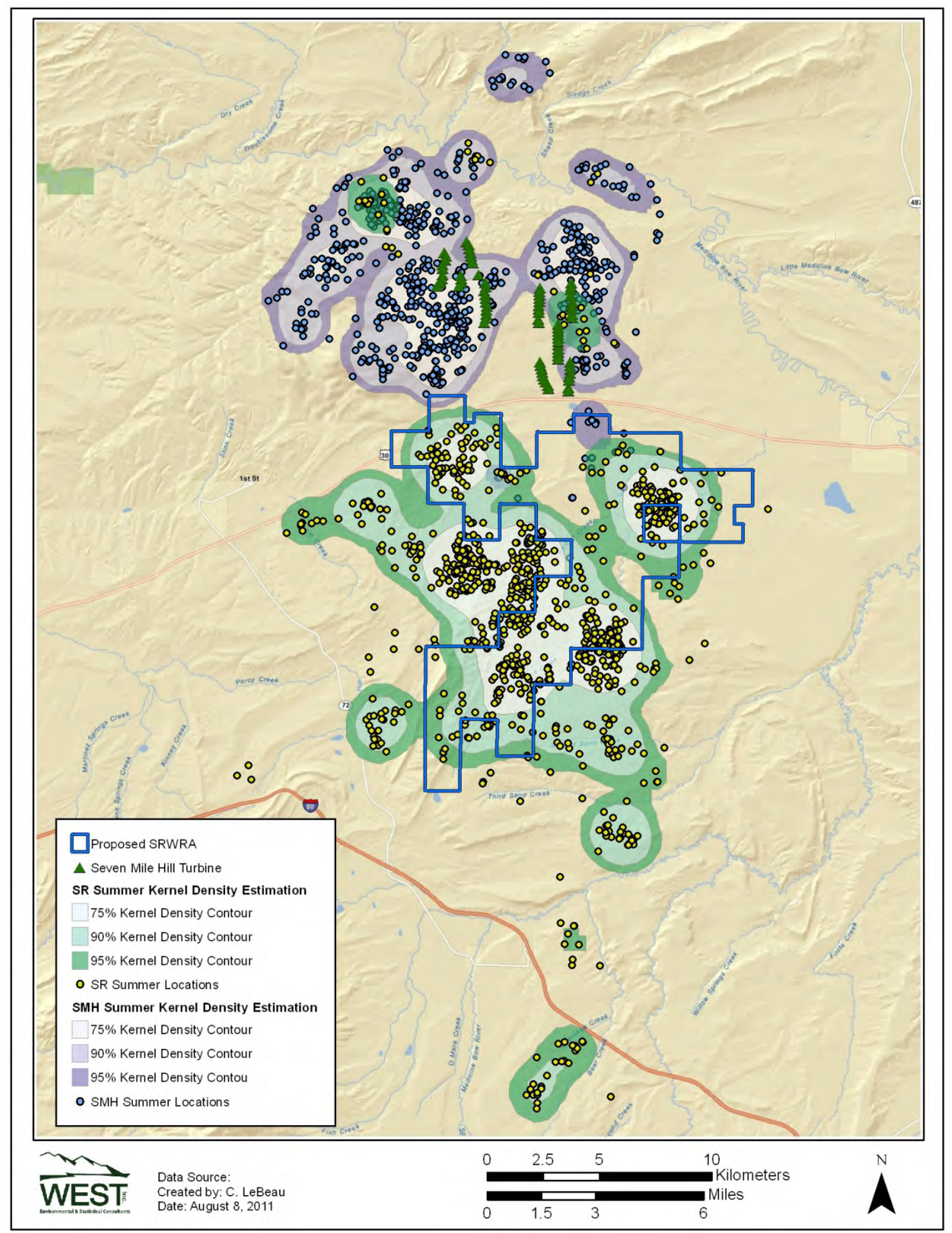

Figure 22. Utilization distributions of sage-grouse summer locations at the Simpson Ridge and Seven Mile Hill study areas, Carbon County, Wyoming, 2009-2010. 
MCPs were placed around all SRWRA and SMH summer locations to delineate each study area and the available summer habitat. The SRWRA MCP $\left(751.09 \mathrm{~km}^{2}\right)$ was 3-times the size of the $\mathrm{SMH}$ MCP $\left(242.89 \mathrm{~km}^{2}\right)$. A total of 3,985 available points were used within SMH and 5,845 were used within SRWRA.

The distance to major roads and to nearest occupied lek, and percent bare ground were included in the top model for both study areas. Distance to nearest turbine and elevation were additional covariates included in the SMH top model. Percent herbaceous cover and Wyoming big sagebrush cover also were included in the SRWRA top model. The next approximating model observed at both study areas was greater than approximately $40 \Delta \mathrm{AICc}$ points from the top model (Table 19).

Table 19. Model fit statistics for greater sage-grouse summer occurrence at the Seven Mile Hill and Simpson Ridge study areas, Carbon County, Wyoming, 2009 and 2010. Models are listed according to the model best fitting the data and ranked by $(\triangle A I C c)$, the difference between the model with the lowest Akaike's Information Criterion for small samples (AICc) and the AICc for the current model. The value of the maximized log-likelihood function $(\log [L])$, the number of estimated parameters (K), and Akaike's weights (wi) for each model are also presented.

\begin{tabular}{|c|c|c|c|c|c|}
\hline Model & $\mathrm{K}$ & AICc & $\triangle \mathrm{AICc}$ & $w_{i}$ & $\log [\mathrm{L}]$ \\
\hline \multicolumn{6}{|l|}{ Seven Mile Hill } \\
\hline $\begin{array}{l}\text { lek_dist, bare-ground300, dist_major_rds, dist_turbine, } \\
\text { elevation1000 }\end{array}$ & 7 & 3774.1 & 0.00 & 1.00 & -1880.39 \\
\hline lek_dist, bare-ground300, dist_major_rds, dist_turbine & 6 & 3841.0 & 66.9 & 0.00 & -1915.01 \\
\hline lek_dist, bare-ground300, dist_major_rds, & 5 & 3926.7 & 152.6 & 0.00 & -1959.02 \\
\hline lek_dist, bare-ground300 & 3 & 3973.4 & 199.3 & 0.00 & -1983.44 \\
\hline lek_dist & 2 & 4094.3 & 320.3 & 0.00 & -2045.04 \\
\hline \multicolumn{6}{|l|}{ Simpson Ridge } \\
\hline $\begin{array}{l}\text { lek_dist, bare-ground1000, dist_major_rds, } \\
\text { dist_major_rds }{ }^{2} \text {, herbaceous } 1000 \\
\text { Wyoming sagebrush } 1000\end{array}$ & 7 & 5266.1 & 0.00 & 1.00 & -2625.4 \\
\hline $\begin{array}{l}\text { lek_dist, bare-ground1000, dist_major_rds, } \\
\text { dist_major_rds }{ }^{2} \text {, herbaceous } 1000\end{array}$ & 6 & 5309.3 & 43.2 & 0.00 & -2648.2 \\
\hline $\begin{array}{l}\text { lek_dist, bare-ground1000, dist_major_rds, } \\
\text { dist_major_rds }\end{array}$ & 5 & 5388.6 & 122.6 & 0.00 & -2688.7 \\
\hline lek_dist, bare-ground1000 & 3 & 5567.2 & 301.1 & 0.00 & -2780.3 \\
\hline lek_dist & 2 & 5931.1 & 665.0 & 0.00 & -2963.4 \\
\hline
\end{tabular}

The estimated relative probability of selecting summer habitat within $\mathrm{SMH}$ decreased by approximately $27 \%$ for every 1 -unit increase in distance from nearest occupied lek and by $22 \%$ for every 1-unit increase in distance to nearest turbine $(90 \% \mathrm{Cl},-39$ to $-15 \%$ and -33 to $-10.7 \%$, respectively; Table 20, Figure 23). Summer habitat selection increased by $17 \%$ for every 1 -unit 
increase in distance from nearest major road $(90 \% \mathrm{Cl}, 7.3$ to 29\%; Table 20; Figure 23). In addition, summer habitat selection decreased by $7 \%$ for every 1-unit increase in percent bare ground cover within a $0.30 \mathrm{~km}$ radius buffer $(90 \% \mathrm{Cl},-9.4$ to -5.4 ; Table 20 , Figure 23). Lastly, summer habitat selection increased by $0.76 \%$ for every 1 -unit increase in elevation $(90 \% \mathrm{Cl}$, 0.27 to 1.33; Table 20, Figure 23)

Similar to $\mathrm{SMH}$, the relative probability of selecting summer habitat within SRWRA decreased by approximately $23 \%$ for every 1-unit increase in distance from nearest occupied lek and by $13 \%$ for every 1-unit increase in percent bare ground cover within a $1 \mathrm{~km}$ radius buffer $(90 \% \mathrm{Cl}$, -35 to -10 and -18 to $-8.0 \%$, respectively; Table 20, Figure 24). In addition, summer habitat selection increased as distance to nearest major road increased up to $8.68 \mathrm{~km}$, then declined (Figure 24). Lastly, summer habitat selection increased by $13 \%$ with every 1-unit decrease in percent herbaceous cover and increased by $34 \%$ with every 1-unit increase in Wyoming big sagebrush cover within a $1 \mathrm{~km}$ radius buffer $(90 \% \mathrm{Cl},-23$ to -4.0 and 7.3 to $78 \%$, respectively; Table 20; Figure 24).

Table 20. Selection ratios and slope coefficients for covariates in the sage-grouse top summer occurrence model for the Seven Mile Hill and Simpson Ridge study areas in Carbon County, Wyoming, USA, 2009 and 2010. Selection ratios measure the multiplicative change in relative probability of selection when a covariate changes by 1 unit, assuming all other covariates remain constant. Selection ratios were not calculated for covariates involved with a quadratic effect because they were dependent on values of other variables.

\begin{tabular}{|c|c|c|c|c|c|c|}
\hline \multirow{2}{*}{ Description } & \multirow{2}{*}{ Coefficient } & \multicolumn{2}{|c|}{ 90\% Confidence Interval } & \multirow{2}{*}{$\begin{array}{l}\text { Selection } \\
\text { Ratio }\end{array}$} & \multicolumn{2}{|c|}{ 90\% Confidence Interval } \\
\hline & & Lower & Upper & & Lower & Upper \\
\hline \multicolumn{7}{|l|}{ Seven Mile Hill } \\
\hline (Intercept) & -11.88 & & & & & \\
\hline lek_dist & -0.31 & -0.49 & -0.16 & -26.5 & -38.7 & -15.0 \\
\hline bare-ground 300 & -0.08 & -0.10 & -0.06 & -7.33 & -9.44 & -5.44 \\
\hline dist_major_rds & 0.16 & 0.07 & 0.26 & 17.1 & 7.29 & 29.0 \\
\hline dist_turbine & -0.25 & -0.41 & -0.11 & -22.4 & -33.3 & -10.7 \\
\hline elevation1000 & 0.01 & 0.00 & 0.01 & 0.76 & 0.27 & 1.33 \\
\hline \multicolumn{7}{|l|}{ Simpson Ridge } \\
\hline (Intercept) & 5.63 & & & & & \\
\hline lek_dist & -0.25 & -0.43 & -0.11 & -22.5 & -35.3 & -10.4 \\
\hline bare-ground 1000 & -0.14 & -0.19 & -0.08 & -12.9 & -17.6 & -7.98 \\
\hline dist_major_rds & 0.40 & NA & NA & NA & NA & NA \\
\hline dist_major_rds ${ }^{2}$ & -0.02 & -0.05 & 0.00 & NA & NA & NA \\
\hline herbaceous 1000 & -0.14 & -0.26 & -0.04 & -13.4 & -23.1 & -3.96 \\
\hline wygenis1000 & 0.29 & 0.07 & 0.58 & 34.2 & 7.28 & 78.4 \\
\hline
\end{tabular}




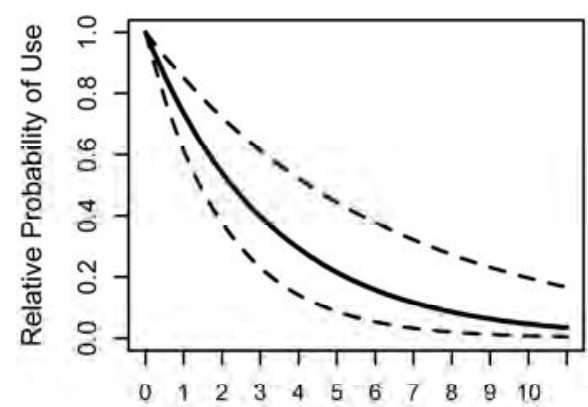

Distance to Nearest Occupied Lek $(\mathrm{km})$

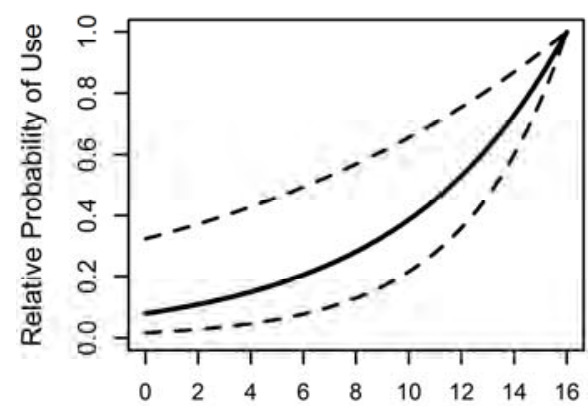

Distance to Nearest Major Road ( $\mathrm{km})$

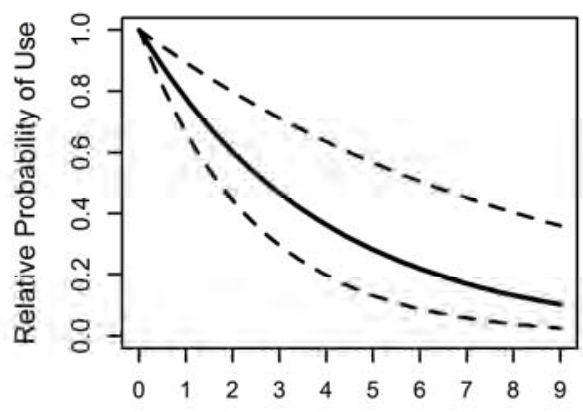

Distance to Nearest Turbine $(\mathrm{km})$

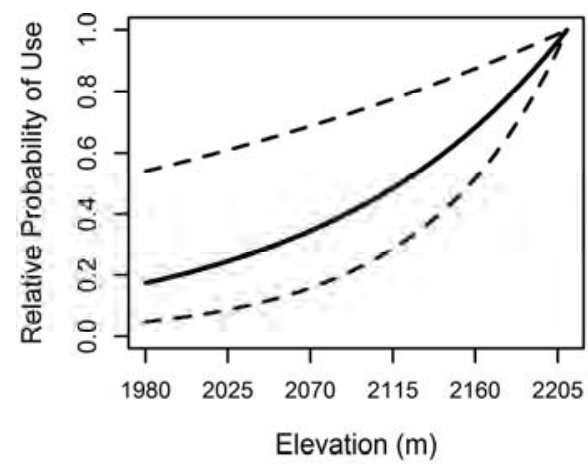

Figure 23. Relative probability of female sage-grouse summer occurrence and $90 \%$ $\mathrm{Cl}$ within the Seven Mile Hill study area as a function of top model covariates, Carbon County, Wyoming, 2009 and 2010. Variables that are not plotted were held constant at their median value. 

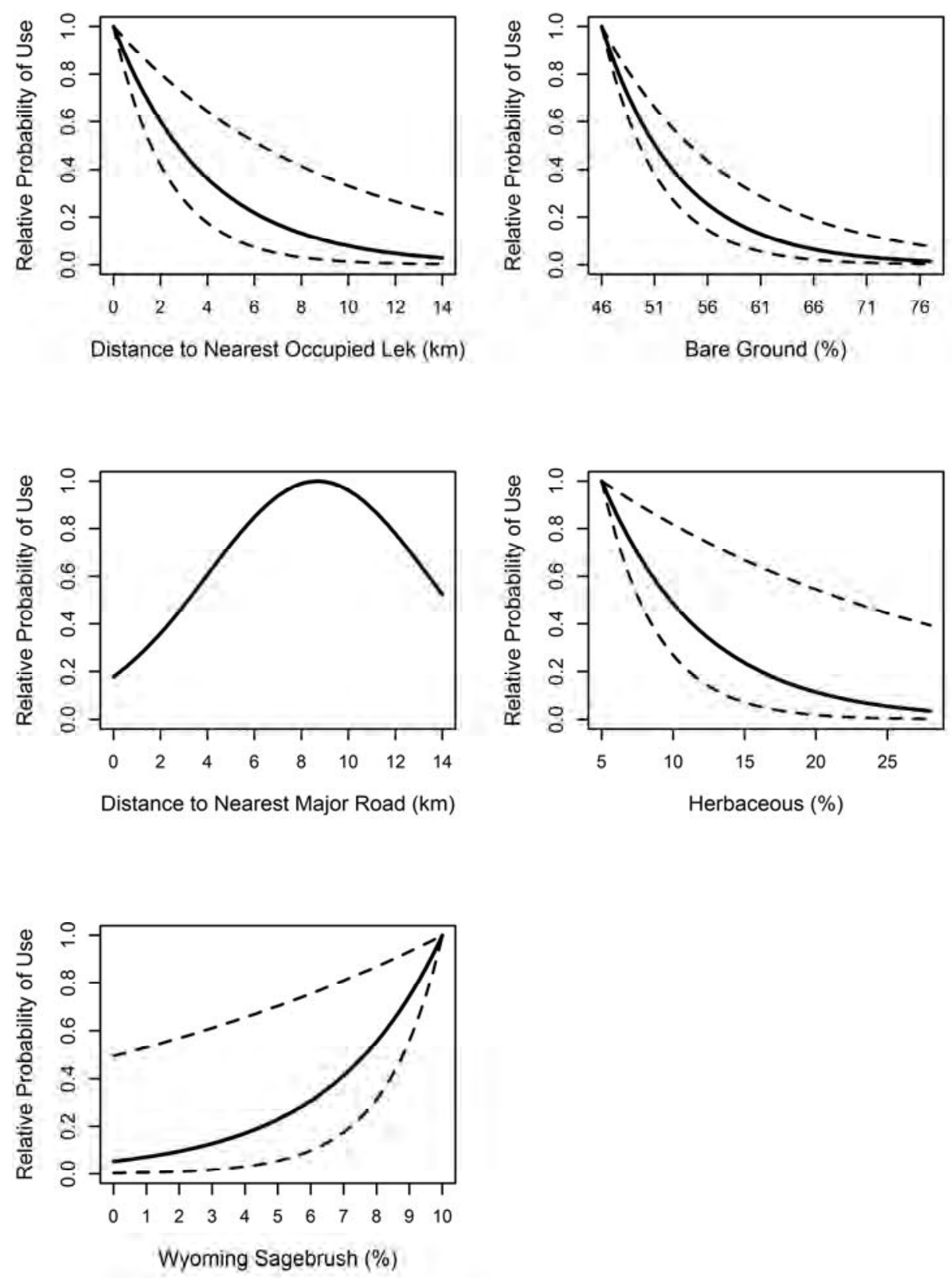

Figure 24. Relative probability of female sage-grouse occurrence and $90 \% \mathrm{Cl}$ within the Simpson Ridge study area as a function of top model covariates, Carbon County, Wyoming, 2009 and 2010. Variables that are not plotted were held constant at their median value 
Similar to the home range analysis, the proportion of predictive bins within $1.6 \mathrm{~km}$ of SMH turbines and within the SRWRA project area were determined to identify high probability of use areas within each project. RSF values were equally divided into 5 quantile predictive bins ranging from low to high predictive use. The proportion of high use areas was relatively high within SMH (40.5\%; Table 21, Figure 25). Approximately thirty percent of high use areas occurred within the SRWRA project area (Table 21, Figure 26).

Table 21. The proportion of summer occurrence predictive bin values within $1.6 \mathrm{~km}$ of Seven Mile Hill turbines and within the Simpson Ridge project area.

\begin{tabular}{lrr}
\hline \hline Predictive Bin (RSF values) & Proportion within SMH & Proportion within SRWRA \\
\hline Low & $1.7 \%$ & $3.4 \%$ \\
Medium - Low & $14.2 \%$ & $7.6 \%$ \\
Medium & $23.2 \%$ & $14.4 \%$ \\
Medium-High & $37.9 \%$ & $19.7 \%$ \\
High & $40.5 \%$ & $29.8 \%$ \\
\hline \hline
\end{tabular}




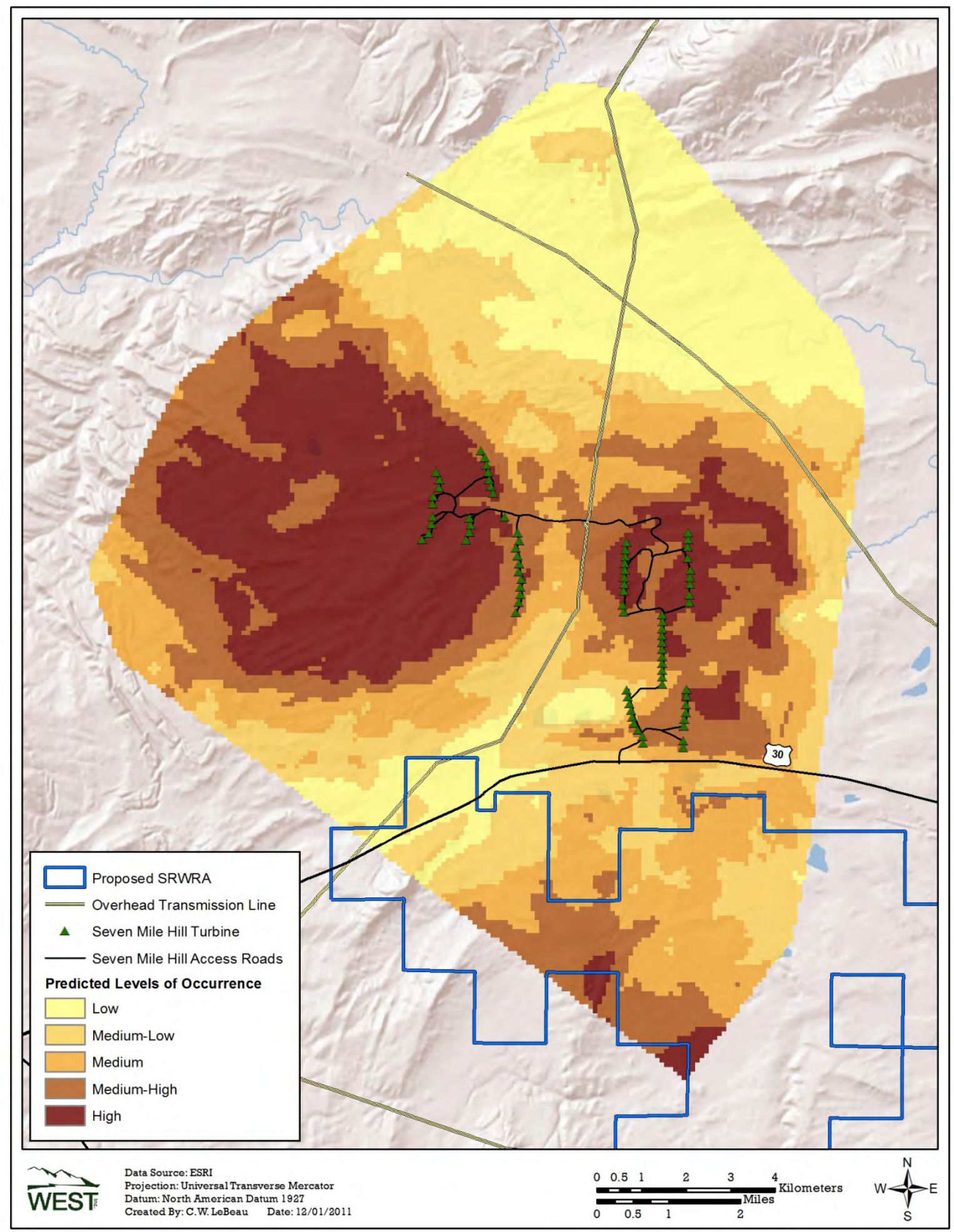

Figure 25. Predicted summer habitat used by female sage-grouse within the Seven Mile Hill study area, Carbon County, Wyoming, 2009 and 2010. 


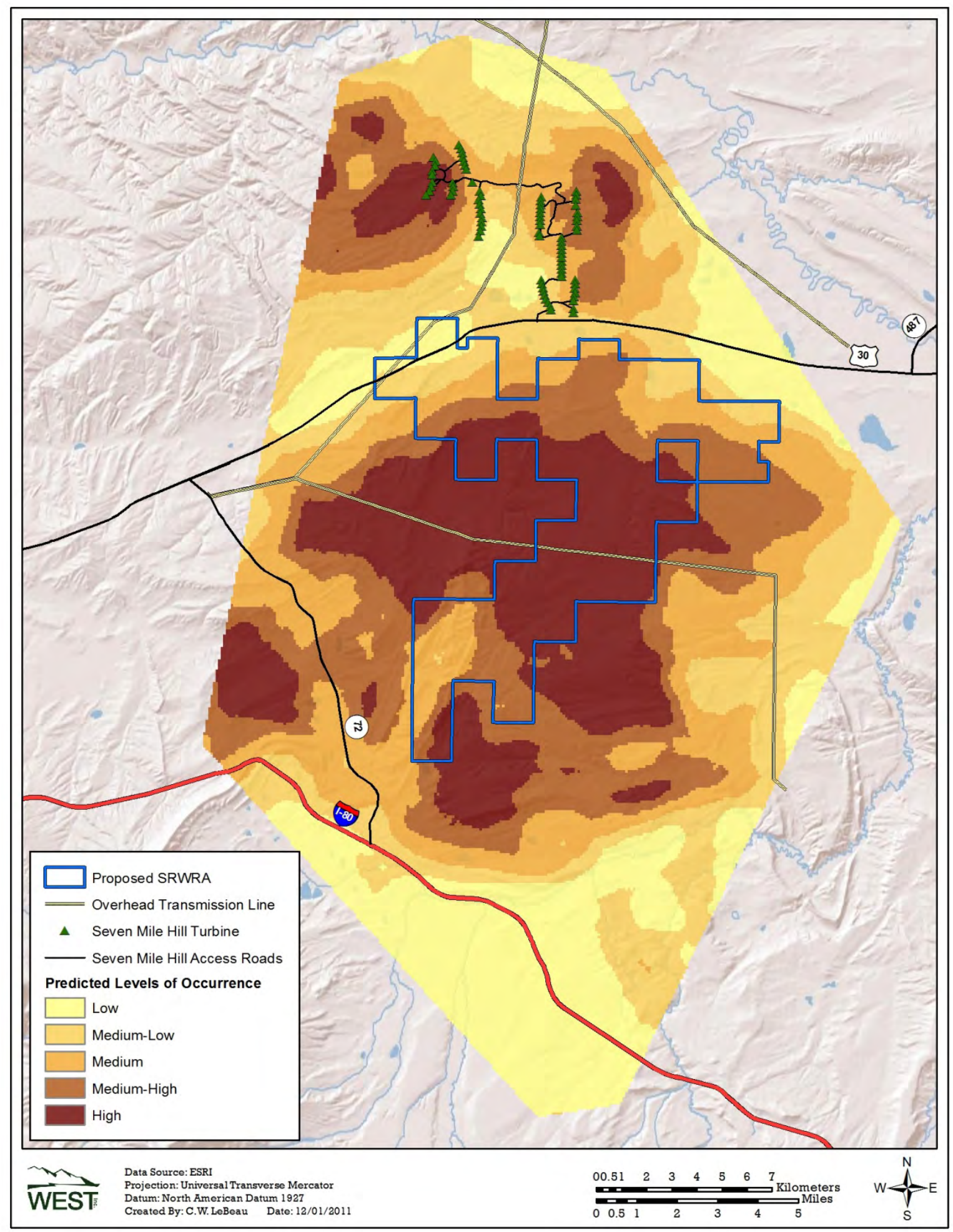

Figure 26. Predicted summer habitat used by female sage-grouse within the Simpson Ridge study area, Carbon County, Wyoming, 2009 and 2010. 


\section{Fall and Winter Distribution}

Collared female sage-grouse were monitored every other week during the fall period (September through November) at both study areas, while we recorded monthly locations via aerial telemetry during the winter period (December through March). Similar to the summer season, we delineated home ranges for the fall and winter seasons; however, we did not develop predictive maps for these seasons due the infrequent monitoring schedule. A total of 397 fall locations (SMH, $n=157$; SRWRA, $n=240$ ) were included in the fall home range analysis and 321 winter locations (SMH, $n=132$; SRWRA, $n=189)$ were included in the winter home range analysis. Home range sizes were larger within the SRWRA study area compared to the SMH study area for both seasons; however, the proportion of utilization distributions within $1.6 \mathrm{~km}$ of the SMH turbines and the SRWRA project area were similar, with the $75 \%$ contours containing most of the project areas (Table 22, Figure 27, Figure 28).

Table 22. Estimated home range size $\left(\mathrm{km}^{2}\right)$ and estimated proportion within each project area for observed fall and winter locations within both study areas in Carbon County, Wyoming, 2009-2010.

\begin{tabular}{|c|c|c|c|c|}
\hline \multirow[b]{2}{*}{ Utilization Distribution } & \multicolumn{2}{|c|}{ Seven Mile Hill } & \multicolumn{2}{|c|}{ Simpson Ridge } \\
\hline & Total km² & $\%$ within $\mathrm{SMH}$ & Total $\mathrm{km}^{2}$ & \% within SRWRA \\
\hline \multicolumn{5}{|c|}{ Fall } \\
\hline 95\% Kernel Contour & 273.3 & $19.8 \%$ & 322.6 & $31.2 \%$ \\
\hline $90 \%$ Kernel Contour & 212.7 & $23.8 \%$ & 226.3 & $37.7 \%$ \\
\hline $75 \%$ Kernel Contour & 111.0 & $33.9 \%$ & 111.3 & $53.7 \%$ \\
\hline \multicolumn{5}{|c|}{ Winter } \\
\hline 95\% Kernel Contour & 411.3 & $13.9 \%$ & 269.2 & $28.4 \%$ \\
\hline $90 \%$ Kernel Contour & 282.4 & $19.6 \%$ & 209.6 & $32.4 \%$ \\
\hline $75 \%$ Kernel Contour & 128.8 & $32.6 \%$ & 98.7 & $49.1 \%$ \\
\hline
\end{tabular}




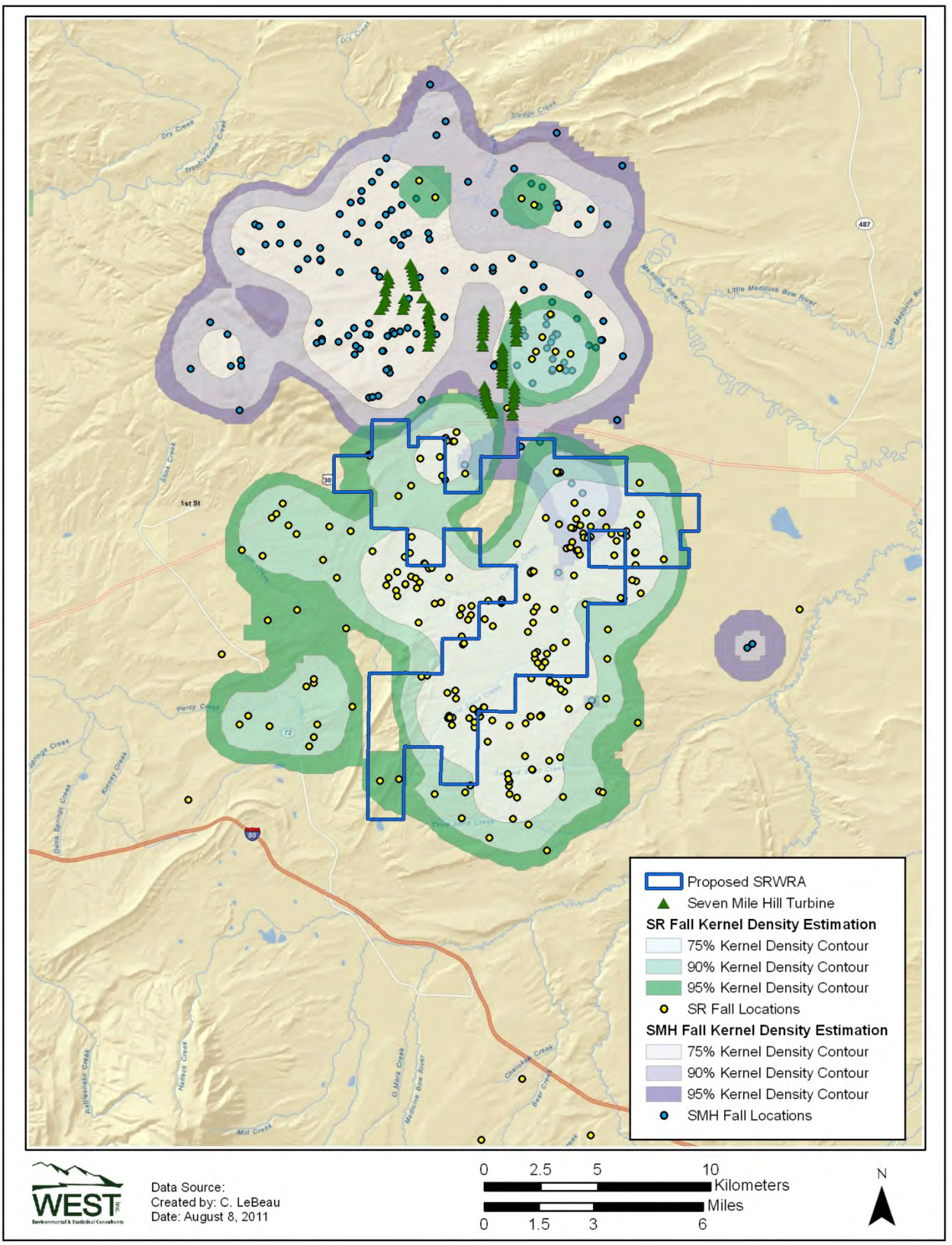

Figure 27. Utilization distributions of sage-grouse fall locations at the Simpson Ridge and Seven Mile Hill study areas, Carbon County, Wyoming, 2009-2010. 


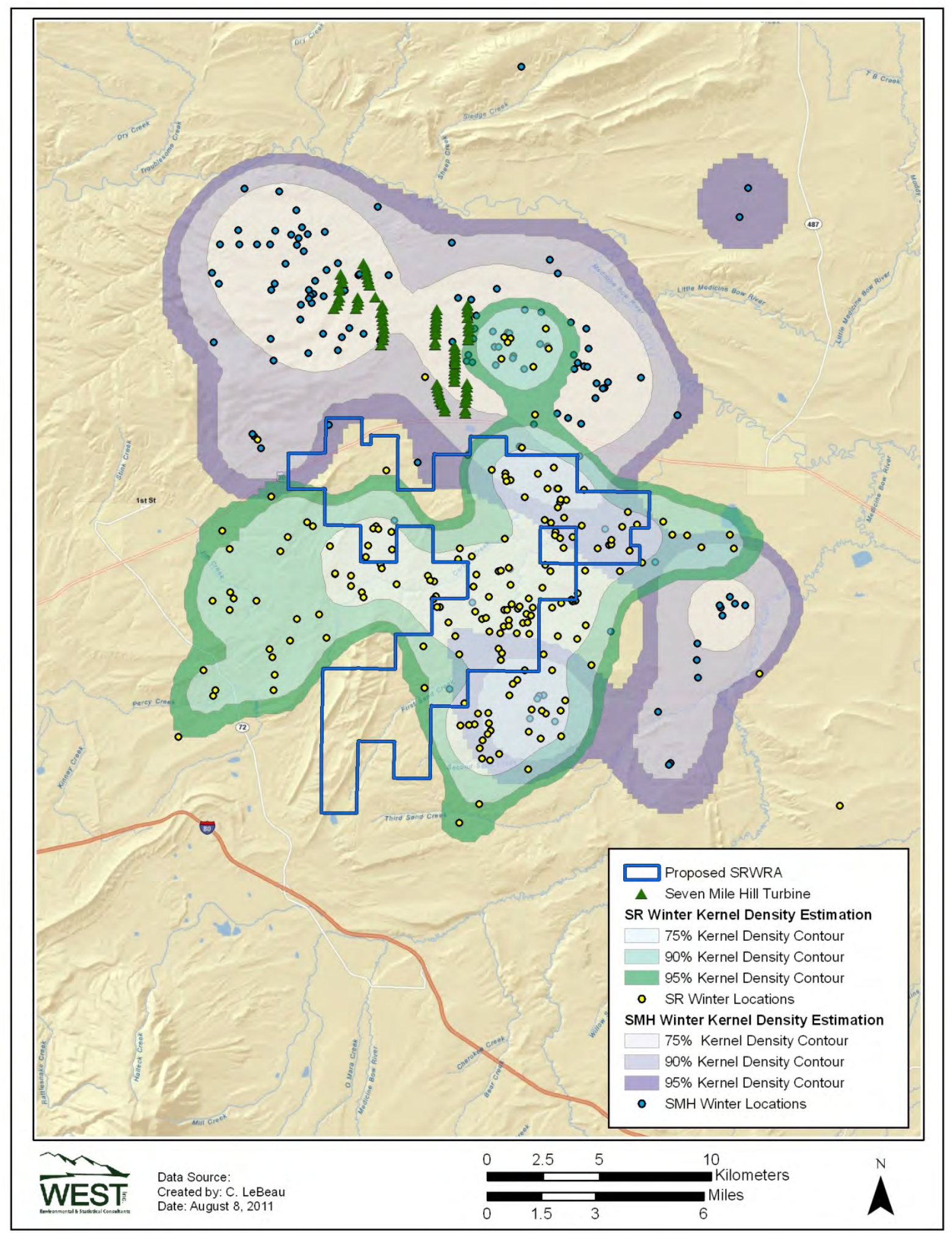

Figure 28. Utilization distributions of sage-grouse winter locations at the Simpson Ridge and Seven Mile Hill study areas, Carbon County, Wyoming, 2009-2010. 


\section{DISCUSSION}

\section{Greater Sage-Grouse Lek Counts}

Trends in greater sage-grouse population abundance are typically indexed through lek counts (Beck and Braun 1980, Connelly and Braun 1997, Walsh et al. 2004). While the use of telemetry is the best method to determine population demographic rates, lek counts provide a good index of breeding population levels and in many cases long-term data sets are available for trend analysis (Connelly et al. 2000a, Connelly and Braun 1997). Lek counts have been used to provide information on sage-grouse breeding populations in response to disturbances including prescribed burning (Connelly et al. 2000b) and oil and gas development (Holloran 2005, Walker et al. 2007, Harju et al. 2010, Holloran et al. 2010).

The use of telemetry to investigate population demographics within both study areas did not occur until after the Seven Mile Hill Wind Energy Facility was operational. However, lek counts were conducted within both study areas prior to construction of the wind energy facility. These pre-development lek counts provide an index to the sage-grouse population status prior to the construction of the Seven Mile Hill Wind Energy Facility.

Population trends within the study area as estimated from lek counts generally tracked trends witnessed throughout Wyoming in 2009 and 2010, where lek counts tended to be lower than they were in 2008. The peak male sage-grouse count for the three project area leks with survey data one year prior to and two years following construction (see Table 2, Figure 3) was 130 in 2008, the spring immediately prior to construction, 103 in 2009 and 70 in 2010, the first and second breeding seasons after construction. However, in the SRWRA, the combined maximum male count on nine leks monitored annually since 2008 dropped from 333 in 2008 to 204 in 2010. A similar downward trend in 2010 lek count data was noted for the region as a whole (Will Shultz, WGFD, personal communication).

\section{Nest Success}

Nest success is an important vital rate of sage-grouse populations and can be used to assess trends in population productivity. Nest success is defined as the probability of a nest to hatch one or more eggs successfully (Rotella et al. 2004). Poor nest success has often been related to sage-grouse population declines (Crawford and Lutz 1985, Gregg et al. 1994, Schroeder 1999). The average nest success rate for sage-grouse reported in 29 studies using radiotelemetry was $46 \%$ (range: $15-86 \%$ ), and was widely dependent on region, habitat conditions, and study design (Connelly et al. 2011). Nest success also differs from unaltered habitats (61\% of studies reported $\geq 50 \%$ and $22 \%$ of studies reported $<40 \%$ overall nest success) to altered habitats $(17 \%$ of studies reported $\geq 50 \%$ and $42 \%$ of studies reported $<40 \%$ overall nest success; Connelly et al. 2011).

Nest success within SMH (33\%) was similar to other sage-grouse studies that reported nest success in altered habitats which include other forms of energy development (<40\%; Connelly et al. 2011). Nest success at SRWRA (42\%) was slightly higher than at SMH (33\%) but not as 
high as the majority of studies in unaltered habitats ( $61 \%$ of studies reported $\geq 50 \%$; Connelly et al. 2011).

We investigated the relationship of nest success relative to wind energy infrastructure for all nests located within both study areas. The mean distance of successful nests relative to infrastructure features was not statistically different from the mean distance of failed nests. In addition, the proximity of anthropogenic features did not accurately predict sage-grouse nest success within both study areas. The age of female sage-grouse (adult and juvenile) was included as a single predictor in the top model; however, the next approximating model was the null model, differing by 0.76 AICc points, suggesting the covariates used in the analysis did not accurately predict nest success relative to the features on the landscape. Similarly, Holloran and Anderson (2005) experienced high model uncertainty when predicting sage-grouse nest success within Wyoming. Further investigation of fine scale habitat features associated with each sage-grouse nest located within the study area may predict nest success more accurately (Kolada et al. 2009).

\section{Brood-Rearing Success}

In addition to nesting success, early and late brood success is a key parameter in assessing sage-grouse population demographics because juvenile survival impacts overall population productivity (Crawford et al. 2004 and Connelly et al. 2011). Beck et al. (2006) provided estimates that indicate juvenile survival equals adult survival after 10 weeks of age, suggesting that nesting and early brood-rearing success are critical drivers of population change. We defined early brood-rearing success as the proportion of broods that survived 14 days posthatch (Thompson et al. 2006) and late brood success as the proportion of broods that survived 35 days post-hatch (Walker 2008).

Typical sage-grouse chick survival during the early brood period (18 days post hatch) was estimated to be 44\% (Rebholz 2007) and typical chick survival during the late brood period (35 days post hatch) was estimated to be 33-50\% (Walker 2008). Early brood-rearing success was relatively high within both the SRWRA and SMH study areas and much higher compared to other studies (Rebholz 2007). This could be due to use of different methods for detecting the presence of chicks. However, late brood-rearing success showed similar trends of being higher than other studies. Aldridge and Boyce (2007) reported that chick mortality was 1.5-times higher in habitats where oil and gas wells were visible. Although late brooding-rearing success was lower within areas of wind energy development $(\mathrm{SMH} ; 9 \pm 7.2 \%)$ compared to SRWRA (14 \pm $7.2 \%)$, the differences were not statistically different.

\section{Female Survival}

Estimating adult female survival is useful in understanding animal population trends because it compares the cumulative effects of environmental conditions or anthropogenic influences to the overall persistence of the population or the growth rate $(\lambda)$. Sage-grouse declines are at least partially explained by lower annual survival of female sage-grouse, and in the case of oil and gas development, the impacts to survival result in population-level declines (Holloran 2005). Sage-grouse are characterized as having high annual survival compared to other upland game 
birds. Annual survival rate of adult female sage-grouse in Wyoming is estimated to be $48-78 \%$ (Holloran 1999, 2005). Female survival within both study areas was similar to the estimated range within Wyoming (67\% at SRWRA and 69\% at SMH). Seasonal survival is variable for both male and female sage-grouse, but is highest during the winter (88-100\%; Beck et al 2006). Similar to other study areas, survival at SMH and SRWRA was highest during the winter period and lowest during the spring season. Survival was similar among study areas, suggesting no decrease in female survival at SMH. Further investigation into predicting variable levels of risk within altered and unaltered habitats may provide additional insight into the impacts of wind energy development and survival.

\section{Greater Sage-grouse Female Occurrence}

The sage-grouse populations within both study areas are relatively non-migratory (Connelly et al. 2000a), as radio-marked sage-grouse used similar areas during all annual life cycles. We developed resource selection functions to investigate the relationship of wind energy infrastructure on sage-grouse nesting, brood-rearing, and summer habitat occurrence. We hypothesized that female sage-grouse selected nest sites, brood-rearing and summer habitat further away from wind energy infrastructure than expected.

Few similarities existed between the top models of nest site selection within SMH and SRWRA. Percent shrub cover was an important predictor within $\mathrm{SMH}$, and shrub height was important within the SRWRA study area. Shrub components have also been an important predictor for sage-grouse nest site selection in other studies (Holloran et al. 2005, Hagen et al. 2007, Doherty et al. 2010). Sage-grouse selecting nesting sites within SMH seem to be uninfluenced by the presence of turbines. Distance to nearest turbines was not included in the top SMH model for nest site selection, and when added to the top model, it did not improve model fit (i.e., slope coefficients were not significant at the $95 \%$ level and AICc scores did not improve). Sagegrouse selected for nest sites closer to leks and avoided major roads within SMH compared to SRWRA where they selected for habitats closer to transmission lines. Based on an extensive literature review of greater sage-grouse response to power lines (Johnson 2009) observed or measured responses to transmission lines vary greatly. Impacts range from no apparent or low impacts to one study in California that concluded population impacts may occur out to 3 miles from transmission lines, and impacts to leks have been noted out to 5 miles from transmission lines. Impacts may be related to avoidance of raptors and nest predators (e.g., common ravens [Corvus corax]) that use these lines for nesting and perching, or avoidance of tall structures (Johnson 2009). Based on our data, sage-grouse selected habitats closer to the transmission line within SRWRA. The transmission line at SRWRA has existed for over 10 years and the quality of the habitat surrounding the transmission line may outweigh the potential risk to sagegrouse from perching raptors species.

Similar to nest site occurrence, the top models for brood-rearing occurrence differed between SMH and SRWRA. Specifically, sage-grouse within SMH selected brood-rearing habitats further from transmission lines. The habitat surrounding transmission lines located within the $\mathrm{SMH}$ study area was coincidentally comprised of greater percent bare ground and subsequently less shrub cover, which is not characteristic of sage-grouse brood-rearing habitats (Aldridge and 
Boyce 2007, Connelly et al. 2000a). Distance to nearest transmission line was included in the top brood-rearing model for SR; however there was substantial variability across individual birds. Similarly, herbaceous cover was included within both the SR and SMH top models but herbaceous cover within SR had high variability at predicting the relative probability of occurrence. The selection pattern within $\mathrm{SMH}$ is consistent with other studies of sage-grouse, where brooding areas consistently have higher grass or herbaceous cover (Hagen et al. 2007, Holloran 1999). However, brooding sage-grouse in both study areas avoided habitats with a higher percentage of bare ground and selected for habitats that had a higher percentage of shrub (SMH) and litter cover (SRWRA). In southeastern Alberta (Aldridge and Boyce 2007) and south-central Wyoming (Kirol et al. 2012), broods selected habitats with greater sagebrush cover, which was consistent with brood habitat selection in both the SRWRA and SMH study areas. Distance to nearest turbines was not included in the SMH top model for brood-rearing occurrence, and when added to the top model, distance to nearest turbine did not improve model fit (i.e., slope coefficients were not significant at the $95 \%$ level and $\mathrm{AIC}_{\mathrm{c}}$ scores did not improve).

Unlike the SRWRA and SMH nest and brood-rearing occurrence models, similarities existed among the top covariates included in the SMH and SRWRA female summer occurrence models. Probability of female habitat selection in summer increased as distance to nearest lek decreased, percent bare ground decreased, and as distance to nearest major road increased within both study areas. Distance to nearest turbine was included in the top SMH summer occurrence model, but its affect on the relative probability of selection was different from what was hypothesized, as sage-grouse in the SMH study area appeared to be selecting for habitats closer to turbines. Distance to turbine was not correlated with any habitat features that existed on the landscape; however, distance to nearest lek and percent bare-ground accurately predicted distance to nearest turbine. As distance from the nearest turbine increased, the distance to nearest lek also increased ( $\beta=0.47, P \leq 0.001$ ) suggesting lower probability of selection further from leks and subsequently further from turbines. Similarly, sage-grouse avoided areas with a higher percentage of bare ground and percent bare ground accurately predicted distance to nearest turbine $(\beta=0.02 P \leq 0.001)$. As percent bare ground increased, the distance from nearest turbine also increased, suggesting lower probability of selection further from turbines as a result of an increase in percent bare ground. Ultimately, the relative probability of selection increased as distance to nearest lek and percent bare ground decreased, resulting in an increase in relative probability of selection within habitats that were closer to turbines.

The proportion of habitat with high probability of use ranged from $26 \%$ (nest occurrence) to $40.5 \%$ (summer occurrence) within $1.6 \mathrm{~km}$ of SMH turbines. Similarly, the proportion of habitat with high probability of use ranged from $29.8 \%$ (summer occurrence) to $39 \%$ (brood-rearing occurrence) within the SRWRA project area. The proportion of habitat with low predictive use within each season ranged from $0.1 \%$ (nest occurrence) to $3.4 \%$ (summer occurrence) within the SRWRA, suggesting greater abundance of high probability of use habitats within the SRWRA compared to low probability of use habitats. The proportion of habitat with low probability of use within $1.6 \mathrm{~km}$ of turbines ranged from $1.7 \%$ (summer occurrence) to $39.6 \%$ 
(brood-rearing), suggesting variable degrees of habitat use within $1.6 \mathrm{~km}$ of turbines (i.e., high summer and low brood rearing habitat use).

\section{Effects of Wind Energy on Grouse}

Much debate has occurred recently regarding the potential impacts of wind-energy facilities on prairie grouse, including greater sage-grouse (Johnson and Stephens 2011). It is currently unknown how greater sage-grouse, which are accustomed to a relatively low vegetation canopy, would respond to numerous wind turbines hundreds of feet taller than the surrounding landscape. Some scientists speculate that such a skyline may displace greater sage-grouse hundreds of meters or even kilometers from their normal range (Manes et al. 2002, NWCC 2004, USFWS 2003). If birds are displaced, it is unknown whether, in time, local populations may become acclimated to elevated structures and return to the area. The USFWS (2003, 2004) argued that because prairie grouse evolved in habitats with little vertical structure, placement of tall man-made structures, such as wind turbines, in occupied prairie grouse habitat may result in a decrease in habitat suitability.

Several studies have shown that prairie grouse avoid other anthropogenic features, such as roads, power lines, oil and gas wells, and buildings (Robel et al. 2004; Holloran 2005; Pruett et al. 2009a, 2009b). Much of the infrastructure associated with wind energy facilities, such as power lines and roads, is common to most forms of energy development, and it is assumed that impacts would be similar. Nevertheless, there are substantial differences between wind energy facilities and most other forms of energy development, particularly related to human activity. Although results of these studies suggest that the potential exists for wind turbines to displace prairie grouse from occupied habitat, well-designed studies examining the potential impacts of wind turbines on greater sage-grouse grouse as well as other prairie grouse are lacking (Johnson and Holloran 2010). Ongoing telemetry research being conducted by Kansas State University to examine response of greater prairie chickens to wind energy development in Kansas and results of this study, as well as similar studies being initiated at the proposed Chokecherry/Sierra Madre wind energy project in Wyoming and the China Mountain wind energy project in Idaho, will help to address this knowledge gap.

Other than these ongoing telemetry studies, we are aware of only three publicly available studies that examined response of prairie grouse species to wind energy development. The Nebraska Game and Parks Commission (NGPC) monitored both greater prairie-chicken and sharp-tailed grouse leks following construction of the 36-turbine Ainsworth wind-energy facility in Brown County, Nebraska (NGPC 2009). Surveys for leks were conducted four years postconstruction (2006-2009) within a 1.6 to $3.2 \mathrm{~km}$ radius of the facility, an area that covered approximately $65 \mathrm{~km}^{2}$. The number of leks of both species combined in the study area was 13 , 12,9 and 12 in the first four years post-construction. The number of greater prairie chickens counted on leks increased from 70 to 95 during the 4-year period, whereas the number of sharp-tailed grouse decreased from 66 to 56 . For both species combined, the numbers of birds on leks increased from 136 to 151 over the four year post-construction period. No preconstruction data were available on prairie grouse leks near the site; however, densities of lekking grouse on the study area at the Ainsworth facility were within the range of expected 
grouse densities in similar habitats in Brown County and the adjacent Rock County (NGPC 2009). The leks ranged from 0.7 to $2.7 \mathrm{~km}$ from the nearest turbine, with an average distance of $1.4 \mathrm{~km}$.

At a three-turbine wind energy facility in Minnesota, six active greater prairie-chicken leks were located within $3.2 \mathrm{~km}$ of turbines, with the nearest lek located within $1 \mathrm{~km}$ of the nearest turbine (USFWS 2004). During subsequent research at this facility based on 40 nest locations, it was found that nesting hens were not avoiding turbines. Based on extensive research of the prairie chicken population in the vicinity of this wind energy facility from 1997 to 2009, it was concluded that the distribution and location of leks and especially nests was determined by the presence of adequate habitat in the form of residual grass cover, not the presence of vertical structures such as trees, woodlots, power lines and wind turbines (Toepfer and Vodehnal 2009).

Greater prairie chicken lek surveys were conducted at the Elk River wind energy facility in Butler County, Kansas, within the southern Flint Hills, beginning three years prior to and continuing five years post-construction (Johnson et al. 2009). The facility consists of 100, 1.5-MW turbines. During the year immediately preceding construction of the project (2005), 10 leks were present on the project area, with 103 birds on all leks combined. By 2009, four years after construction, only one of these 10 leks remained active, with three birds on the lek. The 10 leks were located between $88 \mathrm{~m}$ and 1,470 $\mathrm{m}$ from the nearest turbine, with a mean distance of $587 \mathrm{~m}$; eight of the ten leks were located within $0.8 \mathrm{~km}$ of the nearest turbine. During the same time frame that leks were monitored at the Elk River facility, the estimated average number of greater prairie chickens in the southern Flint Hills declined by 65 percent from 2003 to 2009. In Butler County, the estimated number of birds declined by 67 percent from 2003 to 2009. This regional decline is attributed primarily to the practice of annual spring burning and heavy cattle stocking rates, which remove nesting and brood-rearing cover for prairie chickens (Robbins et al. 2002). Data collected since 2009 indicate prairie chicken use of the site has increased (Johnson and Young 2011). In 2010, none of the 10 leks previously identified on the site were active. However, two new active lek locations were documented, with one lek containing 13 birds present $0.82 \mathrm{~km}$ from the nearest turbine, and another lek containing 15 birds present $1.9 \mathrm{~km}$ from the nearest turbine. Based on lek counts conducted in the spring of 2011, eight active leks were present within $2.4 \mathrm{~km}$ of the facility, with a maximum total count of 130 greater prairie chickens on these leks, which is higher than the number of birds counted on leks one year prior to construction (103). The nearest lek was located approximately $200 \mathrm{~m}$ from the nearest turbine, six years after construction. According to the authors, the increase in leks in 2010 and especially 2011 coincided with reduced burning of rangeland at this site, providing further evidence that ranch management practices at this site also may have influenced prairie chicken use of the project area.

Outside of North America, we are aware of one other study of grouse response to wind turbines. The black grouse (Lyrurus tetrix), another grouse with a lek mating system, was found to be negatively affected by wind power development in Austria (Zeiler and Grünschachner-Berger 2009). The number of displaying males in the wind power development area increased from 23 to 41 during the 3-year period immediately prior to construction, but then declined to nine males 
four years after construction. In addition to the decline in displaying males, the remaining birds shifted their distribution away from the turbines. One lek located within $200 \mathrm{~m}$ of the nearest turbine declined from 12 birds one year prior to construction to no birds four years after construction.

\section{CONCLUSIONS}

The impacts to sage-grouse populations from wind energy infrastructure are not well understood. The complex life cycles of sage-grouse and time lags in population impacts associated with other forms of energy development make it difficult to conclude or speculate on the cumulative impacts to sage-grouse from wind energy development based on this initial research. Additional years of monitoring as well as multiple studies investigating this relationship are needed to fully understand the impacts of wind energy infrastructure on sage-grouse populations. However, the data presented from this study provide insight into the early interactions of wind energy infrastructure and sage-grouse. We determined that nest success and brood-rearing success were not statistically different between areas with and without wind energy development in the short-term. We also determined that nest success is not influenced by anthropogenic features such as turbines in the short-term. Additionally, female survival was similar among both study areas, suggesting wind energy infrastructure is not impacting female survival in the short-term; however, further analysis is needed to identify habitats with different levels of risk to better understand the impact of wind development on survival. We investigated habitat selection within both study areas. Nest and brood-rearing habitat selection were not influenced by turbines in the short-term; however, summer habitat selection occurred within habitats closer to wind turbines. Major roads were avoided in both study areas and during most of the seasons. The impact of transmission lines varied among study areas, suggesting other landscape features may be influencing selection. Lastly, we monitored occupied leks within both study areas to investigate the response of the breeding population to wind energy infrastructure. Mean lek size decreased from 2008 (pre-development) to 2010 within the altered habitat (SMH) and unaltered (SRWRA) habitat. Because the potential sphere of influence of wind turbines on sage-grouse is not known, we are not certain that sage-grouse at the SRWRA are not influenced by wind turbines at $\mathrm{SMH}$. If the potential sphere of influence does extend to sagegrouse on the SRWRA, then our assumption that the SWRWA represents a valid reference area for SMH may not be valid.

The data provided in this report should be considered preliminary and are not meant to provide a basis for forming any conclusions regarding potential impacts of wind energy development on greater sage-grouse. Although the data collected during the initial phases of this study indicate that greater sage-grouse may continue to use habitats near wind-energy facilities, research conducted on greater sage-grouse response to oil and gas development has found population declines due to oil and gas development may not occur until four or five years post-construction (Holloran 2005, Naugle et al. 2011), and results of another study of oil and gas development suggested that there is a delay of 2-10 years before measurable effects on leks manifest themselves (Harju et al. 2010). Therefore, long-term data from several geographic areas within 
the range of the sage-grouse will likely be required to adequately assess impacts of windenergy development on greater sage-grouse.

The data collected during this study were sufficient to provide information on lek locations as well as areas of relatively high use by sage-grouse during the breeding, nesting, brood-rearing, summer, fall and winter seasons at the SRWRA. Should wind energy development occur within the SRWRA at some future date, these data should be taken into consideration when designing layout of the facility to avoid or minimize impacts to greater sage-grouse.

\section{ACKNOWLEDGEMENTS}

This study was funded primarily by the wind industry, with EDP Renewables (formerly Horizon Wind Energy) being the principal source of funding. Iberdrola Renewables also contributed funding to obtain radio telemetry collars, and the Bates Hole/Shirley Basin Local Sage-Grouse Working Group paid for all flight time for the project. WEST, Inc. also received a $\$ 100,000$ grant from the U.S. Department of Energy for this study. We thank PacifiCorp for allowing access to the Seven Mile Hill facility and Burt and Kay Lynn Palm for allowing access to the Simpson Ridge study area to conduct this study.

We appreciate the assistance of Ariana Malone, Brandon Smith, Jason Herreman, and Victoria Poulton who helped capture sage-grouse for this study. Ariana Malone, Brandon Smith, Greg Leighty, and Jason Herreman assisted with relocating radio-marked sage-grouse. Scott Gamo and Mary Flanderka with the Habitat Protection Branch of the WGFD providing valuable comments on the protocol prepared for this study, as did Jack Connelly with the Idaho Fish and Game Department and Christian Hagen with the Oregon Department of Fish and Wildlife. We thank Jeffrey Beck of the University of Wyoming for providing valuable review and input throughout the study.

\section{LITERATURE CITED}

Aldridge, C. L., and M. S. Boyce. 2007. Linking occurrence and fitness to persistence: habitatbased approach for endangered greater sage-grouse. Ecological Applications 17:508526.

Beck, J. L., K. P. Reese, J. W. Connelly, and M. B. Lucia. 2006. Movements and survival of juvenile greater sage-grouse in southeastern Idaho. Wildlife Society Bulletin 34:10701078.

Beck, T. D. I., C. E. Braun. 1980. The strutting ground count: variation, traditionalism, management needs. Proceedings of the Western Association of Fish and Wildlife Agencies 60:558-566.

Boyce M. S., P. R. Vernier, S. E. Nielsen, and F. K. A. Schmiegelow. 2002. Evaluating resource selection functions. Ecological Modeling 157:281-300. 
Burnham K.P and D.R. Anderson. 2002. Model selection and Multimodel Inference: A Practical Information-Theoretic Approach: Second edition. Springer-Verlag, New York, New York, USA.

Carpenter J., C. Aldridge, and M. S. Boyce. 2010. Sage-grouse habitat selection during winter in Alberta. Journal of Wildlife Management 74:1806-1814.

Christiansen, T. 2007. Chapter 12: Sage Grouse (Centrocercus urophasianus). In: Handbook of Biological Techniques. Third edition. S. A. Tessmann, Editor. Wyoming Game and Fish Department, Cheyenne, Wyoming, USA.

Connelly, J. W. and C. E. Braun. 1997. Long-term changes in sage-grouse Centrocercus urophasianus populations in western North America. Wildlife Biology 3: 123-128.

Connelly, J. W., M.A. Schroeder, A. R. Sands, and C. E. Braun. 2000a. Guidelines to manage sage grouse populations and their habitats. Wildlife Society Bulletin 28:967-985.

Connelly J. W., K. P. Reese, R. A. Fischer, and W. L. Wakkinen. 2000b. Response of a sagegrouse breeding population to fire in southeastern Idaho. Wildlife Biology 28:90-96.

Connelly, J. W., C. A. Hagen, and M. A. Schroeder. 2011. Characteristics and dynamics of greater sage-grouse populations. In S. T. Knick and J. W. Connelly [eds.], Greater SageGrouse: Ecology and conservation of a landscape species and its habitats. Studies in Avian Biology Series. Volume 38. University of California Press, Berkeley, CA.

Crawford, J. A. and R. S. Lutz. 1985. Sage Grouse population trends in Oregon, 1941-1983. Murrelet 66:69-74.

Crawford, J. A., R. A. Olson, N. E. West, J. C. Mosley, M. A. Schroeder, T. D. Witson, R. F. Miller, M. A. Gregg, and C. S. Boyd. 2004. Ecology and management of sage-grouse and sage-grouse habitat. Journal Range Management 57:2-19.

Doherty, K. E., D. E. Naugle, B. L. Walker. 2010. Greater sage-grouse nesting habitat: The importance of managing at multiple scales. Journal of Wildlife Management 74:15441553.

Giesen, K. M., T. J. Schoenberg, and C. E. Braun. 1982. Methods for trapping sage grouse in Colorado. Wildlife Society Bulletin 10:224-231.

Gregg, M. A., J. A. Crawford, M. S. Drut, and A. K. DeLong. 1994. Vegetational cover and predation of sage grouse nests in Oregon. Journal Wildlife Management 58:162-166.

Hagen, C. A., J. W. Connelly, and M .A. Schroeder. 2007. A meta-analysis of greater sagegrouse Centrocercus urophasianus nesting and brood-rearing habitats. Wildlife Biology 13:42-50.

Harju, S. M., M. R. Dzialak, R. C. Taylor, L. D. Hayden-Wing, J. B. Winstead. 2010. Thresholds and time lags in effects of energy development on greater sage-grouse populations. Journal of Wildlife Management 74:437-448.

Holloran, M. J. 1999. Sage grouse (Centrocercus urophasianus) seasonal habitat use near Casper, Wyoming. Thesis, University of Wyoming, Laramie, USA. 
Holloran, M. J. 2005. Greater sage-grouse (Centrocercus urophasianus) population response to natural gas field development in western Wyoming. Dissertation, University of Wyoming, Laramie, USA.

Holloran, M. J. and S. H. Anderson. 2005. Spatial distribution of greater sage-grouse nests in relatively contiguous sagebrush habitats. The Condor 107:742-752.

Holloran, M. J., R. C. Kaiser, and W. A. Hubert. 2010. Yearling greater sage-grouse response to energy development in Wyoming. Journal of Wildlife Management 74:65-72.

Homer, C.G., Aldridge, C.L., Meyer, D.K., Coan, M.J., and Bowen, Z.H., 2009, Multiscale sagebrush rangeland habitat modeling in southwest Wyoming: U.S. Geological Survey Open-File Report 2008-1027, 14 p.

Homer, C.G., C.L. Aldridge, D.K. Meyer, S. Schell. 2010. Multi-Scale Remote Sensing Sagebrush Characterization with Regression Trees over Wyoming, USA; Laying a Foundation for Monitoring: International Journal of Applied Earth Observation and Geoinformation (In Review)

Johnson, C.J., S. E. Nielsen, E. H. Merrill, T. L. McDonald, M. S. Boyce. 2006. Resource selection functions based on use-availability data: Theoretical motivation and evaluation methods. Journal of Wildlife Management 70(2):347-357.

Johnson, G.D. 2009. Greater sage-grouse technical report, Mountain States Transmission Intertie Project. Unpublished report prepared for PBS\&J by Western EcoSystems Technology, Inc. (WEST), Cheyenne, WY.

Johnson, G.D. and M.J. Holloran. 2010. Greater Sage-Grouse and Wind Energy Development: A Review of the Issues. Renewable Northwest Project, Portland, Oregon.

Johnson, G.D. and S.E. Stephens. 2011. Wind Power and Bio Fuels: A Green Dilemma for Wildlife Conservation. Pages 131-155 In: Energy Development and Wildlife Conservation in Western North America. D. E. Naugle, Ed., Island Press, Washington, D.C.

Johnson, G.D. and E. Young. 2011. Greater prairie chicken lek surveys, Elk River Wind Farm, Butler County, Kansas: 2003-2011. Unpublished report prepared for Iberdrola Renewables by WEST, Inc., Cheyenne, WY.

Johnson, G.D., W. Erickson and E. Young. 2009. Greater prairie chicken lek surveys, Elk River Wind Farm, Butler County, Kansas. Unpublished report prepared for Iberdrola Renewables by WEST, Inc., Cheyenne, WY.

Kernohan, B. J., R. A. Gitzen, and J. J. Millspaugh. 2001. Analysis of animal space use and movements. Pages125-166 in J. J. Millspaugh and J. M. Marzluff, Editors. Radio tracking and animal populations. Academic Press, San Diego, California.

Kirol, C. P., J. L. Beck, J. B. Dinkins, and M. R. Conover. 2012. Micohabitiat selection for nesting and brood-rearing by the greater sage-grouse in xeric big sagebrush. The Condor 114:75-89. 
Kolada, E. J., M. L. Casazza, and J. S. Sedinger. 2009. Ecological factors influencing nest survival of greater sage-grouse in Mono County, California. Journal of Wildlife Management 73:1341-1347.

Manes, R., S. Harmon, B. Obermeyer, and R. Applegate. 2002. Wind Energy and Wildlife: An Attempt at Pragmatism. Special Report of the Wildlife Management Institute. October 2002. 11 pp.

Manly, B. F. J., L. L. McDonald, D. L. Thomas, T. L. McDonald, and W. P. Erickson. 2002. Resource selection by animals: statistical design and analysis for field studies. Chapman and Hall, London, UK.

McDonald, T. L., B. F. Manly, R. M. Nielson, L. V. Diller. 2006. Discrete-choice modeling in wildlife studies exemplified by northern spotted owl nighttime habitat selection. Journal of Wildlife Management 70:375-383.

National Wind Coordinating Committee (NWCC). 2004. Wind Turbine Interactions with Birds and Bats: A Summary of Research Results and Remaining Questions. Fact Sheet, Second Edition. November 2004. http://www.nationalwind.org/publications/default.htm

Naugle, D. E., K. E. Doherty, B. L. Walker, M. J. Holloran, and H. E. Copeland. 2011. Energy development and greater sage-grouse. In S. T. Knick and J. W. Connelly [eds.], Greater Sage-Grouse: Ecology and conservation of a landscape species and its habitats. Studies in Avian Biology Series. Volume 38. University of California Press, Berkeley, CA.

Nebraska Game and Parks Commission (NGPC). 2009. Location of sharp-tailed grouse and greater prairie-chicken display grounds in relation to NPPD Ainsworth Wind Energy Facility: 2006-2009. NGPC, Lincoln, Nebraska, USA.

Pollock, K. H., S. R. Winterstein, C. M. Bunck, and P. D. Curtis. 1989. Survival analysis in telemetry studies: The staggered entry design. Journal of Wildlife Management 53:7-15.

Pruett, C. L., M. A. Patten, D. H. Wolfe. 2009a. It's not easy being green: Wind energy and a declining grassland bird. Bioscience 59: 257-262.

Pruett, C. L., M. A. Patten, D. H. Wolfe. 2009b. Avoidance behavior by prairie grouse: Implications for development of wind energy. Conservation Biology 23:1253-1259.

Rebholz, J. L. 2007. Influence of habitat characteristics on greater sage-grouse reproductive success in the Montana Mountains, Nevada. Thesis, Oregon State University, Corvallis, USA.

Robbins, M. B., A. T. Peterson, and M. A. Ortega-Huerta. 2002. Major Negative impacts of early intensive cattle stocking on tallgrass prairie: The case of the greater prairie-chicken (Tympanuchus cupido). North American Birds 56(2):239-244.

Robel, R. J., J. A. Harrington Jr., C. A. Hagen, J. C. Pitman, and R. R. Reker. 2004. Effect of energy development and human activity on the use of sand sagebrush habitat by Lesser Prairie-Chickens in southwestern Kansas. Transactions of the North American Wildlife and Natural Resources Conference 69:251-266. 
Rotella, J. J., S. J., Dinsmore, and T. L. Shaffer. 2004. Modeling nest-survival data: a comparison of recently developed methods that can be implemented in MARK and SAS. Animal Biodiversity and Conservation 27: 187-205.

Sappington, M. J., K. M. Longshore, and D. B. Thompson. 2005. Quantifying landscape ruggedness for animal habitat analysis: A case study using bighorn sheep in the Mojave Desert. Journal of Wildlife Management 71:1419-1426.

Schroeder, M.A., J.R. Young, and C.E. Braun. 1999. Sage grouse (Centrocercus urophasianus). Page 28 in A. Pool and F. Gill, edition. The Birds of North America. The Birds of North America, Inc, Philadelphia, Pennsylvania, USA.

Thomas, D. L., and E. J. Taylor. 2006. Study designs and tests for comparing resource use and availability II. Journal of Wildlife Management. 70:324-336.

Thompson, K. M, M. J. Holloran, S. J. Slater, J. L. Kuipers, and S. H. Anderson. 2006. Early brood-rearing habitat use and productivity of Greater Sage-Grouse in Wyoming. Western North American Naturalist. 66:332-342.

Toepfer, J.E. and W.L. Vodehnal. 2009. Greater prairie chickens: Grasslands and vertical structures. Presentation at the 28th Meeting of the Prairie Grouse Technical Council, Portales, New Mexico, October 5-8, 2009.

US Fish and Wildlife Service (USFWS). 2003. Interim Guidelines to Avoid and Minimize Wildlife Impacts from Wind Turbines. May 2003. http://www.fws.gov/habitatconservation/wind.pdf

US Fish and Wildlife Service (USFWS). 2004. Prairie Grouse Leks and Wind Turbines: US Fish and Wildlife Service Justification for a 5-Mile Buffer from Leks; Additional Grassland Songbird Recommendations. An unpublished briefing paper.

US Geological Survey (USGS) National Land Cover Database (NLCD). 2001. Land Use/Land Cover NLCD Data. USGS Headquarters, USGS National Center. Reston, Virginia.

Wakkinen, W. L., K. P. Reese, J. W. Connelly, and R. A. Fischer. 1992. An improved spotlighting technique for capturing sage grouse. Wildlife Society Bulletin 20:425-426.

Walker, B. L. 2008. Greater sage-grouse response to coal-bed natural gas development and West Nile virus in the Powder River Basin, Montana and Wyoming, USA. Dissertation, University of Montana, Missoula, USA.

Walker, B. L., D. E. Naugle, and K. E. Doherty. 2007. Greater sage-grouse population response to energy development and habitat loss. Journal of Wildlife Management 71:2644-2654.

Wallestad, R.O. and D.B. Pyrah. 1974. Movement and nesting of sage grouse females in central Montana. Journal of Wildlife Management 38:630-633.

Walsh, D. P., C. G. White, T. E. Remington, and D. C. Bowden. 2004. Evaluation of the lekcount index for greater sage-grouse. Wildlife Society Bulletin 32:56-68.

Worton, B. J. 1989. Kernel methods for estimating the utilization distribution in home-range studies. Ecology 70:164-168. 
Zeiler, H.P. and V. Grünschachner-Berger. 2009. Impact of wind power plants on black grouse, Lyrurus tetrix in Alpine regions. Folia Zoologica 58:173-182. 